UNIVERSIDADE DE SÃO PAULO

FACULDADE DE FILOSOFIA CIÊNCIAS E LETRAS

DEPARTAMENTO DE LETRAS CLÁSSICAS E VERNÁCULAS

ÁREA DE FILOLOGIA E LÍNGUA PORTUGUESA

PAULA DE FREITAS DENARI

A realização do objeto indireto nas redações dos alunos de Ensino Fundamental

VERSÃO CORRIGIDA 
FACULDADE DE FILOSOFIA CIÊNCIAS E LETRAS

DEPARTAMENTO DE LETRAS CLÁSSICAS E VERNÁCULAS

ÁREA DE FILOLOGIA E LÍNGUA PORTUGUESA

\author{
PAULA DE FREITAS DENARI
}

\title{
A realização do objeto indireto nas redações dos alunos de Ensino Fundamental
}

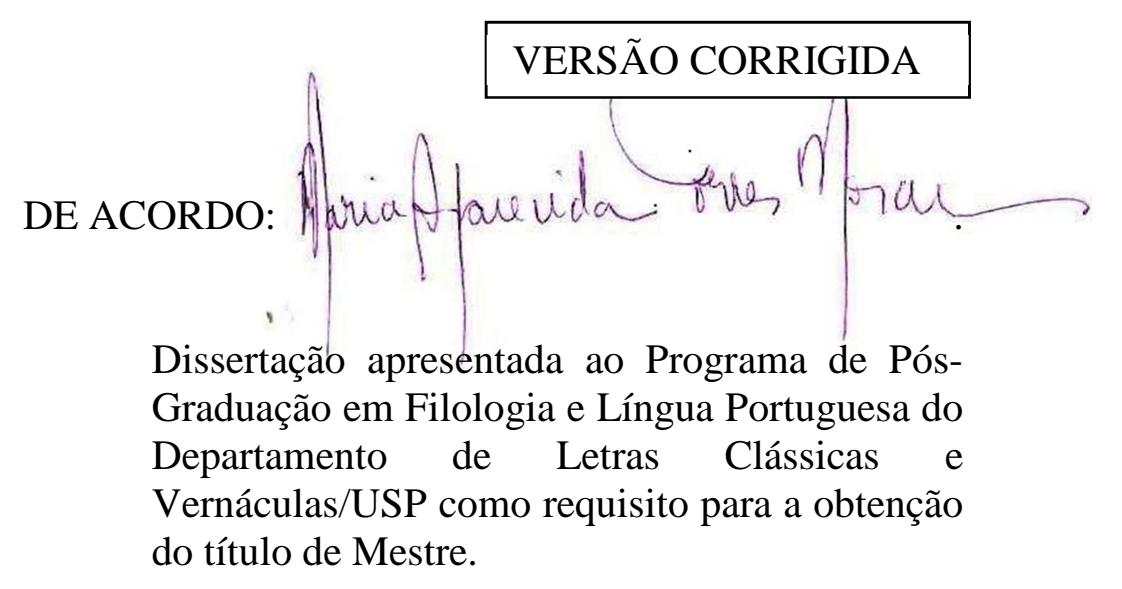

Orientadora: Prof ${ }^{\mathrm{a}}$. Dr ${ }^{\mathrm{a}}$. Maria Aparecida C. R. Torres Morais 
Nome: DENARI, Paula de Freitas .

Título: A realização do objeto indireto nas redações dos alunos de Ensino Fundamental.

Dissertação apresentada à Faculdade de Filosofia Ciências e Letras da Universidade de São Paulo para obtenção do título de Mestre em Letras

Aprovado em:

Banca Examinadora

Presidente: Prof $^{a}$. Dr ${ }^{a}$. Maria Aparecida C. R. Torres Morais Instituição: USP

Titular: Prof ${ }^{\circ}$. Dr Emílio Gozze Paggotto

Instituição: UNICAMP

Titular: Prof ${ }^{\mathrm{a}}$. Dr ${ }^{\mathrm{a}}$. Maria Inês Batista Campos

Instituição: USP

Suplente: Prof ${ }^{a}$. Dr ${ }^{\mathrm{a}}$. Rosane de Andrade Berlinck

Instituição: UNESP - Araraquara

Suplente: Prof ${ }^{a}$. Dr ${ }^{a}$. Maria Lúcia da Cunha Victório de Oliveira Andrade Instituição: USP

Suplente: Prof ${ }^{a}$. Dr ${ }^{\mathrm{a}}$. Maria Célia Pereira Lima-Hernandes Instituição: USP

São Paulo

2013 


\section{Agradecimentos}

No dia 17 de maio, quando a professora Cida Torres disse "sim" em minha entrevista para ingresso no programa de Mestrado da Universidade de São Paulo, eu não imaginava como minha vida mudaria, que meus finais de semana iriam acabar, que minhas leituras seriam alucinadas e que o corpo sofreria as consequências desse bombardeio de estudo. No entanto, aquele "sim" a uma aluna oriunda de uma universidade particular e sem o menor conhecimento de Gramática Gerativa, foi a oportunidade para um universo se abrir e uma nova professora surgir em sala de aula. Por isso, agradeço à professora Maria Aparecida Torres Morais por cada dia de convivência, cada orientação, cada palavra de carinho. Nunca terei palavras para retribuir sua generosidade. Obrigada por acreditar em mim.

Às professoras Márcia Santos Duarte de Oliveira e Maria Inês Batista Campos pelas considerações na banca de qualificação.

Aos professores das disciplinas assistidas na pós-graduação Prof ${ }^{a}$ Maria Célia Pereira Lima Hernandes e Prof ${ }^{\circ}$ Emílio Gozze Pagotto que deram excelentes sugestões para o meu projeto.

Às professoras Sônia Firveda Gomes e Kátia Rua por me fornecerem as redações que serviram de base para este estudo.

Às professoras Alessandra Dias Marques e Daniela de Salvi Panchorra pelo auxílio com a língua inglesa.

À direção do Liceu Santista que em nenhum momento negou informações utilizadas nessa pesquisa. Em especial, à Alcielle Santos, minha coordenadora e incentivadora, que cobriu minhas faltas e falhas ao longo de um ano tão conturbado, desculpe-me por diários não entregues, provas atrasadas e faltas em reuniões. Sem sua ajuda esse período seria bem mais difícil. Também não poderia deixar de agradecer aos professores que convivem diariamente comigo e suportaram-me nesses últimos anos, é um orgulho fazer parte dessa equipe.

À direção e coordenação do Colégio do Carmo; primeiro, por me fornecerem as bases educacionais ao longo de doze anos como aluna, e hoje, como professora, sinto grande honra em retribuir o aprendizado recebido.

À Elita Cezar Argemon e Ewa Danuta Denari, por me apresentarem ao universo da pesquisa acadêmica.

Meu agradecimento mais emocionado à minha mãe, que me esperou todos os dias com a comida pronta no fogão, preocupada enquanto eu voltava de São Paulo. Perdoe-me o mau- 
humor e minhas ausências nesses últimos meses, perdoe-me, ainda, pelas mágoas causadas e palavras duras. Te amo. Você sempre será minha inspiração, meu alicerce. Obrigada por ser minha mãe.

Ao meu pai, que trabalhou muito para que eu tivesse acesso a uma educação de qualidade. A vida tomou caminhos tortuosos, mas sempre reconhecerei em mim a obstinação pelo trabalho, o senso de ética e responsabilidade herdados de ti. Obrigada e perdão.

Ao André, meu amor e companheiro, por aceitar dividir-me com esta pesquisa, por apoiar-me incondicionalmente e por ficar ao meu lado, mesmo quieto, enquanto eu passava nossos finais de semana em frente ao computador. Seu orgulho por mim e seu amor me fazem uma pessoa melhor.

A minha irmã, simplesmente por estar presente na minha vida e ter me dado meus sobrinhos: meu loiro e minha princesa, minha vida ficou muito mais feliz depois que vocês chegaram.

A todos os familiares e amigos que ouviram "não" aos convites para saídas e passeios.

E a todos os meus alunos, por me permitirem continuar com o espírito sempre jovem e me sentir renovada a cada ano letivo...

Cada linha dessa pesquisa é dedicada a cada um de vocês. Meu muito obrigada. 


\section{RESUMO}

DENARI, Paula de Freitas. A REALIZAÇÃO DO OBJETO INDIRETO NAS REDAÇÕES DOS ALUNOS DE ENSINO FUNDAMENTAL. 2013. Dissertação (Mestrado) - Faculdade de Filosofia, Letras e Ciências Humanas da Universidade de São Paulo, São Paulo, 2007.

Estudos já apontaram para o crescente desaparecimento do pronome clítico dativo de terceira pessoa e para a substituição da preposição $a$ pela preposição para na introdução de objeto indireto (OI) lexical no português brasileiro (PB). Tal fenômeno é identificado a partir de dados do século XIX e esses estudos, em sua maioria, partem de dados da linguagem adulta, sendo que poucos tratam deste fenômeno no âmbito escolar.

Esta dissertação discute as estratégias de preenchimento do dativo no português brasileiro (PB), caracterizado pela gramática tradicional de objeto indireto, com o uso das preposições $a$ e para, sob a forma nula e de pronome (lhe/lhes) em redações de alunos de $6^{\circ}$. ao $9^{\circ}$. ano de um colégio público e um colégio particular, da cidade de Santos.

Nosso objetivo é verificar o papel da escola na recuperação das formas de prestígio e confrontar os dados encontrados com os trabalhos de Torres Morais e Berlinck (2006), Freire (2011) e Dutra (2003), os quais apontam três estratégias inovadoras: a substituição da preposição a por para, a perda progressiva dos clíticos de $3^{\text {a }}$ pessoa (lhe/lhes), que são substituídos pela forma preposicionada (a eleleles, a ela/elas), e o aumento das formas nulas.

Acima disso, espera-se, no confronto entre as produções textuais produzidas pelos alunos da escola pública e particular, indagar se há diferença na gramática internalizada de alunos que receberam diferentes estímulos linguísticos.

Palavras-chave: Dativo. Princípios e Parâmetros. Objeto Indireto. 


\section{ABSTRACT}

DENARI, Paula de Freitas. THE USE OF DE INDIRECT OBJECT IN STUDENT'S COMPOSITIONS IN THE SECONDARY SCHOOL. 2013. Dissertação (Mestrado) Faculdade de Filosofia, Letras e Ciências Humanas da Universidade de São Paulo, São Paulo, 2007.

Several studies have pointed at the increasing disappearance of the pronoun dative clitic third person and for the replacement of the preposition "a" for "para" for the introduction of indirect object (OI) lexical in Brazilian Portuguese (PB). This phenomenon is identified from data of the nineteenth century and these studies, mostly originated from data of adult language, and few deal with this phenomenon in the school environment.

This essay discusses strategies for fulfilling the dative complement in Brazilian Portuguese (BP), characterized by traditional grammar as indirect object, with the usage of the prepositions " $a$ " and "para" and its usage as a null form and a pronoun ("lhe/lhes") in 6th to 9th grade students' compositions within a public and a private school, in Santos.

Our aim is to verify the school's role in the rescuing of the forms of prestige and comparing the data found in the works of Torres Morais and Berlinck (2006), Freire (2011), and Dutra (2003), which point at three innovative strategies: the replacement of the preposition " $a$ " for "para", the progressive loss of 3rd person clitics ("Ihe/lhes"), which are replaced for the prepositional form ("a eleleles", "a ela/elas"), and the increasing of null forms.

Moreover, it is attempted to question if there is a difference, in the grammar internalized by students from public and private school who received different linguistic stimuli.

Keywords: Dative. Principles and Parameters. Indirect Object. 


\section{SUMÁRIO}

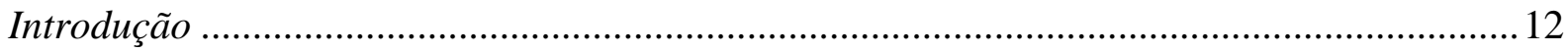

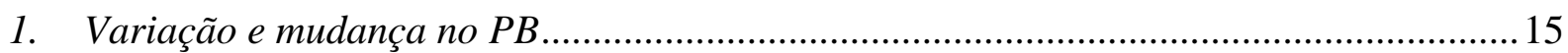

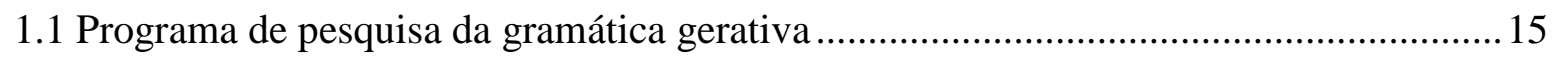

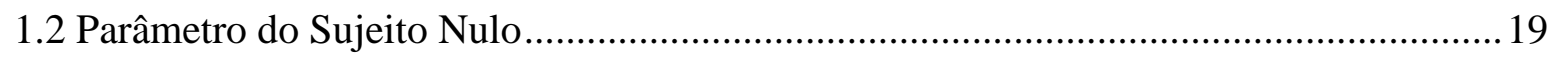

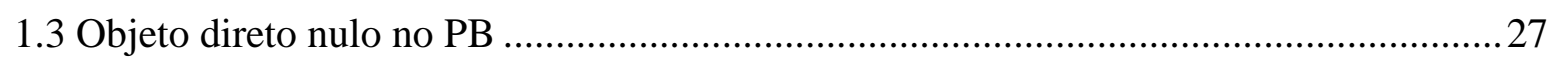

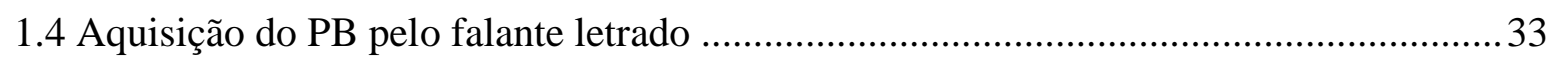

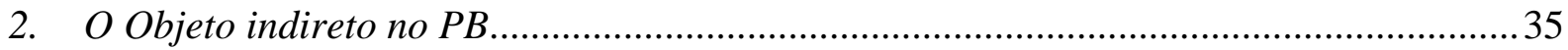

2.1. A definição dos verbos bitransitivos de acordo com a Gramática Tradicional .............37

2.2. A descrição do PB do OI nos trabalhos acadêmicos ................................................ 41

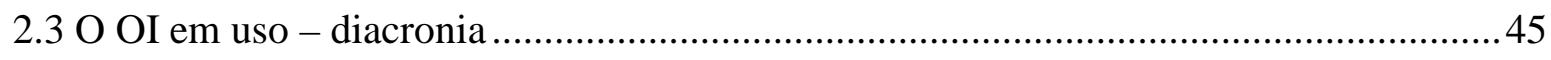

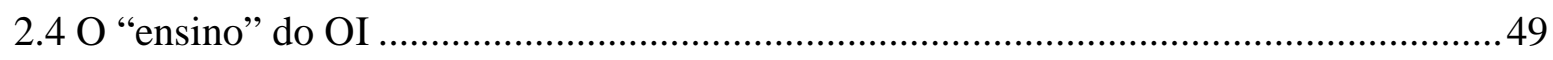

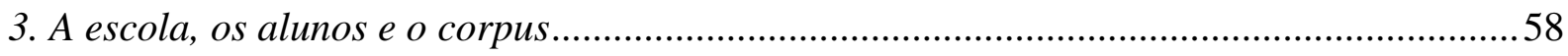

3.1. Os Parâmetros Curriculares Nacionais ..............................................................................59

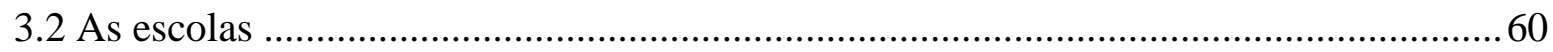

3.3 Comparação entre as identidades assumidas pelas escolas ........................................65

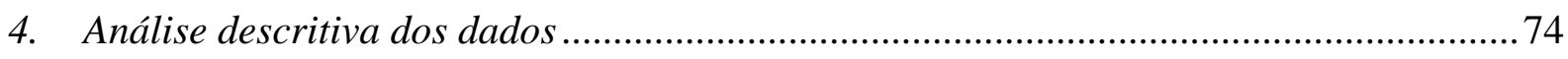

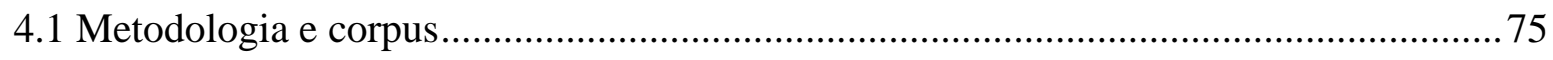

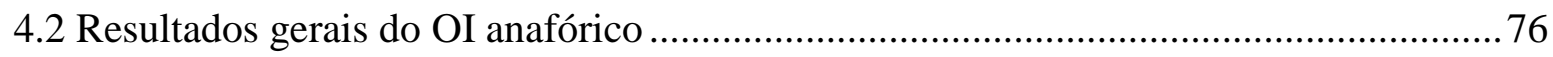

4.3 A realização do OI lexical - uso de a x para.................................................................91

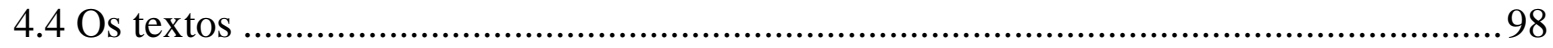

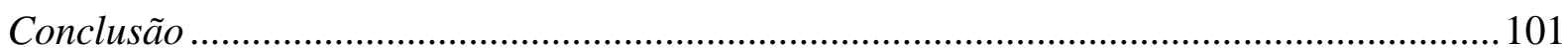

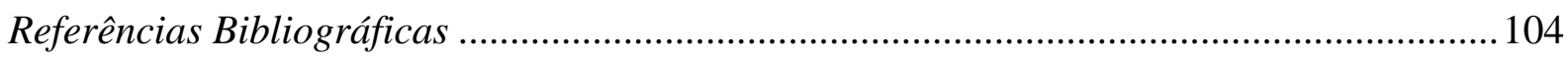

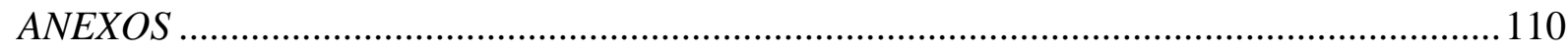




\section{Índice de tabelas}

Tabela 1- Paradigma flexional do português segundo a tradição escolar

Tabela 2 - Redução do paradigma flexional do PB

Tabela 3 - Realização do objeto direto de $3^{\text {a }}$ pessoa em quatro diferentes cidades brasileiras

Tabela 4 - A categorização do OI de acordo com Mateus (2003), Câmara Junior (2002),

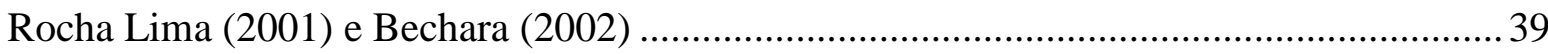

Tabela 5 - OI anafórico na fala de curitibanos - Percentuais e número de ocorrências....... 47

Tabela 6 - Uso da preposição a e para na realização do OI .................................................. 48

Tabela 7 - Função dativa na língua oral: distribuição dos dados segundo a variante usada

Tabela 8 - Função dativa na língua escrita: distribuição dos dados segundo a variante usada.

Tabela 9 - Função dativa: distribuição dos dados computados segundo a variante usada ...52

Tabela 10 - Forma de preenchimento do OI - Atividade mais formal ................................54

Tabela 11 - Forma de preenchimento do OI - Atividade mais informal .............................55

Tabela 12 - Componentes curriculares da Escola Pública e Particular..................................67

Tabela 13 - Escola Pública - Dados de 2010 _.......................................................................68

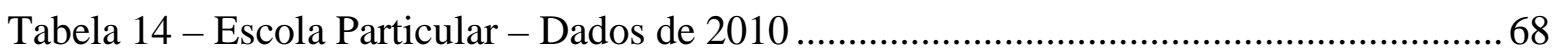

Tabela 15 - Taxa de retenção crítica (> 20\%) por ano em Língua Portuguesa da Escola

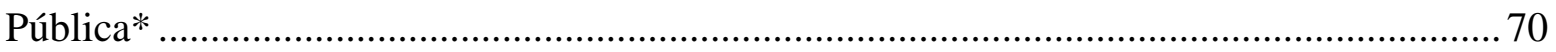

Tabela 16 - Relatório de Distorção de Idade ( $6^{\circ}$ ao $9^{\circ}$ ano) na escola pública - ano de

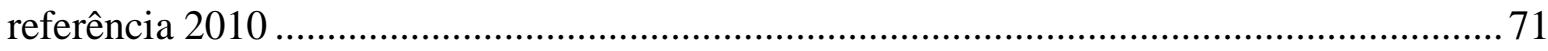

Tabela 17 - Escolaridade dos pais dos alunos de $9^{\circ}$ ano da UME Edméa Ladevig .............. 72

Tabela 18 - Escolaridade dos pais dos alunos de $9^{\circ}$ ano do Liceu Santista .......................... 72

Tabela 19 - Realização do OI anafórico por ano escolar - Escola Pública .......................... 77

Tabela 20 - Realização do OI anafórico por ano escolar - Escola Particular ........................77

Tabela 21 - Realização do OI nulo no EF2 - Atividade mais monitorada ............................ 82

Tabela 22 - Realização do OI nulo no EF2 - Escola Pública e Particular............................ 82

Tabela 23 - Realização do OI nulo no EF2 - Atividade menos monitorada ....................... 83

Tabela 24 - Realização do OI nulo, por ano escolar na escola pública e particular ..............83

Tabela 25 - Realização do pronome clítico, por ano escolar na escola pública..................... 84 
Tabela 26 - Realização do pronome clítico, por ano escolar na escola particular 84

Tabela 27 - Realização de clítico dativo de terceira pessoa de acordo com o tipo verbal no $7^{\circ}$ ano da Escola Pública .85

Tabela 28 - Realização de OI nulo anafórico de acordo com o tipo verbal. 88

Tabela 29 - Porcentagem de realização de OI nulo anafórico de acordo com o tipo verbal em relação às outras variantes 89

Tabela 30 - Função dativa: distribuição das variantes segundo o tipo de verbo 90

Tabela 31 - Função dativa: distribuição das variantes segundo o tipo de verbo 91

Tabela 32 - Preenchimento de OI não anafórico realizado por SN precedido por preposição a ou para divido por ano escolar na Escola Particular.

Tabela 33 - Preenchimento de OI não anafórico realização por SN precedido por preposição a ou para - Escola Pública. 93

Tabela 34 - Realização do OI lexical por série escolar na Escola Particular. .96

Tabela 35 - Realização do OI lexical por série escolar na Escola Pública .96 


\section{Índice de gráficos}

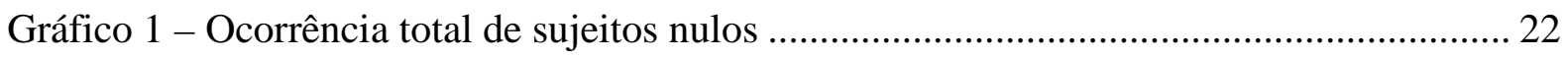

Gráfico 2 - Sujeito nulo na aquisição do inglês e do PB ........................................................ 24

Gráfico 3 - Objetos nulos na aquisição do PB e do PE.............................................................. 28

Gráfico 4 - A realização do objeto direto anafórico de acordo com o grau de escolaridade do

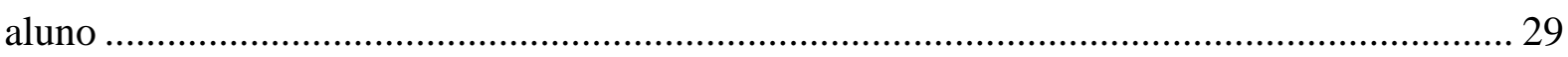

Gráfico 5 - Variantes de OI de $3^{\mathrm{a}}$. pessoa no PB dos séculos XVIII e XIX .......................... 46

Gráfico 6 - Uso da preposição a e para na realização do OI.................................................... 49

Gráfico 7 - Variantes em função dativa no PB, segundo o continuum oralidade - letramento

Gráfico 8 - Função dativa - distribuição das variantes segundo a variedade do português .... 52

Gráfico 9 - Distribuição das variantes clítico dativo em um continuum oralidade-letramento

Gráfico 10 - Aumento do PIB - per capita (R\$) na cidade de Santos ................................. 62

Gráfico 11 - Retenção de alunos na escola pública e particular em porcentagem.................. 69

Gráfico 12 - Realização da forma plena e nula do OI, de acordo com o ano escolar na escola

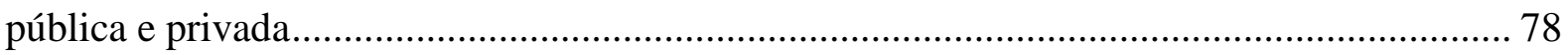

Gráfico 13 - Uso de verbos de transferência verbal e perceptual em ocorrências de OI anafórico

Gráfico 14 - Realizações do OI anafórico nos verbos de transferência material e verbal na escola pública e particular

Gráfico 15 - Preenchimento de OI não anafórico realizado por SN precedido por preposição a ou para em verbos de transferência verbal e perceptual.

Gráfico 16 - Uso de SN precedido de preposição a ou para de acordo com a série escolar e o tipo de verbo 


\section{Introdução}

Há algumas décadas, estudos sobre o português brasileiro (PB) assinalam fenômenos de mudança em progresso responsáveis por um distanciamento ainda maior entre as formas gramaticais de prestígio, preconizadas nos compêndios normativos, e o emprego efetivo de formas inovadoras por parte do usuário brasileiro. Entre esses casos inovadores encontram-se as diferentes estratégias na realização dos sujeitos pronominais e complementos verbais, a saber, objetos diretos e indiretos.

Em relação ao objeto indireto $(\mathrm{OI})$ de $3^{\mathrm{a}}$ pessoa, na variante culta do $\mathrm{PB}$, os trabalhos de Berlinck (2005), Gomes (2003), Bispo (2004), Freire (2000; 2005; 2011), Torres Morais \& Berlinck (2006; 2007; 2009), Torres Morais \& Salles (2010), Campos (2011) e outros, exibem resultados quantitativos, os quais revelam a gradativa implementação, ao longo do tempo, de três estratégias, no contexto dos verbos bitransitivos de transferência e movimento, entre eles, dar, enviar, mostrar, oferecer, comprar, dizer, perguntar etc. (cf. Berlink, 1996). São elas:

(1) substituição da preposição $a$ por para;

a. O Pedro deu uma bicicleta ao filho

b. O Pedro deu uma bicicleta para o filho

(2) substituição dos clíticos de $3^{\text {a }}$ pessoa (lhe/lhes), substituídos pelas formas preposicionadas (a/para eleleles, a/para ela/elas);

a. O Pedro deu-lhe uma bicicleta

b. O Pedro deu uma bicicleta a ele/para ele

(3) substituição dos clíticos por formas nulas fonologicamente

a. O Pedro foi ao casamento do João e levou-lhe um belo presente

b. O Pedro foi ao casamento do João e levou [ $\emptyset]$ um belo presente

As estratégias inovadoras, ausentes na gramática do português europeu (PE), mostram os diferentes rumos que o PB toma na expressão do OI.

Observa-se ainda a intensificação do uso do pronome lhe em referência à segunda pessoa, seja em função acusativa - objeto direto -, seja em função dativa - objeto indireto (Ramos, 1999 e Freire, 2000). Tais dados reforçam a ideia de que as formas pronominais 
lhe/lhes estariam passando por um processo de especialização, sendo utilizadas em alusão apenas à segunda pessoa na função dativa e acusativa.

(4) a. Paulo, eu lhe dou o dinheiro amanhã, sem falta.

b. Como combinamos, eu the encontro amanhã

O principal objetivo dessa dissertação é descrever as estratégias de realização do objeto indireto de $3^{\mathrm{a}}$ pessoa, em redações de alunos do Ensino Fundamental. Seria de se esperar que, nesta etapa da escolaridade, pelo menos a produção escrita dos estudantes estaria manifestando um bom percentual de formas clíticas, e emprego da preposição $a$, ambos incorporados à sua prática linguística. Por que isto seria de se esperar? Por uma simples razão: são essas as formas reconhecidas na caracterização do OI na maioria dos compêndios gramaticais, os quais tomam como base os usos lusitanos. De fato, as formas clíticas lhe/lhes e a preposição a como introdutora do OI de $3^{\text {a }}$ pessoa são muito produtivas no $\mathrm{PE}$, independentemente da escolaridade. Ou seja, trata-se de formas da gramática nuclear, adquiridas na fase da aquisição da língua materna.

Ora, como sabemos, a prática pedagógica toma como modelo de variante culta os padrões definidos nas gramáticas normativas. Parece haver um total desconhecimento das variações atestadas na língua falada e escrita dos usuários cultos do PB.

No entanto, apesar dessa expectativa, a hipótese que buscamos confirmar nesta dissertação é a de que a escola não terá êxito na retomada das formas de prestígio na produção escrita dos alunos. Espera-se mostrar uma baixa frequência em suas realizações, sendo elas suplantadas pelas formas inovadoras. A baixa frequência das formas de prestígio também foi confirmada em vários estudos anteriores que trataram a variação linguística nos textos escolares.

Tomando como base os pressupostos da Teoria dos Princípios e Parâmetros, consideraremos ainda uma segunda hipótese: a de que o PE e PB instanciam duas gramáticas distintas em termos de Língua-I (cf. Chomsky, 1986). Esta hipótese foi defendida por Galves (1998), com base em estudos de caso, incluindo os que tratam da variação na sintaxe pronominal.

A dissertação organiza-se da seguinte forma.

$\mathrm{Na}$ seção1, do capítulo 1, trazemos alguns aspectos da Teoria dos Princípios e Parâmetros, com base em Chomsky (1981; 1986; 1988). Tal perspectiva será relevante para entendermos os fenômenos de variação e mudança que caracterizam o PB, em dois aspectos. 
O primeiro, conhecido como Parâmetro do Sujeito Nulo, será tratado na seção 2. O segundo, denominado Parâmetro do Objeto Direto Nulo, será apresentado na seção 3. Concluímos o capítulo com uma reflexão sobre a gramática do letrado, tal como discutida por Kato (2005) e Kato, Cyrino \& Correia (2009).

O capítulo 2 trata do objeto indireto. Na seção 1, focalizamos as definições dessa categoria gramatical em alguns gramáticos, com o objetivo de mostrar que não há consenso entre eles quanto a uma precisa identificação do OI. Na seção 2, damos voz aos linguistas no tratamento elaborado para dar conta do OI. Em particular, destacamos as formas de realização do objeto indireto no $\mathrm{PB}$, os quais representam aspectos inovadores.

Em contraponto à discussão gramatical, o capítulo 3 traz uma descrição do ambiente familiar e social dos alunos da escola pública e privada que nos forneceram as redações utilizadas nesta pesquisa. Em particular, desenhamos um mapa da realidade familiar e econômica desses alunos. Vários estudos têm mostrado que a escola leva anos no resgate das formas que não mais pertencem ao vernáculo (cf. Freire, 2011). Sabendo que as crianças recebem em casa diferentes estímulos linguísticos, de acordo com a escolaridade e profissão de seus pais, nosso objetivo foi observar se as formas de prestígio na realização do OI, a saber, os clíticos e a preposição $a$, são adquiridas de forma distinta. Achamos ainda interessante apontar aspectos da visão veiculada nos Parâmetros Curriculares Nacionais em relação ao ensino da Língua Portuguesa na escola, especificamente no Ensino Fundamental.

Por fim, no capítulo 4, ao analisar o conjunto das redações selecionadas, referentes às séries do ensino fundamental 2, baseamo-nos nas seguintes questões: (i) quanto a escola resgata das formas de prestígio com base no ensino formal? (ii) quais as formas de realização do OI mais frequentes nos textos dos alunos?

O cerne do capítulo é, pois, a apresentação dos resultados encontrados e o que essas ocorrências revelam sobre a força cognitiva e funcional da gramática núcleo, adquirida na fase da aquisição da língua materna, em oposição às formas aprendidas como L2. Espera-se ainda obter resultados que mostrem algum efeito do ambiente social e familiar numa maior assimilação dos padrões cultos via escolaridade. 


\section{Variação e mudança no PB}

\subsection{Programa de pesquisa da gramática gerativa}

A partir da segunda metade do século XX, a pesquisa gramatical recebeu uma profunda reestruturação na perspectiva de investigação proposta por Noam Chomsky, colocando a Linguística entre as ciências cognitivas. Agora o objeto central da investigação linguística é a Faculdade da Linguagem (FL), entendida como um órgão mental, um componente inato da mente humana, que direciona a aquisição do conhecimento linguístico e está envolvida nos aspectos do uso, tal como a produção e compreensão das sentenças. Os linguistas que se identificam com este tipo de perspectiva arregaçam as mangas para o compromisso com um programa de pesquisa, engajado em dar conta das seguintes questões:

1) $\mathrm{O}$ que temos representado em nossa mente, quando somos capazes de falar e entender uma língua (português, japonês, inglês, árabe)?

2) Como este conhecimento é adquirido?

3) Como este conhecimento é posto em uso na fala (e escrita)?

4) Quais são os mecanismos físicos envolvidos na representação, aquisição e uso deste conhecimento?

Assim, o termo gramática gerativa foi cunhado para se referir a uma concepção muito particular sobre as línguas humanas. Gramática não tem aqui o significado tradicional de conjunto de regras que descrevem uma determinada língua, ao contrário, diz respeito a um conjunto de regras/princípios representados na mente/cérebro do falante nativo. Está relacionado ao que Chomsky (1986) denomina Língua-I(nternalizada), um sistema computacional de um tipo particular que proporciona representações estruturais às expressões linguísticas. Este sistema é altamente complexo e sofisticado, determinado pela natureza da mente/cérebro.

Chomsky tem reafirmado constantemente que a Língua-I, também conhecida como competência linguística, é um objeto natural, um fenômeno individual. Não é um fenômeno social. Por sua vez, a Língua-E(xternalizada) refere-se ao desempenho linguístico, que pode ser definido nos seguintes termos: conjunto de enunciados, ou seja, uso linguístico em situações concretas, e não reflete diretamente a competência, porque esta pode ser afetada por 
fatores de natureza muito diversa. Daí se falar em um falante-ouvinte ideal, idealização que se refere à competência linguística não afetada pelos fatores externos. As evidências para descrever a competência são, porém, indiretas, estão nos dados da Língua-E.

$\mathrm{O}$ adjetivo gerativa, por sua vez, refere-se ao fato de que um conjunto finito de regras/princípios pode gerar um conjunto infinito de sentenças gramaticais. De fato, nenhuma língua tem um número $\mathrm{x}$ ou y de sentenças prontas, que o falante vai usando durante o seu desempenho linguístico. O falante sempre pode produzir novas sentenças, e estar exposto a outras, que ainda não tinha ouvido. Todas, no entanto, se conformam à gramática internalizada em sua mente. Ou seja, todas serão gramaticalmente "corretas" neste sentido.

A partir de Chomsky (1981) o estado inicial da FL, também denominada Gramática Universal (GU), é caracterizado como um conjunto de princípios e parâmetros. A aquisição da linguagem consiste basicamente em fixar os valores das opções paramétricas, na base dos dados disponíveis às crianças. Portanto, embora suponha o dado como "input", ou estímulo, este modelo não é comportamental, não se baseia em estímulo-resposta, ou seja, em uma dinâmica em que o cérebro é uma tábula rasa, e os estímulos é que vão determinando e construindo as respostas possíveis.

Portanto, pode-se dizer que os pesquisadores chomskyanos têm uma jornada dupla de trabalho. Primeiro, precisam caracterizar adequadamente o estado inicial. Pelo que se pode depreender da literatura consultada, a tarefa de formular princípios e parâmetros é um grande desafio. Em segundo lugar, precisam caracterizar a competência linguística, a Língua-I, objetivo este que está no $1^{\circ}$ item do programa de pesquisa. Nos pressupostos da Teoria dos Princípios e Parâmetros, gramáticas constituem o conhecimento particular que resulta quando os valores paramétricos são fixados.

A coisa se complica um pouco mais, porque é feita uma distinção importante entre descrição e explicação. Teorias alcançam uma adequação descritiva quando caracterizam a competência linguística dos falantes nativos, o conhecimento interiorizado na mente destes falantes. A tarefa agora é construir a gramática/teoria de uma língua particular. "It is the task of describing a real object of the real world, the language that is represented in the mind/brain of the mature speaker of the language”. (Chomsky, 1988, p.60)

Por outro lado, teorias alcançam adequação explicativa, quando apresentam soluções para o problema lógico da aquisição da linguagem, formulado nos seguintes termos: como as crianças podem alcançar o domínio de sua língua materna, com base na exposição a dados linguísticos? Para responder a esta questão, vejamos o esquema abaixo. 
Dados $\rightarrow$ Faculdade da Linguagem $\rightarrow$ Língua-I $\rightarrow$ Expressões Estruturadas

A segunda questão do programa de pesquisa, acima delineado, pode ser visto como um caso especial e central do que Chomsky denominou o Problema de Platão: como é possivel adquirir conhecimentos altamente abstratos sem instrução ou informação? $\mathrm{O}$ Problema de Platão é reformulado da seguinte forma: Como é possível adquirir uma língua?

Os estudos têm mostrado que a competência linguística que a criança atinge é altamente complexa. E, embora a aquisição encontre pistas seguras no ambiente para fixar a gramática de sua língua materna, o conhecimento final adquirido não está restrito ao que o dado pode informar.

As crianças aprendendo português ou qualquer outra língua sabem, por exemplo, antes da exposição a uma experiência linguística, que as regras são dependentes de estruturas e não lineares. Os constituintes que compõe as sentenças têm uma estrutura hierárquica. Os mecanismos operam automaticamente sem pensamento consciente. Considere-se ainda que as crianças atingem um complexo conhecimento linguístico em um tempo curto, sem esforço ou dificuldades, e sem instrução explícita. Como isto seria possível? Uma resposta seria que recebem direcionamento determinístico do ambiente linguístico. Afinal de contas, se tiver nascido no Brasil, a criança aprenderá uma variedade do português e assim por diante.

No entanto, os longos anos de pesquisa sobre o tema têm revelado que os dados linguísticos primários, disponíveis à criança, não são suficientes para guiá-la na tarefa de adquirir a gramática núcleo da língua materna. Entre os problemas com os dados podemos destacar dois: (i) o conjunto de sentenças ao qual as crianças estão expostas é finito, mas o conhecimento que ela alcança lhe permite construir e entender um número infinito de sentenças; (ii) a criança não recebe instrução sistemática por parte dos pais, professores, ou das pessoas com as quais convive, ou seja, não têm aulas de gramática.

E vejam que estamos nos referindo apenas ao conhecimento gramatical, no sentido dos aspectos lexicais e morfossintáticos. Na verdade, o conhecimento linguístico da criança envolve outros aspectos, como os fonético/fonológicos, semânticos, todos intimamente relacionados.

A resposta que se dá ao problema lógico da aquisição da linguagem envolve, portanto, a hipótese de que parte deste conhecimento é inato, compõe o dote biológico, é parte da 
estrutura da FL, e forma o equipamento mental com o qual a criança enfrenta o mundo da experiência.

Dado um conjunto de evidências desta natureza, o linguista se dirige para a etapa seguinte: descrever a Língua-I que determina estes fatos.

A próxima etapa é explicar por que os fatos são como são. A adequação explicativa leva a uma investigação da FL.

\begin{abstract}
Universal grammar attempts to formulate the principles that enter into the operation of the language faculty after it has been presented with data of experience; universal grammar is an account of the initial state of the faculty of language, before any experience $[\ldots]$ To the extent that we can construct a theory of universal grammar, we have a solution to Plato's problem in this domain
\end{abstract}

(Chomsky, 1988, p. 62)

A criança, com a FL como parte de seu componente genético, é exposta a um ambiente social no qual uma língua particular é falada. Fazendo uso dos dados do ambiente de uma forma determinada por sua estrutura interna, a criança constrói, a partir de etapas de desenvolvimento, um sistema linguístico, uma Língua-I, uma variedade do português, por exemplo, à qual ela foi exposta. Dados muito limitados são suficientes para a FL proporcionar uma língua complexa e tem as propriedades essenciais das línguas faladas, embora com diferentes meios.

A pesquisa do linguísta é, portanto, um processo que começa à direita do diagrama, a partir das expressões estruturadas ou julgamento dos falantes, ou outras evidências, que sugerem, ao menos, uma abordagem parcial da forma e significado das expressões, e caminha para a investigação da FL.

No que se segue, elaboramos outras três seções para ilustrar o que foi acima apresentado a respeito da Teoria dos Princípios e Parâmetros. A seção 2 refere-se ao Parâmetro do Sujeito Nulo. A seção 3 gira em torno das diferentes estratégias para realização do objeto direto, trata-se do Parâmetro do Objeto Nulo. Ambos foram muitos estudados nos anos recentes, e representam importantes mudanças que estão em fase de implementação no PB, em oposição ao português europeu e o português histórico.

A justificativa para a apresentação desses fenômenos é que ambos ilustram de forma clara o distanciamento entre a gramática adquirida na fase da aquisição da linguagem e a gramática aprendida na escola, com o estatuto de variante de prestígio.

O objetivo é destacar os aspectos que nos levam a refletir sobre o papel da escola, seja no resgate das formas de prestígio, seja na consolidação das formas inovadoras. 
Finalmente, na seção 4, nosso objetivo é discutir aspectos da aquisição da linguagem, com foco no aprendizado do PB pelo falante letrado. Para tanto, nossa reflexão se apoia em Kato (2005) e Kato, Cyrino, Corrêa (2009).

\subsection{Parâmetro do Sujeito Nulo}

As línguas se diferenciam com respeito à possibilidade ou não de realizarem fonologicamente o sujeito pronominal de referência definida ou indeterminada. A esta diferença, foi atribuído um estatuto paramétrico conhecido como Parâmetro do Sujeito Nulo (pro-drop), o qual divide as línguas em dois diferentes grupos. Sendo assim, no contexto de diferentes línguas, o português europeu, o espanhol, o italiano e o latim, por exemplo, seriam línguas de sujeito nulo; enquanto o inglês, o alemão e o francês não o seriam. Vejamos uma pequena exemplificação do contraste entre os dois tipos de línguas, com base em uma simples sentença.

(5) a. Falo inglês (PE)

b. Hablo inglés (ESP)

c. * Speak English (ING)

d. * Parle anglais ( FR)

Entretanto, os fatos do PB criam um problema para a tipologia linguística proposta no Parâmetro pro-drop.

Em trabalhos mais recentes, a forma que foi encontrada para caracterizar o PB é a de que se trata de uma língua de sujeito nulo parcial, uma vez que, embora realize o sujeito referencial, em contextos nos quais línguas de sujeito nulo não o realizam, apresenta a possibilidade do chamado sujeito nulo expletivo, com verbos que expressam fenômenos da natureza, sentenças impessoais com verbo haver, sentenças com verbos como parecer, custar, etc.(cf. Duarte, 2007; Kato, 2009). Em (6) apresentamos um dado de português culto falado no Brasil ${ }^{1}$, como exposto em Berlinck, Duarte \& Oliveira (2009), o qual evidencia, de forma clara, a tendência para o preenchimento dos sujeitos pronominais.

\footnotetext{
${ }^{1}$ Esse corpus refere-se ao banco de dados do projeto Nurc (Norma Urbana Culta) formado por três diferentes tipos de inquéritos - D2 (diálogo entre dois informantes), DID (diálogo entre documentador e informante), EF (elocução formal) - e pesquisados nas seguintes capitais: Recife (REC), Salvador (SSA), Rio de Janeiro (RJ), São Paulo (SP) e Porto Alegre (POA).
} 
(6) Normalmente, quando a gente pede para [uma criança $]_{i}$ de por volta de quatro a cinco anos desenhar uma mesa, ela $a_{i}$ põe o tampo que ela ${ }_{i}$ sabe que existe; ela $a_{i}$ põe as pernas para todos os lados. Por quê? Ora, se ela $a_{i}$ olhar de um determinado lado, ela $\mathrm{i}_{\mathrm{i}}$ ê duas pernas; se ela $a_{i}$ andar meio metro, ela $a_{i}$ ê outras duas pernas. Então, ela $a_{i}$ põe pernas para todos os lados, por quê? Porque ela $\mathrm{i}_{\mathrm{i}}$ sabe que a mesa tem um tampo, que é onde ela $a_{i}$ põe as coisas e que a mesa está apoiada em cima das pernas... Agora isso aqui ela $a_{i}$ jamais vai poder ver: essa imagem da mesa. Então isso aqui é o que ela $\mathrm{s}_{\mathrm{i}} \mathrm{sabe}$ Ela $a_{i}$ está desenhando o que ela $a_{i}$ tem na cabeça e não o que ela $a_{i}$ está vendo. (EF SP)

Como observado pelas autoras, os resultados para a $3^{\mathrm{a}}$ pessoa, acompanham aqueles encontrados para a $1^{\mathrm{a}}$ e $2^{\mathrm{a}}$ pessoas. Mais especificamente, a $3^{\mathrm{a}}$ pessoa do singular apresenta $78 \%$ de preenchimento (256 dados em 329) e a $3^{\mathrm{a}}$ do plural, $71 \%$ (98 dados em 138). Se o sujeito tem o referente [+humano], o índice de preenchimento alcança um total de $84 \%$.

Além disso, como Duarte $(2005 ; 2007)$ tem mostrado, em maiores detalhes, há mudanças importantes ocorrendo no contexto das sentenças com verbos impessoais. Trata-se do uso arbitrário dos pronomes você/vocês, ocupando a posição de sujeito estrutural, acompanhado da substituição do verbo haver, pelo verbo ter. Vejamos os exemplos abaixo, similares aos discutidos pela autora ${ }^{2}$ :

(7) a. ___ Há um mercadinho na esquina que vende verduras

b. Tem um mercadinho na esquina que vende verduras

c. Você tem um mercadinho na esquina que vende verduras

Observa-se que essa diminuição no uso do sujeito nulo referencial no PB é encontrada não somente na oralidade, como na escrita, sejam de cartas (cf. Paredes Silva, 1998), sejam de peças de teatro popular (cf. Duarte, 1993). Tal fenômeno tem sido relacionado à diminuição nos paradigmas das desinências verbais, que são iguais para a segunda e terceira pessoas do singular e, algumas vezes, para a primeira do plural, no aumento da forma "a gente" em substituição do "nós".

Com relação a essa mudança no paradigma flexional verbal, observa-se um conflito entre o sistema ainda reproduzido pela escola e o que está efetivamente em uso pelo falante. No ambiente acadêmico, o aluno é "apresentado" a diferentes desinências número-pessoais para cada uma das pessoas dos verbos no modo indicativo (conf. tabela (1) extraída Freire, 2005). Tais desinências não são reproduzidas pelo falante no seu cotidiano e acabam restritas ao espaço escolar.

\footnotetext{
${ }^{2}$ Há várias propostas na literatura, tentando dar conta das restrições apresentadas para o uso de sujeito nulo no $\mathrm{PB}$, mas não trataremos desse assunto neste capítulo.
} 
Tabela 1 - Paradigma flexional do português segundo a tradição escolar

\begin{tabular}{|llllll||}
\hline \multicolumn{2}{|c}{ PRESENTE } & \multicolumn{2}{c|}{ PRETÉRITO IMPERFEITO } & \multicolumn{2}{c|}{ PRETÉRITO PERFEITO } \\
\hline \hline Eu & Canto & Eu & cantava & Eu & cantei \\
$\mathrm{Tu}$ & Cantas & $\mathrm{Tu}$ & cantavas & $\mathrm{Tu}$ & cantaste \\
Ele & Canta & Ele & cantava & Ele & cantou \\
Nós & cantamos & Nós & cantávamos & Nós & cantamos \\
Vós & cantais & Vós & cantáveis & Vós & cantastes \\
Eles & cantam & Eles & cantavam & Eles & cantaram \\
\hline \hline
\end{tabular}

(Freire, 2000, p. 7)

Essas desinências número-pessoais avalizariam ao português a categoria de língua de sujeito nulo, já que as desinências das formas verbais diferentes para cada pessoa gramatical tornariam a evidência do pronome um aspecto redundante, como é o caso do PE, espanhol e italiano. No entanto, como dito acima, pelo que os trabalhos linguísticos têm encontrado, é outra a situação pronominal do PB (conf. Freire, 2000). Devido à competição entre as formas prototípicas de segunda pessoa do singular e plural (tu/vós) e, os pronomes de $2^{\mathrm{a}}$ pessoa você/vocês, o que temos hoje é uma nova realidade no sistema flexional do $\mathrm{PB}$, como vemos na tabela (2), extraída de Freire (2005).

Tabela 2 - Redução do paradigma flexional do PB

\begin{tabular}{|c|c|c|c|c|c|}
\hline \multicolumn{2}{|c|}{ PRESENTE } & \multicolumn{2}{|c|}{$\begin{array}{l}\text { PRETÉRITO } \\
\text { IMPERFEITO }\end{array}$} & \multicolumn{2}{|c|}{ PRETÉRITO PERFEITO } \\
\hline $\mathrm{Eu}$ & Canto & $\mathrm{Eu}$ & \multirow{5}{*}{ cantava } & $\mathrm{Eu}$ & cantei \\
\hline Você & \multirow{4}{*}{ Canta } & Você & & Você & \multirow{4}{*}{ cantou } \\
\hline $\mathrm{Tu}$ & & $\mathrm{Tu}$ & & $\mathrm{Tu}$ & \\
\hline Ele & & Ele & & Ele & \\
\hline A gente & & A gente & & A gente & \\
\hline Vocês & \multirow{2}{*}{ Cantam } & Vocês & \multirow{2}{*}{ cantavam } & Vocês & \multirow{2}{*}{ cantaram } \\
\hline Eles & & Eles & & Eles & \\
\hline
\end{tabular}

(Freire, 2005, p. 12) 
Consequentemente, temos um aumento da representação fonética do sujeito pronominal. Se uma única forma verbal contempla diferentes pessoas gramaticais, a ausência do pronome subjetivo causaria ambiguidade. $\mathrm{O}$ enfraquecimento do sistema flexional no PB (Duarte, 1993) pode ser considerado como a principal causa que leva a perda do Princípio Evite Pronome (Duarte, 1995). O gráfico abaixo extraído de Duarte (1993) reflete o percurso dessa perda com base em peças de teatro dos séculos XIX e XX.

Gráfico 1 - Ocorrência total de sujeitos nulos

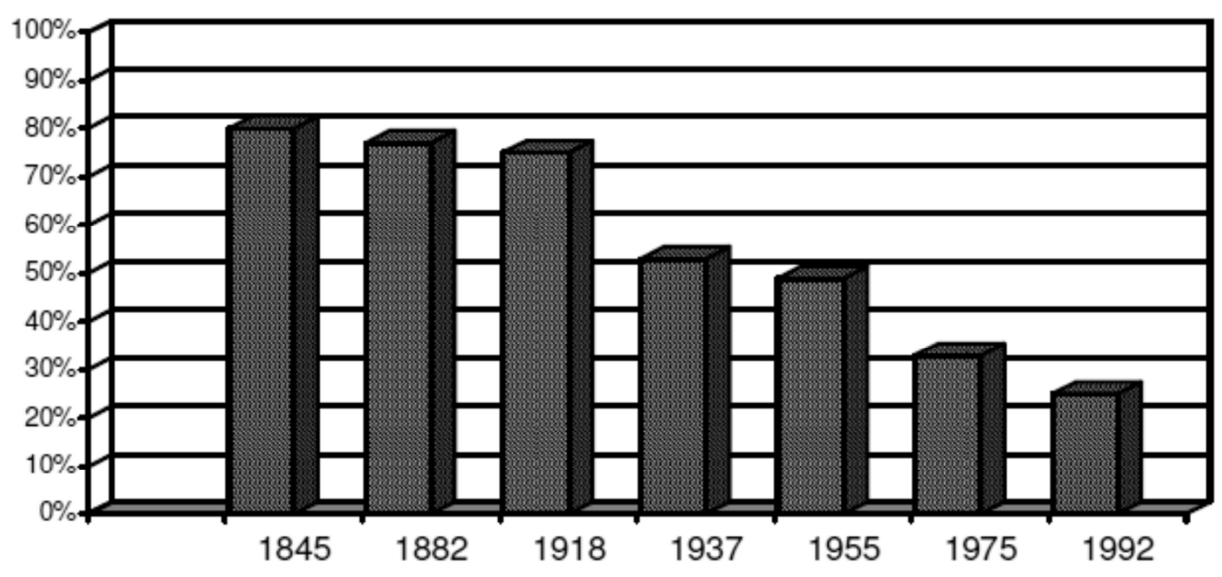

(Duarte, 1993, p. 112)

Portanto, em relação ao sistema pronominal do falante brasileiro, temos que: (i) o uso do sujeito pronominal em contextos em que a flexão verbal é suficientemente rica para recuperar os seus traços gramaticais de número e pessoa (eu estudo inglês; José $e_{i}$ disse que ele estuda inglês); (ii) o uso de você, ao invés de $t u$ e a preferência pela forma a gente, em detrimento de nós, (iii) a baixa frequência dos clíticos acusativos e dativos, para referir à $3^{\text {a }}$ pessoa, (iv) o rearranjo do sistema dos pronomes possessivos; (v) a próclise generalizada ao verbo principal. ${ }^{3}$

Com isto, surgem várias perguntas: (i) como os falantes do PB adquirem as formas inovadoras? (ii) como caracterizar a Língua-I da criança que entra na escola? (iii) qual o papel da escola no resgate das formas de prestígio?

\subsubsection{A aquisição dos pronomes sujeito}

\footnotetext{
${ }^{3}$ Exemplos extraídos de Torres Morais e Ribeiro (2005)
} 
Várias pesquisas mostram que há uma fase na aquisição durante a qual as crianças omitem, opcionalmente, o sujeito sentencial mesmo que na sua língua essa omissão não seja permitida. ${ }^{4}$ Simões (1997), por exemplo, observou durante um ano o desenvolvimento linguístico de uma criança a partir de 2 anos e 4 meses adquirindo o PB no que concerne à realização dos pronomes sujeito.

Em seus resultados, o percentual de uso de sujeito nulo da criança é mais baixo que o percentual de uso de crianças adquirindo línguas de sujeito nulo típicas, como o italiano e o PE. O que eles revelam é que os usos de sujeito realizado na fala da criança brasileira é comparável aos de aquisição de uma língua que não permite sujeito nulo.

\begin{abstract}
Os dados mostram que a gramática intermediária em questão conta com um tipo de sujeito nulo mais restrito em termos percentuais do que o sujeito nulo de línguas que contam com a opção de codificar seus sujeitos através de um pronominal nulo identificado localmente. Essa propriedade diferencia a gramática em estudo daquela do português europeu adulto e do português europeu infantil nessa faixa etária
\end{abstract}

(Simões, 1997, p. 170)

Um resultado interessante da pesquisa de Simões é que a criança apresenta um percentual muito mais elevado de nulos de $3^{\mathrm{a}}$ pessoa (em torno de $60 \%$ ) do que $1^{\mathrm{a}}$ e $2^{\mathrm{a}}$ (em torno de 35\%). Com base nessa comparação, Simões chega à conclusão de que apesar das diferenças quantitativas observadas, esse contraste nas pessoas do discurso pode ser indicativa de que a criança tenha restrições semelhantes às do adulto no uso de nulos.

Além disso, para estabelecer uma comparação com a aquisição de uma língua que não permite sujeito nulo, como o inglês, Simões (1999) confrontou os dados de duas crianças: uma brasileira, André, e uma americana, $\mathrm{A}^{5}$; ambas com a mesma faixa etária, em torno dos 2 aos 3 anos.

No gráfico (2) abaixo se pode notar que há uma tendência de queda percentual correspondente à crescente restrição do uso de nulos nos dados inglês. De fato, no Período 1, Adam apresenta um percentual de quase $60 \%$ de nulo e, no período 2, esse percentual não chega a 30\%. Ao contrário, nos dados da criança brasileira, tal restrição não se verifica e o que se observa é uma estabilidade percentual nesses usos, em torno de $40 \%$, em ambos os períodos.

\footnotetext{
${ }^{4}$ Confira Magalhães (2006) para bibliografia relevante a respeito desse fenômeno da gramática infantil

${ }^{5}$ Confira Simões (1999) para bibliografia relevante sobre os dados da criança americana.
} 
Gráfico 2 - Sujeito nulo na aquisição do inglês e do PB

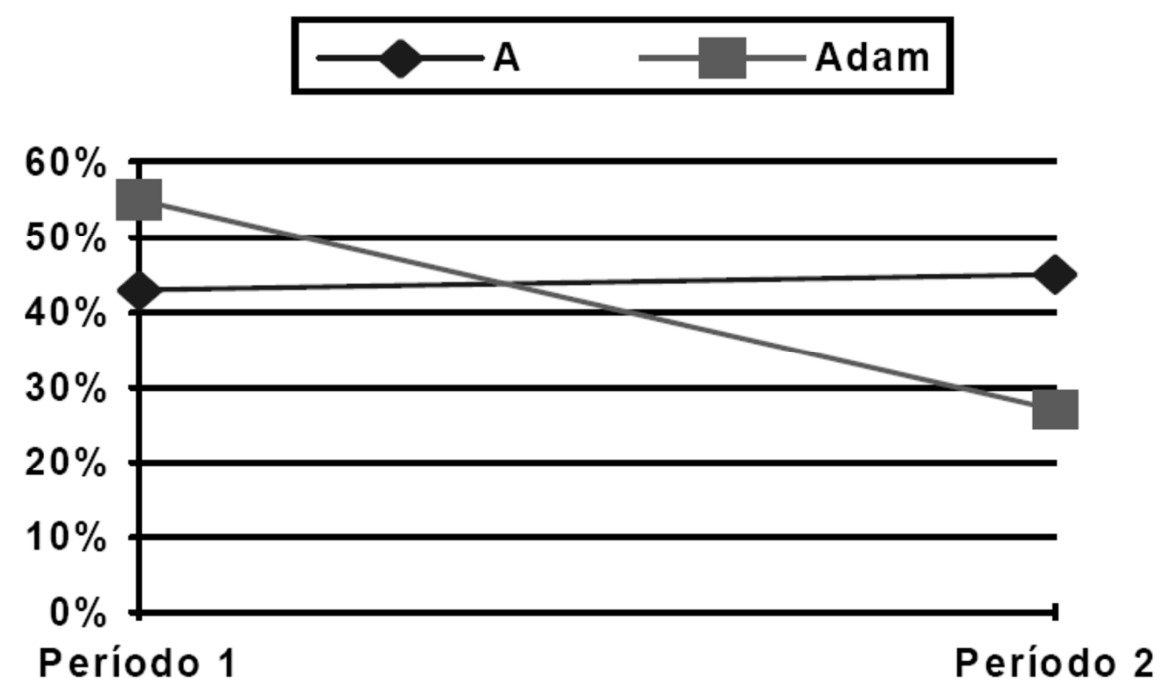

(Simões, 1999, p. 109)

Após esses resultados, a pesquisadora conclui que

ainda que não tenhamos observado uma crescente restrição no uso de nulos nessa faixa etária, os dados do PB alinham-se melhor a dados de aquisição de línguas que não permitem sujeito nulo em sua gramática estável do que àqueles de línguas de sujeito nulo típicas.

(Simões, 1999, p. 109)

Lopes (2003) analisou uma criança de 1 ano e 9 meses até os 3 anos e também observou a preferência por pronomes realizados na posição de sujeito na aquisição do PB. A pesquisadora atentou, ainda, que há a passagem por dois estágios de desenvolvimento na produção de pronomes realizados lexicalmente: um que vai de 1 ano e 9 meses a 2 anos e 8 meses, durante o qual a criança mostra um comportamento muito diferente do esperado para a gramática adulta, e outro quando já está com 3 anos em que a produção de sujeitos já se aproxima daquela do adulto: no primeiro estágio, $47.2 \%$ de pronomes e $44.1 \%$ de sujeitos nulos; no segundo estágio, $52.9 \%$ de pronomes e $32.9 \%$ de sujeitos nulos.

Já o trabalho de Magalhães (2006) apresenta o comportamento linguístico de quatro crianças, duas brasileiras e duas portuguesas com idade entre 1 e 3 anos. Em ambas as crianças brasileiras, observou-se um estágio durante o qual o uso de sujeitos nulos e de pronomes fica distante da gramática-alvo e outro em que o uso de pronomes passa a ter preferência sobre o uso de nulos referenciais, apresentando percentuais mais próximos daqueles da gramática-alvo, ou seja, da gramática do adulto. Para a autora, 
Diferentemente do inglês, o percentual de sujeitos nulos encontrado no PB demonstra que as crianças ainda contam com algum tipo de sujeito nulo. É claro que, como já afirmado por Simões (1997; 2000), os percentuais de sujeito nulos apresentados pelo PB são baixos quando comparados com aqueles apresentados por línguas tipicamente de sujeito nulo como o Italiano, Espanhol ou o Português Europeu. Mas ainda são altos quando comparados aos índices apresentados por línguas que não mais licenciam o sujeito nulo, como por exemplo, o inglês.

(Magalhães, 2006, p. 67)

Para Kato (apud Magalhães, 2006, p. 67) este percentual alto de sujeitos nulos talvez tenha a ver com a alta escolarização dos pais. Ou seja, o sujeito nulo pode advir deste input recebido pela criança no ambiente familiar.

Se os trabalhos sobre aquisição do sujeito pronominal já mostram um aumento na produção dos sujeitos pronominais, poderíamos inferir que na fase pré-escolar a criança brasileira já teria fixado um valor paramétrico em sua Língua-I, ou seja, a de que o PB é uma língua que perdeu o Parâmetro Evite Pronome (conf. Duarte 1995). A criança brasileira, portanto, já adquiriu a mesma propriedade gramatical da língua-alvo, uma vez que os trabalhos tem mostrado que a perda desse parâmetro já está ratificada na fala culta do PB.

Por outro lado, na língua escrita culta há uma valorização do sujeito nulo como forma de prestígio, logo, até que ponto a escola resgataria essa gramática de prestígio?

A resposta não seria tão simples. Averbug (2003) em corpus centrado na produção escrita realizada em sala de aula, por cem alunos de Ensino Fundamental (Classe de Alfabetização, $4^{\mathrm{a}}$ e $8^{\mathrm{a}}$ série), Ensino Médio ( $3^{\circ}$ ano) e Superior (turmas de Português Instrumental) encontrou $47 \%$ de pronomes nulos, $28 \%$ de pronomes plenos, $19 \%$ de SNs anafóricos e apenas $6 \%$ de SNs novos.

Constatou-se, então, uma frequência bem mais acentuada de pronome nulo do que em trabalho de Duarte (1995), que registra um total de 29\%. "Parte deste resultado pode estar fortemente condicionado ao fato de a escrita dos textos ser realizada em ambiente escolar." (Averbug, 2003)

Pode-se observar, ainda, que essa variante considerada padrão para a representação de sujeito pronominal cresce conforme aumenta o tempo de permanência do aluno na escola.

De certa forma, se mantém até a $8^{\mathrm{a}}$ série com frequências próximas (31\% e $39 \%$ ), passa a quase metade das ocorrências no Ensino Médio (49\%) e se consolida como estratégia preferencial entre os universitários (65\%). Esses resultados confirmam a formalidade do sujeito nulo, condicionada pelo estilo. 
Kato (1994) critica o ensino unicamente centrado na aprendizagem de variantes mais formais, já ausentes no período de aquisição - o que pode acentuar ainda mais a dissonância entre o "pretendido" pelo professor e a competência e o desempenho dos estudantes.

Diante deste quadro, cabe-nos questionar (i) qual é a atuação da escola para o aumento das formas nulas? (ii) por que o falante produz mais formas nulas em textos escritos mais formais?

Ao final desta seção, o que mostramos foi que o PB está se tornando uma língua que realiza sujeitos pronominais com maior frequência, e em diferentes contextos, fato esse que o diferencia das línguas pro drop. As pesquisas sobre aquisição do PB revelam que as crianças começam a preencher a posição de sujeito em torno dos 3 anos de idade e essa é a forma fixada pelo falante, mesmo por aqueles que passam pelos bancos escolares. O que se constatou nos estudos quantitativos foi que as formas nulas estão mais produtivas na escrita de textos mais elaborados. Para Kato, Cyrino e Corrêa (2009), essa escolha teria relação com com a periferia marcada que cerca a gramática núcleo do indivíduo letrado.

Vale lembrar que Kato (2005) considera duas hipóteses para a aquisição de uma "segunda gramática" por parte do falante letrado:

a) o falante letrado tem duas gramáticas nucleares, como um bilíngue "stricto sensu" tardio...

b) o falante letrado é um bilíngue desigual que têm, em sua Língua-I, uma periferia marcada maior do que a dos não letrados. O termo desigual se refere a esse tipo particular de bilinguismo, que faz alternância de código entre a G1 da gramática nuclear e a G2 na periferia marcada. A G2, na concepção de Kato, não tem a mesma natureza da G1. A G2 é constituída de fragmentos superficiais de uma gramática constituída pela fixação de parâmetros. Um exemplo seria o do parâmetro do sujeito nulo. Ao invés de ter todas as propriedades de uma língua de sujeito nulo, como o português europeu, a G2 seleciona apenas a omissão do sujeito, e em contextos bastante restritos. Portanto, segundo Kato, o que ocorre efetivamente, é que a "G2" é constituída, não por seleção paramétrica, mas por "regras estilísticas", adquiridas no "input" escolar e que refletem escolhas arbitrárias de gramáticas passadas ou empréstimos da gramática portuguesa.

Em suma, Kato reconhece diferenças entre a aquisição de L2 "stricto sensu" e aquisição de L2 pela aprendizagem da escrita. 


\subsection{Objeto direto nulo no PB}

No que diz respeito ao objeto direto anafórico de $3^{\mathrm{a}}$ pessoa, observa-se, que, na variante culta do PB, há uma realização bastante característica: trata-se do objeto direto nulo, o qual coexiste com três outras estratégias: o pronome pleno, o clítico, e o sintagma nominal (SN). Há um percentual diferente na realização de cada uma das estratégias. Com base nos dados do português culto falado no Brasil, Cyrino, Nunes e Pagotto (2009) apresentam uma detalhada análise da produtividade de cada uma das formas, em diferentes contextos verbais, finitude do verbo, e tipo semântico do objeto. Em (8) apresentamos exemplos que contemplam três das estratégias acima mencionadas: a forma pronominal plena, o clítico e a forma nula:

(8) a. seria muito mais importante vocês gravarem eles . (D2 REC 05)

b. não seria conveniente mudá-lo de período escolar ? (D2 SP 360)

c. pra mim realmente é um sacrifício... às vezes vejo pastel ... me dá vontade de comer $[\phi]$, mas eu procuro evitar. (DID RJ 328)

O objeto nulo tem sido estudado de forma sistemática no PB, tanto sincronicamente, quanto na diacronia, e pelos grupos que tratam da aquisição da linguagem. Há, de fato, uma enorme literatura sobre o assunto. Os linguistas se dividem quanto às hipóteses que assumem a respeito da natureza da categoria vazia ${ }^{6}$. Alguns afirmam que a alta frequência dos objetos nulos na produção adulta pode ser considerada uma estratégia de esquiva para o uso dos pronomes nominativos ele, ela, eles, elas como objetos diretos. Como se sabe, esta estratégia é ainda altamente estigmatizada nos manuais escolares e ensino normativo. Quanto aos clíticos acusativos de $3^{\mathrm{a}}$ pessoa, sabemos que não fazem parte do nosso vernáculo e o seu emprego está relacionado ao aprendizado escolar, ao grau de instrução do falante, à escrita e ao estilo formal segundo (conf. Duarte, 1986).

Isto se deve ao fato de que a realização clítica do objeto direto de $3^{\mathrm{a}}$ pessoa não mais constitui dado sólido o suficiente para estar disponível durante o processo de aquisição da

\footnotetext{
${ }^{6}$ Cyrino (1994), em estudo que leva em conta dados diacrônicos do PB, afirma que, da mesma forma que o português europeu clássico, o PB pode apresentar objeto nulo quando o antecedente é um NP não-específico ou não-referencial. Além disso, quando o antecedente é [-animado], o PB apresenta objeto nulo, diferentemente do português europeu, que restringe mais a ocorrência dessa categoria vazia, sendo um subcaso de elipse.
} 
linguagem, pela criança, como apontam os dados levantados em Corrêa (1991), Averbug (1998, 2000), Magalhães (2006) e Dutra (2003).

Magalhães (2006), em particular, estudando a realização do objeto direto nas crianças brasileiras e portuguesas, não encontrou clíticos acusativos de terceira pessoa na sua amostra de dados do PB. Verificou, porém, que as crianças portuguesas adquirem-nos precocemente. Nos dados de uma das crianças portuguesas foram identificadas 54 ocorrências, ou seja, 34\% de todas as categorias objetos da amostra. Ressalta-se, no entanto, que o maior percentual de clíticos concentra-se nas últimas sessões da criança, a partir dos 2 anos e 8 meses. O que indica que a aquisição desta categoria é mais tardia.

Além disso, a pesquisadora identificou que, nas crianças brasileiras, não se vê uma preferência pelos objetos nulos, como se esperaria pelos resultados que têm sido apontados para a fala do adulto. O objeto nulo tem um maior percentual de uso até os 2 anos e depois entra em competição com o objeto preenchido.

Apesar dessa competição entre objetos nulos e preenchidos, ainda assim as crianças brasileiras usam em média mais objetos nulos que as crianças portuguesas. Ou seja, as crianças portuguesas usam sujeitos nulos, mas preferem usar objetos preenchidos. As crianças brasileiras usam mais sujeitos preenchidos, mas preferem usar mais objetos nulos.

Em gráfico que compara a média de objetos nulos nas duas crianças brasileiras e nas duas portuguesas, observamos o seguinte ${ }^{7}$ :

Gráfico 3 - Objetos nulos na aquisição do PB e do PE

\footnotetext{
${ }^{7} \mathrm{O}$ resultado do gráfico 3 corresponde a uma média entre as duas crianças brasileiras estudadas na pesquisa e das duas crianças portuguesas. Foi, portanto, reelaborado por mim a partir de dados colhidos na dissertação citada (Magalhães, 2006)
} 


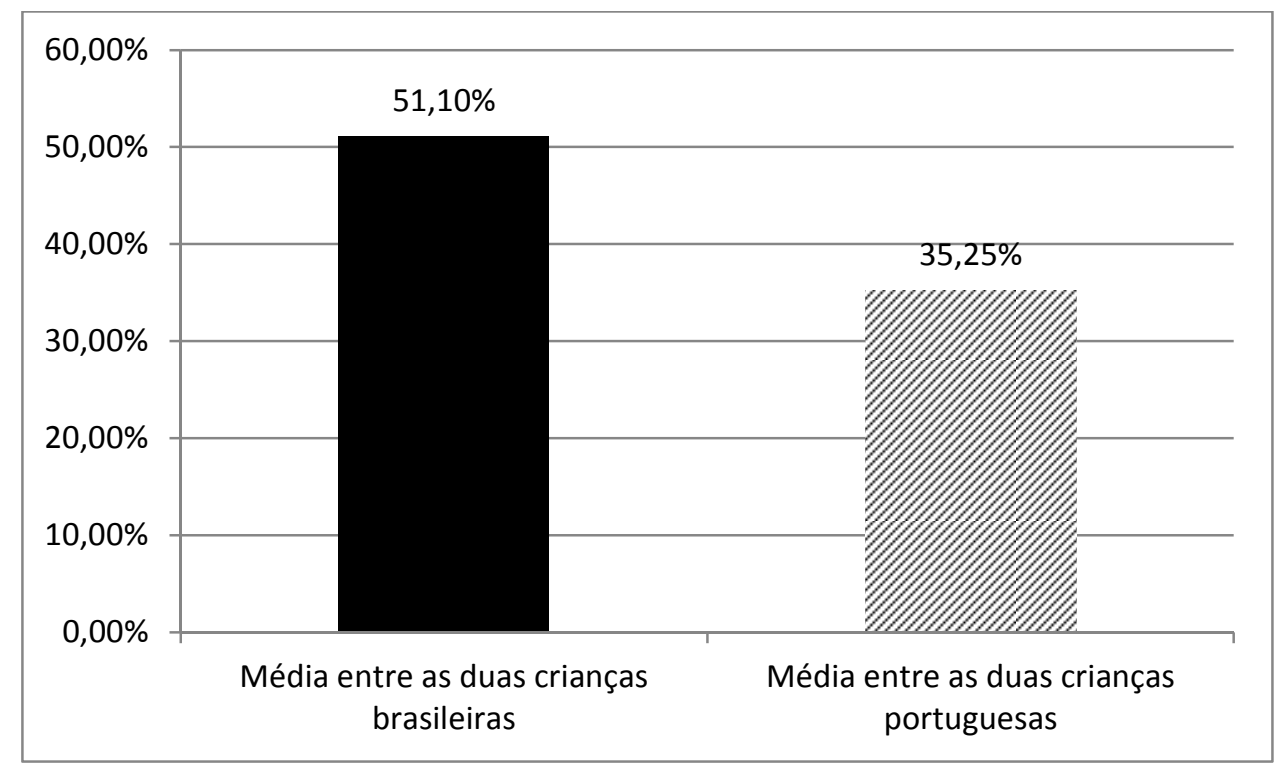

Ainda com relação ao objeto pronominal, como dito, não foram encontrados clíticos acusativos de terceira pessoa, confirmando-se, portanto, as direções das pesquisas sobre o PB de que tais elementos não mais fazem parte da gramática do adulto. Quanto aos demais clíticos acusativos, foi encontrado somente um caso de primeira pessoa nos dados de uma das crianças.

Se a criança não fixa o clítico acusativo durante o processo de aquisição, caberia à escola municiar o indivíduo com habilidade de usá-lo de modo proficiente (Duarte, 1989, p. 29). No entanto, Corrêa (1991) conclui que esse não seja um aprendizado simples, pois nos dados levantados em textos e narrações escolares, aparecem casos de hipercorreção, de objeto duplo e problemas de concordância verbal.

A autora afirma que o contexto favorito do uso dos clíticos é a língua escrita culta e sua aprendizagem coincide com a aquisição da concordância. Assim, o uso do clítico identifica uma variante culta do PB, diferentemente do que ocorre no PE e em outras línguas românicas. (Corrêa, 1991, p.45)

Por sua vez, Averbug (2000), em já citada investigação em produções escritas realizadas por alunos de Ensino Fundamental, Ensino Médio e Superior, constatou 35\% de uso do objeto nulo e $23 \%$ de clíticos.

No gráfico, é possível acompanhar a evolução no aprendizado do aluno, relativa ao emprego do objeto direto anafórico.

Gráfico 4 - A realização do objeto direto anafórico de acordo com o grau de escolaridade do aluno. 


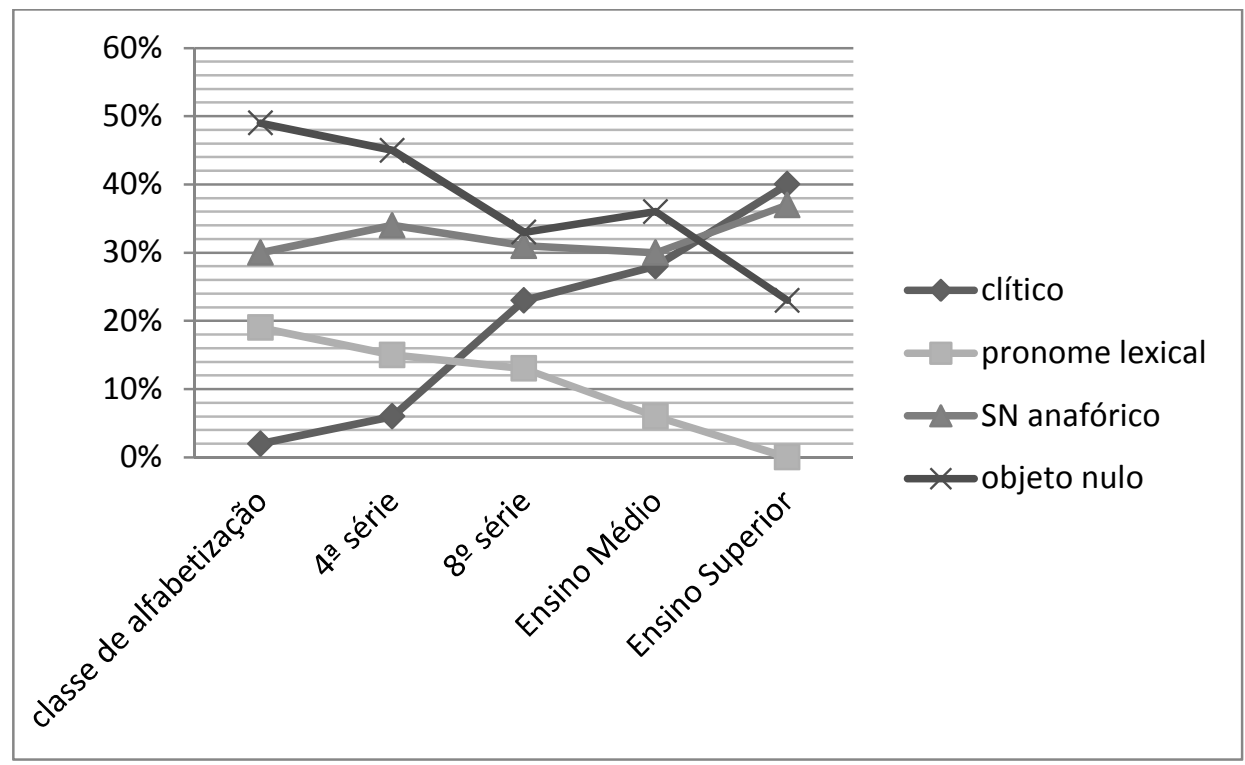

(Averbug, 2000, p.112)

A frequência do clítico cresce paulatinamente de $2 \%$, na classe de alfabetização, para $40 \%$ no Ensino Superior, e o pronome lexical cai de 19\% para nenhuma ocorrência. Já o emprego de SNs lexicais plenos parece não ser afetado, mantendo-se entre 30 e 37\%, aparecendo como uma estratégia neutra. $\mathrm{O}$ objeto nulo é a variante preferida até a $3^{\mathrm{a}}$ série do Ensino Médio, principalmente pelo $1^{\circ}$ segmento do Ensino Fundamental (próximo aos 50\%); porém, no último estágio de escolaridade, perde para o clítico acusativo (40\%) e o SN anafórico $(37 \%)$.

Os resultados revelam que, até certo ponto, a escola recupera certas formas ausentes da língua oral, embora essa "recuperação" seja apenas parcial. Se a escrita dos alunos consegue reproduzir o padrão, implementa também variantes da língua oral, particularmente em contextos já consagrados na fala.

(Averbug, 2003, p. 108)

Para a autora, o elevado número de ocorrências de clítico acusativo e o aumento do pronome nulo na posição de sujeito são resultado da exposição dos alunos a textos escritos, e não se relacionam à ação direta do professor.

A inegável implementação do objeto nulo na escrita e o emprego dos SNs anafóricos como formas legítimas de representação de sujeito e de objeto direto não podem ser ignorados para uma descrição gramatical mais completa do português brasileiro.

(Averbug, 2003, p. 108) 
Outra pesquisa, realizada por Dutra (2003), em corpus composto por redações escolares de estudantes da $8^{\text {a }}$ série do Ensino Fundamental (atual $9^{\circ}$ ano), da $3^{\text {a }}$ série do Ensino Médio e do $4^{\circ}$ semestre da Licenciatura em Letras confirmou as conclusões de Duarte (1986) e Corrêa (1991), a respeito de um fenômeno: os referentes com o traço semântico [+animado] favorecem a ocorrência do clítico acusativo e os referentes com traço [-animado] favorecem a substituição do clítico por outra variante de objeto anafórico, preferencialmente os sintagmas nominais e a forma nula.

Diferentemente dos dados apontados por Averbug e Corrêa, Dutra aponta que, em relação à escolaridade, os informantes da oitava série do Ensino Fundamental foram os que mais usaram o clítico acusativo e os do Ensino Superior são os que menos se servem dessa variante. "A observação desse resultado foi surpreendente, uma vez que acreditávamos, como Corrêa (1991), que o número de ocorrências de clítico na redação escolar aumentasse com a progressão da escolaridade." (Dutra, 2003, p. 90)

Constatou-se que o uso do clítico, então, decresce no Ensino Médio e decresce mais um pouco no Ensino Superior. Tal fato, como se disse, contraria a expectativa de que, quanto maior o grau da escolaridade, maior a preferência por clíticos acusativos para representar o objeto anafórico, já que a escola municia o indivíduo com a habilidade de usar o clítico e esse fator, associado à idade, é relevante para a realização dessa variante.

Para compreender as diferenças assinaladas com relação a essas pesquisas, Dutra levanta a hipótese de que as condições de produção dos textos tenham interferido na escolha da variante de objeto pressuposto.

Como os textos foram escritos em situação normal de aula e a pedido do professor de português, é possível que o uso mais frequente do clítico na oitava série esteja associado à também possivelmente frequente insistência dos professores do Ensino Fundamental para que os escolares não repitam palavras e expressões em seus textos.

(Dutra, 2003, p. 100)

Para a pesquisadora, conforme o indivíduo progride em termos de escolaridade, entretanto, é possível que se vá libertando da pressão exercida pelo professor do Ensino Fundamental. Ao chegar à metade do Curso de Letras acredita-se que tenham construído sua autonomia redacional e, portanto, escolham os recursos que melhor se ajustem a seu estilo, o que pode produzir a queda no uso de clíticos. 
Essa divergência apontada pelos estudos no que se refere ao uso dos clíticos entre usuários de diferentes níveis de escolaridades já não é percebida se o foco do estudo for geográfico. Em uma revisão da literatura sobre os usos do objeto direto de $3^{\text {a }}$ pessoa, Freire (2005) traça um comparativo entre os estudos da fala paulistana, carioca, catarinense e brasiliense realizados respectivamente por diferentes pesquisadores ${ }^{8}$ em que se analisaram qualitativa e quantitativamente as formas de realização do objeto direto de $3^{\mathrm{a}}$ pessoa. Os dados foram compilados na tabela abaixo:

Tabela 3 - Realização do objeto direto de $3^{\text {a }}$ pessoa em quatro diferentes cidades brasileiras.

\begin{tabular}{|l|c|c|c|c|}
\hline & $\begin{array}{c}\text { São Paulo } \\
\text { (Duarte, } \\
\text { 1986) }\end{array}$ & $\begin{array}{c}\text { Rio de Janeiro } \\
\text { (Pará, 1997) }\end{array}$ & $\begin{array}{c}\text { Santa } \\
\text { Catarina } \\
\text { (Luize, } \\
\text { 1997) }\end{array}$ & $\begin{array}{c}\text { Distrito } \\
\text { Federal } \\
\text { (Malvar, 1992) }\end{array}$ \\
\hline Clítico acusativo & $5 \%$ & $0 \%$ & $1 \%$ & $1 \%$ \\
\hline Objeto nulo & $63 \%$ & $63 \%$ & $54 \%$ & $46 \%$ \\
\hline $\begin{array}{l}\text { Realização plena } \\
(\mathrm{SN})\end{array}$ & $17 \%$ & $24 \%$ & $36 \%$ & $28 \%$ \\
\hline $\begin{array}{l}\text { Pronome tônico } \\
(\text { ele) }\end{array}$ & $15 \%$ & $14 \%$ & $9 \%$ & $25 \%$ \\
\hline
\end{tabular}

A tabela aponta regularidade e supremacia no uso da forma nula em oposição às ínfimas ocorrências de clítico acusativo, mais preponderante em São Paulo.

É importante observar que os dados de fala do Rio de Janeiro e de Santa Catarina são de 1997, ou seja, cinco anos posterior ao trabalho sobre a fala do Distrito Federal (1992) e com onze anos de diferença em relação aos dados de São Paulo (1986). Logo, pode-se afirmar que há uma mudança em progresso.

Ao longo desta dissertação iremos focalizar os clíticos dativos de $3^{\text {a }}$ pessoa, especificamente nos textos escritos de estudantes, já que diferentes estudos comprovaram que, enquanto o acusativo praticamente foi eliminado da fala espontânea, o de função dativa

\footnotetext{
${ }^{8}$ Consulte Oliveira (2005) para bibliografia relevante
} 
mostra-se ainda produtivo, porém em referência à segunda pessoa, com o valor de acusativo e dativo. Por essa razão, diz-se que é especialmente a terceira pessoa a mais afetada pelo fenômeno da perda de clíticos.

\subsection{Aquisição do PB pelo falante letrado}

Antes de finalizarmos este capítulo, pensamos ser importante tecer alguns comentários sobre o conhecimento linguístico do letrado, pois se, como visto nas seções anteriores, há formas em competição no PB utilizadas em indivíduos com diferentes níveis de escolaridade, questiona-se como seria a aquisição do falante dessa língua e o aprendizado realizado por meio da escola.

Como discutido na seção 1, na perspectiva da Teoria dos Princípios e Parâmetros, a criança adquire uma língua materna a partir da exposição a dados linguísticos primários e passa por fases intermediárias no período de assimilação da língua-alvo, que vai até em torno dos 7 anos. Na fase inicial, encontra-se a Gramática Universal (GU) como dote biológico, tal qual um aparelho fonador ou visual, antes da exposição ao ambiente linguístico. A GU contém as propriedades capazes de direcionar a criança na aquisição de uma língua ao qual ela está exposta. Ou seja, a criança vem dotada com propriedades inatas, mas deve estar exposta à experiência linguística e, com base nessa interação, vai fixando a gramática-núcleo da sua língua. (Chomsky, 1986).

Como dissemos, a GU é constituída de princípios rígidos, invariáveis entre as línguas, e de parâmetros que codificam as propriedades que variam de uma língua para outra. Os princípios e os parâmetros são inatos, porque ambos são dados pela GU. No entanto, como os parâmetros são propriedades subespecificadas, a tarefa da criança é marcar o valor apropriado do parâmetro, tendo por base os dados positivos da língua-alvo. A GU contém propriedades capazes de direcionar a criança a aquisição de uma língua ao qual ela está exposta, ou seja, a criança vem dotada com propriedades inatas, mas deve estar exposta a experiência linguística e com base nesta interação vai fixando a gramática-núcleo de sua língua.

Dentro deste modelo, a noção de Língua-I refere-se à competência linguística do falante interiorizada em sua mente. No entanto, Kato (1995) e Kato, Cyrino e Corrêa (2009) levantam uma preocupação que resulta do fato de que esse conceito da Língua-I não distingue 
entre o conhecimento linguístico de uma criança iniciando o processo escolar e o de uma pessoa que já passou por todo um processo de letramento.

As autoras se propõem a formular e tentar responder às seguintes questões que são paralelas as de Chomsky (1986), no que diz respeito à Língua-I

a) qual é a forma do conhecimento linguístico de um adulto brasileiro escolarizado? e

b) como esse conhecimento se desenvolveu?

Ou seja, como descrever a Língua-I de um falante que completou os 12 anos de educação básica formal na escola, e que, nesse instante passa a apresentar outra competência linguística? Além disso, como esse conhecimento se desenvolveu?

Para dar uma resposta a essa questão, Kato, Cyrino e Corrêa (2009) estudam a recuperação dos pronomes acusativos de $3^{\text {a }}$ pessoa $(o, a, o s$, as) e comparam resultados históricos com dados do português brasileiro atual e concluem que a escola recupera esses clíticos, porém, não recupera inúmeras outras propriedades gramaticais. Por exemplo, a colocação dos clíticos torna-se proclítica, enquanto no PE há preferência pela ênclise. Em relação à fala, o resgate é de $14 \%$ de clíticos, $65 \%$ de objeto nulo e $7 \%$ de pronome lexical. Os mesmos universitários, quando escrevem, produzem $80 \%$ de clíticos.

Diante deste quadro, as autoras se perguntam se teria havido efetiva recuperação no uso dos clíticos. Para as autoras, esse não seria o caso, os clíticos são usados, mas não como ocorriam em dados históricos, como já comprovado na pesquisa linguística do PB.

Como explicar estes resultados? A resposta encontrada por elas para esta questão é a de que a escola seleciona certos fósseis da linguagem como sendo gramaticais. No entanto, não se trata de fatos gramaticais, mas de escolhas estilísticas que não contemplam o campo da gramática. Quando o aluno escreve, ele escolhe um estilo e, a partir daí, resgata o que ele aprende como língua do passado, pois ele tem a concepção de que necessita usar essas formas em textos mais formais.

Finalmente, a resposta das autoras aos questionamentos sobre a Língua-I poderia ser resumida da seguinte maneira: a Língua-I dos falantes escolarizados consiste em uma gramática adquirida na infância que está refletida em sua maior parte na produção oral, acrescida de uma periferia de regras estilísticas adquiridas por meio da escolaridade que se reflete na sua escrita. Por esta razão, frequentemente o falante muda o código entre formas licenciadas e as formas aprendidas na escola. 
Kato (2005) assume, portanto, que a aquisição da gramática começa a ser formada antes da vida escolar, tanto a nuclear quanto a periférica. Esta última se configura pelo acesso à leitura e pela convivência com adultos que utilizam uma variante mais culta da língua. Por exemplo, meninos e meninas que tiveram grande exposição a conto de fadas de reis e rainhas poderão ter no seu conhecimento periférico sujeitos nulos, tais como "Estarei as suas ordens!" e "Sois a minha rainha!" E aqueles que frequentam celebrações católicas e escutam trechos bíblicos, por exemplo, "Naquele tempo, disse Jesus", podem produzir hipérbato.

No entanto, como veremos no capítulo 4, não encontramos diferenças na produção das crianças de escola pública e da escola particular, no que se refere às estratégias de realização do OI. Tomamos como pressuposto que as crianças provenientes de uma situação socioeconômica mais privilegiada poderiam manifestar uma competência linguística mais efetiva, porém essa suposição não se concretizou e a gramática internalizada pelos alunos da escola pública e particular foram próximas no que se refere à realização do OI de $3^{\text {a }}$ pessoa.

\section{O Objeto indireto no PB}

Neste capítulo iremos nos voltar para uma $3^{\mathrm{a}}$ relação gramatical. Trata-se do objeto indireto $(\mathrm{OI})$. Ao contrário do sujeito e do objeto direto que são funções cuja classificação não gera imprecisão, tanto pelos gramáticos tradicionais como pelos linguistas, a função objeto indireto é mais complexa na sua descrição e identificação. Prova disto é que se propõe em determinadas gramáticas brasileiras uma descrição que se aproxima muito daquela feita para o PE moderno. (Mateus et al., 2003).

Questiona-se, então, por que esta categoria apresenta tais dificuldades particulares na sua definição. A resposta contemplaria alguns itens:

a) Por ser introduzido por preposição torna-se difícil no contexto dos verbos bitransitivos, separar o OI dos demais complementos introduzidos por preposição.

b) O OI é uma função que se caracteriza por uma realização morfológica em termos pronominais. Em particular, na $3^{\mathrm{a}}$ pessoa é realizado pelos pronomes lhe/lhes.

Diante dessa complexidade, pretende-se neste capítulo, o qual se divide em quatro seções, realizar um estudo acerca das propriedades do OI especificamente no contexto dos verbos bitransitivos. 
Para isso, na primeira seção, resgatamos as acepções que os verbos bitransitivos recebem. Salientamos que, nesta revisão, selecionamos apenas os contextos dos verbos bitransitivos em que o verbo apresenta dois complementos: objeto direto e objeto indireto, entendendo, então, a bitransitividade como verbos que selecionam dois complementos. Ademais, partimos dos conceitos de Mateus et al. (2003), cujo estudo, apesar de receber o rótulo de "gramática", se distancia dos gramáticos, por não conter caráter normativo e ser baseado no PE moderno. Assim, confrontamos a descrição proposta pela linguista com as de Câmara Junior (2002), Bechara (2002) e Rocha Lima (1998).

O critério desta escolha partiu de uma reflexão, a de que a descrição do OI nesses três autores tem características semelhantes à descrição feita para o PE: o OI seria o complemento precedido pela preposição $a$ e pronominalizado por lhe.

Diante desse quadro, questionamo-nos se as descrições dos autores brasileiros dariam conta do que é o OI no PB culto. Para responder a essa questão analisamos, na segunda seção, os trabalhos dos linguistas que trataram sincronicamente dessa categoria e observaram as variações e mudanças que ocorrem no PB. Entre eles Berlinck (1996), Torres Morais e Berlinck (2006), Moretti (2010) e Armelin (2011).

Na seção 3, desenvolvemos um panorama sobre as pesquisas diacrônicas do OI no PB, que apontam para a queda no uso do clítico dativo de $3^{\mathrm{a}}$ pessoa - lhe/lhes - o qual foi substituído pelas formas antecedidas pelas preposições a/para seguidas do pronome forte e para a diminuição no uso de $a$ nas realizações da forma preposicionada do objeto indireto, havendo a preferência por para.

Finalmente, centramos nossa atenção, na seção 4, em alguns trabalhos que tentam responder a uma pergunta muito importante, relacionada diretamente a essa dissertação, a saber: Até que ponto a escola resgata as formas consideradas cultas pela tradição gramatical na prática linguística dos alunos? Para esta reflexão, comparamos o trabalho de Freire (2011), em que o autor faz uma análise do ensino dos clíticos pelos livros escolares, com os dados encontrados por Santos (2007) sobre a realização do OI em testes escritos por alunos, cursando desde a $5^{a}$ série do ensino fundamental até o $3^{\circ}$ ano do ensino médio (EM). Esperase, desta forma, levantar algumas reflexões sobre: (i) qual a forma de preenchimento do clítico dativo fixado pela criança e pelo letrado culto brasileiro? (ii) qual o desempenho da escola na tentativa de resgatar o clítico de prestígio em seus alunos? 


\subsection{A definição dos verbos bitransitivos de acordo com a Gramática Tradicional ${ }^{9}$}

Cunha e Cintra (1985) apresentam uma posição radical em relação ao OI nos contextos dos verbos bitransitivos, os quais denomina como verbos transitivos diretos e indiretos. Para o autor, o OI seria o constituinte precedido por qualquer preposição ${ }^{10}$. Por sua vez, em seus exemplos faz uso apenas das preposições de e $a$. Conforme sentenças abaixo:

(9) O sucesso do seu gesto não deu paz ao Lomba. ${ }^{11}$

Logo, o autor não faz distinção entre objeto indireto e demais complementos oblíquos, conforme exemplos ${ }^{12}$ :

(10) duvidava da riqueza da terra

(11) que ela afaste de ti aquelas dores

Em contrapartida, na descrição do PE moderno Mateus et al. (2003) caracterizam o OI no contexto dos verbos bitransitivos como o argumento introduzido pela preposição $a$, tipicamente com a função semântica de recipiente (alvo/meta) e fonte/origem. Além disso, esse complemento preposicionado tem o traço [+animado]. Quando é um pronome, apresenta a forma dativa. No caso da $3^{\mathrm{a}}$ pessoa, as formas lhe/lhes.

(12) a. O miúdo deu o brinquedo ao amigo. ${ }^{13}$

b. O miúdo deu-lhe o brinquedo.

Ou seja, Mateus et al. (2003) consideram bitransitivos apenas os verbos em que o OI apresenta essas características de expressão morfológica, a saber, serem antecedidos pela preposição $a$ e pronominalizado por lhe. Para os demais casos em que há dois complementos, sendo um o objeto direto e o outro o complemento preposicionado, a definição dada é de transitivo de dois lugares, sendo o complemento introduzido por preposição identificado como um complemento oblíquo.

\footnotetext{
${ }^{9}$ Neste trabalho, focamos apensas na caracterização do OI em semelhança com a proposta de Mateus (2003), para uma revisão detalhada dos compêndios gramaticais, confira Campos (2011)

${ }_{11}^{10}$ Além de Cunha e Cintra (1985), Brandão (1963) e Almeida (1999) também seguem a mesma definição.

${ }^{11}$ Exemplo extraído de Cunha e Cintra (1985, p.146)

${ }^{12}$ Exemplo extraído de Cunha \& Cintra (1985, p. 139).

${ }^{13}$ Exemplo extraídos de Mateus et al. (1991, p.231).
} 
Vejamos, pois, como as autoras distinguem os complementos preposicionados do OI, nos exemplos abaixo ${ }^{14}$ :

(13) a. O João deu um livro ao Pedro / O João deu-lhe um livro - objeto indireto

b. Ele partilhou o almoço com o amigo / Ele partilhou o almoço com ele complemento oblíquo

Além do complemento preposicionado, segundo elas, as relações oblíquas englobam também os adjuntos e expressam diferentes relações semânticas, entre elas, instrumento, beneficiário, tempo, duração, locativo, direcional, causa, fim; observáveis nos exemplos abaixo $^{15}$ :

(14) a.O meu amigo pintou esse quadro para a Maria. (beneficiário)

b.Tenho de sair já para não perder o avião. (fim)

c.O João cortou-se com o abre-latas. (instrumento)

Esses constituintes poderiam ser introduzidos por uma preposição, que marcaria sua função semântica. Entre aqueles que selecionam a preposição com, temos: confundir, partilhar, repartir; a preposição de: afastar, aproximar, esconder; em: converter, enfiar; a preposição por: distribuir, substituir, trocar. Diferentemente do OI que pode ser pronominalizado por lhe, os complementos oblíquos podem ser pronominalizados pelas formas tônicas ele/eles, ela/elas.

Essa categorização apesar de, como dito, referir-se ao PE moderno, assemelha-se as descrições feitas por Câmara Júnior (2002), Rocha Lima (2001) e Bechara (2002) ${ }^{16}$ os quais também fazem uma distinção entre as duas funções.

O que vemos, então, é que as gramáticas que normalmente servem de base ao ensino de português apresentam o objeto direto como "o complemento não encabeçado por

\footnotetext{
${ }^{14}$ Exemplos retirados de Mateus et al. (2003, p. 296 e 289)

${ }^{15}$ Exemplos do PE retirados de Mateus et al. (2003, p. 234)

${ }^{16}$ Castilho (2010) propõe, em sua gramática descritiva do PB, uma descrição do OI também com base em Mateus et al. (2003). Tendo o OI, portanto, as seguintes características:

(i) são proporcionais aos pronomes dativos $m e$, te, the

(ii) são preenchidas por sintagma preposicionado nuclear por $a$ e para,

(iii) a construção em que figuram não é conversível à voz passiva.

(iv) podem coocorrer juntamente com o objeto direto

(v) o papel temático é, em geral, beneficiário.

(vi) sua colocação de base é após o verbo, se houver OD, após este.

O linguista designa, ainda, os complementos oblíquos como sendo aqueles proporcionais à expressão preposição

+ pronome pessoal/ advérbio dêitico/ demonstrativo neutro.
} 
preposição necessária", enquanto o indireto é "encabeçado por preposição necessária" (cf. Bechara, 2002, p. 205), conforme os exemplos abaixo.

(15) a. A faxineira limpou a cozinha com muito esmero (objeto direto)

b. Não falei a meus amigos durante o jantar (objeto indireto)

No entanto, os três autores consideram como OI "legítimo" o termo que recebe as mesmas características morfológicas daquelas definidas por Mateus et al. (2003). Para outros casos em que o complemento é precedido por preposição, eles apontam diferentes soluções ${ }^{17}$. Conforme tabela abaixo:

Tabela 4 - A categorização do OI de acordo com Mateus (2003), Câmara Júnior (2002), Rocha Lima (2001) e Bechara (2002)

\begin{tabular}{|c|c|c|}
\hline Autor & $O I$ & Outros complementos preposicionados \\
\hline $\begin{array}{l}\text { Mateus et al. } \\
(2003)\end{array}$ & $\begin{array}{l}\text { OI } \\
\text { - } \text { pronominalizado em lhe } \\
\text { - aparece imediatamente à direita do } \\
\text { objeto direto; adjacente ao verbo, } \\
\text { se for um pronome clítico ou } \\
\text { imediatamente à direita do verbo } \\
\text { se o objeto direto for um sintagma } \\
\text { nominal pesado ou uma frase. }\end{array}$ & $\begin{array}{l}\text { Complemento oblíquo } \\
\text { - argumentos obrigatórios } \\
\text { opcionais, como os adjuntos } \\
\text { adverbiais }\end{array}$ \\
\hline $\begin{array}{l}\text { Câmara } \\
\text { Júnior (2002) }\end{array}$ & $\begin{array}{l}\text { OI stricto sensu } \\
\text { - introduzido por preposição } a \text {; } \\
\text { - pronominalizado em lhe. }\end{array}$ & $\begin{array}{l}\text { Objeto indireto lato sensu } \\
\text { - pode ser regido de uma preposição } \\
\text { diferente de } a \text {; } \\
\text { - admite a substituição por um } \\
\text { pronome oblíquo (que se prende a } \\
\text { preposição regida pelo verbo, como, } \\
\text { por exemplo, em "precisamos dele" } \\
\text { ou "assistimos a ele"). }\end{array}$ \\
\hline
\end{tabular}

\footnotetext{
${ }^{17}$ Salvo Bechara (2002) que propõe uma descrição bastante próxima de Rocha Lima (2001).
} 


\begin{tabular}{|c|c|c|}
\hline Autor & $O I$ & Outros complementos preposicionados \\
\hline $\begin{array}{l}\text { Rocha Lima } \\
\text { (2001) }\end{array}$ & $\begin{array}{l}\text { OI } \\
\text { - introduzido por preposição } a \text {, algumas } \\
\text { vezes para; } \\
\text { - pronominalizado em lhe; } \\
\text { - impossibilidade de transformação para } \\
\text { - } \text { a forma passiva; } \\
\text { - a que se destina a ação verbal. }\end{array}$ & $\begin{array}{l}\text { Complemento relativo } \\
\text { - liga-se ao verbo por uma preposição } \\
\text { determinada (a, com, de, em, etc.); } \\
\text { - distingue-se do objeto indireto por } \\
\text { não representar a pessoa ou coisa a } \\
\text { que se destina a ação e por não } \\
\text { corresponder na terceira pessoa às } \\
\text { formas pronominais átonas lhe/lhes, } \\
\text { mas às formas tônicas ele, ela. }\end{array}$ \\
\hline $\begin{array}{l}\text { Bechara } \\
(2002)\end{array}$ & $\begin{array}{l}\text { OI } \\
\text { - introduzido por preposição } a ; \\
\text { - } \text { pronomizalizado em lhe; } \\
\text { - entidade [+ animado]; } \\
\text { - a que se destina a ação verbal. } \\
\text { - entre um termo essencial e um } \\
\text { - } \text { adjunto; } \\
\text { menos valor argumental, na } \\
\text { contraposição com o objeto direto }\end{array}$ & $\begin{array}{l}\text { Complemento relativo } \\
\text { - introduzido por preposição, } \\
\text { - comutável pelos pronomes pessoais } \\
\text { tônicos ele, ela, eles, elas }\end{array}$ \\
\hline
\end{tabular}

Como podemos observar pela tabela, há um consenso na descrição do OI. Os autores selecionados atribuíram as propriedades identificadoras do OI como sendo a pronominalização pelo clítico lhe e precedidas pela preposição $a$.

Portanto, nos casos específicos de verbos que tem dois complementos, um objeto direto e um complemento antecedido por preposição diferente de $a$, este último é tratado com diferentes nomenclaturas, a saber: em Mateus et al. (2003), complemento oblíquo; em Rocha Lima (2001) e Bechara (2002), complemento relativo e em Câmara Júnior (2002), objeto direto lato sensu.

Podemos, pois, verificar que as propriedades do OI, a saber, constituinte introduzido pela preposição $a$ e pronominalizado pelo lhe/lhes na $3^{\text {a }}$ pessoa é, comum aos três autores, e, curiosamente, todos têm os mesmos critérios utilizados por Mateus et al. (2003) para descrever o PE. Na próxima seção, nosso objetivo é mostrar os trabalhos acadêmicos que estudaram exatamente esse português em uso os quais apontam variação e mudança na realização dessa função. 


\subsection{A descrição do PB do OI nos trabalhos acadêmicos}

Depois da abordagem realizada na seção anterior, resta-nos uma pergunta: A descrição apresentada pelos gramáticos brasileiros baseada no PE seria adequada para os fatos do PB? Nesta seção mostraremos que as duas propriedades marcantes do OI - antecedido por $a$ e pronominalizado por lhe - destacadas por esses gramáticos, não expressam a realidade do PB

Antes de apresentarmos os fatos do OI no PB é necessário fazer um recorte nos contextos verbais em que eles podem ocorrer. Optamos por esta delimitação porque um dos nossos objetivos é observar a competição entre as preposições a e para nas redações dos alunos. Assim, mostraremos como se manifesta o OI no PB no contexto dos chamados verbos de transferência e movimento tal como formulado em Berlinck (1996).

A autora propõe a divisão dos verbos de transferência e movimento a partir de quatro contextos diferentes: transferência material; transferência verbal e perceptual; movimento físico e movimento abstrato.

(i) Transferência material - Verbo prototípico: dar

Propriedades sintático-semânticas: $\mathrm{N}_{0}$ [+/- animado], $\mathrm{N}_{1}$ [(+)/-animado], $\mathrm{N}_{2}\{$ a, para, de\} [+/-animado]

Inclui os verbos: alugar, atribuir, confiar, devolver, distribuir, emprestar, entregar, fornecer, legar, mandar, oferecer, pagar, passar, restituir, transferir.

(16) [Eles $]_{\mathrm{N} 0}$ Não entregaram a mercadoria ${ }_{\mathrm{N} 1}$ ao comprador ${ }_{\mathrm{N} 2}$

As construções de transferência material também podem indicar um sentido reverso, em que $\mathrm{N}_{1}$ ao invés de entrar no domínio de posse de $\mathrm{N}_{2}$, é retirado desse domínio. Os verbos em que ocorrem essas construções são: arrebatar, arrancar, comprar, confiscar, cortar, emprestar, evitar, pedir, furtar, roubar, subtrair, suprimir, tirar, tomar.

(ii) Transferência verbal e perceptual - Verbo prototípico: dizer

Propriedades sintático-semânticas: $\quad \mathrm{N}_{0}$ [+/-animado], $\mathrm{N}_{1}$ [-animado], $\mathrm{N}_{2}\{\mathrm{a}$, para $\}$ [+animado] 
Inclui os verbos: aconselhar; anunciar; assegurar; augurar; confessar; cantar; ensinar; escrever; falar; jurar; narrar; ordenar; perguntar; prometer; protestar; provar; repetir; responder; sugerir; telefonar.

\section{Pedro $_{\mathrm{N} 0}$ disse para seus colegas $\mathrm{N}_{\mathrm{N} 2}$ que o diretor estava doente ${ }_{\mathrm{N} 1}$}

Esse grupo de verbos não envolve transferência de entidades concretas, mas somente a transferência abstrata ou o efeito de um ato de comunicação em que $\mathrm{N}_{0}$ transfere para $\mathrm{N}_{2}$ algum conhecimento.

(iii) Movimento físico - Verbo prototípico: levar

Propriedades sintático-semânticas: $\mathrm{N}_{0}$ [+/-animado], $\mathrm{N}_{1}$ [+/-animado], $\mathrm{N}_{2}$ \{a, para, de, em $\}[+/-$ animado]

Inclui os verbos: acrescentar; atirar; conduzir; dirigir; encaminhar; instilar; lançar; pôr; trazer.

(18) No aniversário do amigo $[\varnothing]_{\mathrm{N} 0}$ levou-lhe $e_{\mathrm{N} 2} \underline{\mathrm{um}}$ livro $_{\mathrm{N} 1}$.

Segundo Berlinck, os verbos que compõem esse grupo explicitam uma extensão da ideia de transferência, porque complementam esta noção com um movimento físico. $\mathrm{O}$ sentido prototípico é um movimento físico de transferência em direção a uma meta/alvo transferência de $\mathrm{N}_{1}$ para $\mathrm{N}_{2}$. Quando expresso por uma entidade [- animada], o objeto meta/alvo tem um significado de locativo. Quando expresso por uma entidade [+ animada] tem conotação beneficiário.

(iv) Movimento abstrato - Verbo prototípico: submeter.

Propriedades sintático-semânticas: $\mathrm{N}_{0}$ [+/- animado], $\mathrm{N}_{1}$ [+/- animado], $\mathrm{N}_{2}\{$ a, para, em $\}$ [+/- animado]

Inclui os verbos: acrescentar; adaptar; anexar; atribuir; conferir; consagrar; dedicar; destinar; filiar; imputar; incorporar; juntar; pôr; sensibilizar; submeter; subordinar; trazer.

(19) Os trabalhos ${ }_{\mathrm{N} 0}$ lhe $e_{\mathrm{N} 2}$ foram submetidos ontem. 
Estes verbos expressam a ideia de movimento abstrato. Assim como os anteriores, este grupo implica certo tipo de movimento, sem transferência. Observa-se uma aproximação abstrata entre uma entidade e um estado, um sentimento, uma ideia ou outra entidade.

A autora menciona, ainda, o dativus commodi/incomodi; o dativo possessivo e o dativus ethicus.

Moretti (2010), com base na tipologia verbal de Berlinck, traz uma exemplificação com dados da internet e confere a variação entre os usos variados da preposição $a$ e para no PB. O mesmo levantamento não é realizado para o OIs pronominais. Reproduzimos abaixo alguns de seus exemplos relativos a cada contexto ${ }^{18}$.

(i) Verbos de Transferência Material ou Abstrata

(20) a. Dona de lotérica conta como devolveu bilhete premiado para apostadora

b. Depois de encontrar no lixo a aposta vencedora, a dona da lotérica devolveu o segundo bilhete premiado a Ilda Pazetto, 55 anos

(ii) Verbos de Transferência Verbal

(21) a. Jongo de Itapemirim é Patrimônio Cultural do Brasil

Foi o que comunicou para os jongueiros de Mestre Bento, a diretora de Turismo de Itapemirim, Lúcia Sampaio

b. João Castro Neves comunicou ao governador a antecipação dos investimentos da Ambev em Minas

(iii) Verbos de Transferência Perceptual

(22) a. Os músicos mostraram para os jovens a música de raiz, músicas de viola e o popular regional

b. Eles mostraram ao público os maiores desafios para testes de dispositivos multimedia e as soluções da National Instruments para testes de áudio e vídeo analógico e digital

(iv) Verbos de Movimento Físico

(23) a. Consumo de sushi transferiu genes de bactéria para humanos

b. Igreja transferiu padre suspeito de abuso sexual ao Brasil

(v) Verbos de Movimento Abstrato

(24) a. Durante o Geração Digital aconteceram as Oficinas, atividades monitoradas fora do palco. Destaque entre os que participaram do evento, as oficinas transmitiram conhecimentos valiosos para o futuro profissional de crianças e adolescentes.

\footnotetext{
${ }^{18}$ Exemplos retirados de Moretti (2010, p. 36)
} 
b. Esse sistema tem esse nome devido aos hindus que o inventaram e devido aos árabes, que o transmitiram para a Europa Ocidental.

Portanto, os dados apontam que há variação entre as preposições $a$ e para na língua escrita nos mesmos contextos verbais.

Observe-se ainda que a variação $a$ e para está realmente restrita aos verbos de transferência e movimento ${ }^{19}$. Como Armelin (2011) afirma, esta variação não se apresenta com verbos similares aos anteriores, no sentido de selecionar dois argumentos, mas que não expressam transferência ou movimento. ${ }^{20}$. Conforme exemplos abaixo extraídos de Armelin (2011, p. 25)
a. * O João construiu a casa ao Pedro
b. O João construiu a casa para o Pedro
c. *A Maria cozinhou o bolo ao Pedro
d. A Maria cozinhou o bolo para o Pedro

Como se trata de dados da intuição, possivelmente em textos muito formais ainda encontremos a variação com a preposição $a$. De qualquer forma, em estudos sobre os usos cultos do PB que veremos a seguir, diacronicamente houve uma queda dessa preposição em relação ao para. Sendo, portanto, a realização precedido por $a$, adquirida na escola.

A autora também ressalta que a preposição $a$ forma sentenças não-ambíguas em que a relação semântica se estabelece entre os complementos do verbo explicitados na sentença. No entanto, o uso da preposição para gera, tanto no PB quando no PB moderno, sentenças semanticamente ambíguas. Verificáveis abaixo, também extraídos de Armelin (2011, p. 26)

(26) O João deu o dinheiro para o pai.

Contexto (a): O pai estava precisando de dinheiro para pagar a parcela do carro.

O João tinha um dinheiro sobrando, então o João deu o dinheiro para o/ ao pai.

Contexto (b): O pai precisava dar o dinheiro para a Maria, mas justo na hora em que a Maria passou para receber o dinheiro, o pai não estava em casa, então o João deu o dinheiro para o pai.

Logo, apesar de não fazer parte do vernáculo, o letrado adquire a preposição $a$, considerada padrão, por meio da escolaridade.

\footnotetext{
${ }^{19} \mathrm{Na}$ verdade, esta variação com verbos de transferência e movimento oscila. Por exemplo, é mais comum encontrar variação em verbos como dar e oferecer do que com escrever e ler.

${ }^{20}$ Torres Morais e Berlinck (2007) denomina esses verbos como verbos de criação, tais como: desenhar, pintar, alugar, preparar, cozinhar, bater (um bolo) etc.
} 
Da mesma forma, outros trabalhos apontam para o decréscimo e quase desaparecimento do clítico de $3^{\mathrm{a}}$ pessoa, lhe/lhes, do vernáculo do $\mathrm{PB}$, substituído por a/para ele/ela. Em pesquisa cujo corpus envolveu revistas femininas, Torres Morais e Berlinck (2006) identificaram essa ausência do clítico dativo de $3^{a}$ pessoa, o qual foi suplantado pelo uso das preposições a/para seguidas de pronomes fortes.

(27) a. Se o seu namorado merece mais do que rosas, dê para ele os melhores botões. Camisas Dudalina por Fernando de Barros.

b. ...o mesmo respeito que merecem os professores de seus alunos, que dão $a$ eles, lamentavelmente, um péssimo exemplo.

Finalmente temos a realização nula do OI nulo,

$$
\text { João entregou [Ø] flores na casa da Maria }{ }^{21}
$$

Diante deste cenário, propomos que a definição de objeto indireto para o PB deveria ser reformulada para os seguintes termos:

1) O OI no contexto de verbos bitransitivos identifica-se como um argumento verbal, introduzido pelas preposições $a$ e para.

2) O OI de $3^{a}$ pessoa pode ser pronominalizado pelas formas clíticas lhe/lhes, pelos pronomes fortes introduzidos por $a$ ou para, e pela forma nula fonologicamente

Essas variações na realização do OI no PB - decréscimo no uso de the e substituição da preposição a por para no SP - tem sido documentada em muitos trabalhos, com base em corpus histórico variado como veremos na próxima seção.

\subsection{O OI em uso - diacronia}

Nessa seção serão apresentados os resultados quantitativos do PB falado e escrito, os quais nos permitem verificar um quadro de fenômeno em variação no que se refere ao preenchimento do OI.

\footnotetext{
${ }^{21}$ Exemplo retirado de Armelin (2011, p. 98)
} 
Estudos de língua escrita e falada de diferentes regiões do Brasil apontam mudanças em dois aspectos gramaticais relacionados à realização do dativo de $3^{\mathrm{a}}$ pessoa: diminuição do uso da preposição $a$, a qual é substituída pela preposição para nos SP e decréscimo no uso do clítico dativo de $3^{\text {a }}$ pessoa lhe $(s)$, sendo este substituído pelo pronome lexical, pelo pronome forte antecedido de a/para ou, ainda, pelo objeto indireto nulo fonologicamente, como se observa nos exemplos abaixo.
a. João deu o livro para/pra Maria
b. João deu o livro a ela/ para/pra ela
c. João deu ela o livro
d. João enviou o livro ${ }^{22}$

Em um percurso diacrônico da expressão pronominal do OI com dados extraídos de relatos, cartas (séc. XVIII) e peças de teatro (séc. XIX) (cf. Berlinck, 2001), percebe-se, na primeira metade do século XVIII uma predominância do uso do pronome clítico e nenhuma ocorrência de pronome introduzido por preposição. Já no século XIX, a percentagem de objeto nulo chega a $30 \%$, enquanto o uso dos clíticos diminui $4 \%$.

Gráfico 5 - Variantes de OI de $3^{\mathrm{a}}$. pessoa no PB dos séculos XVIII e XIX

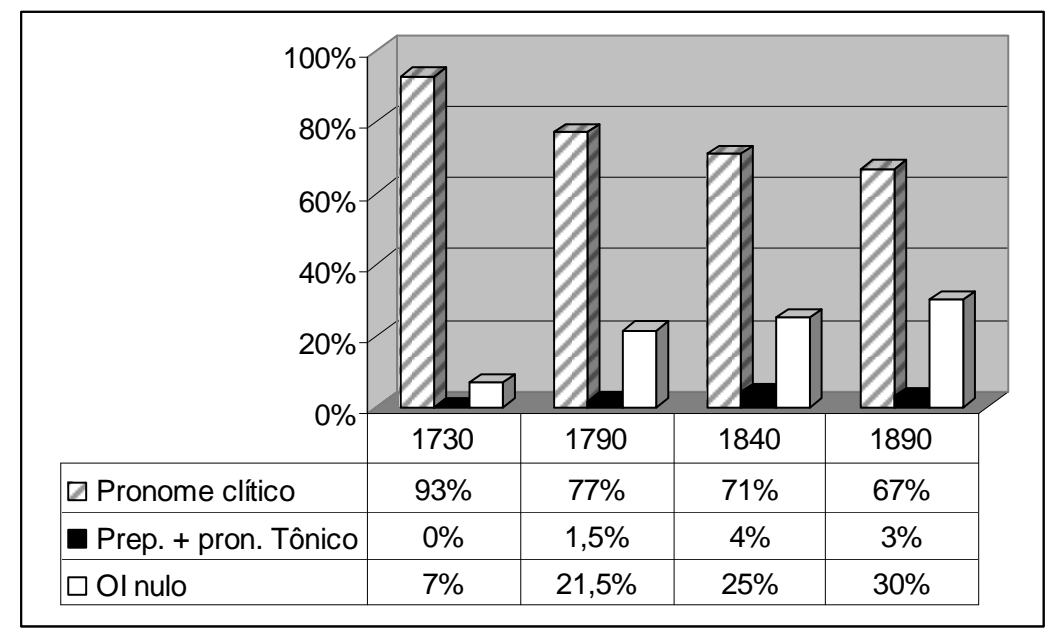

(Berlinck, 2001, p. 87)

Do início do século XVIII para o final do século XIX, o que se observa nos dados é a queda de $26 \%$ no uso do pronome clítico. Por outro lado, é possível verificar o progressivo avanço no uso do OI nulo, principalmente no século XIX. Observamos essa variação nos exemplos abaixo:

\footnotetext{
${ }^{22}$ Extraído de Torres Morais (2006).
} 
(30) Deixa estar: tua mãe chegando, vou dizer-lhe, para ela te dar umas palmadas!... Eu vi sim! A mamãe chegando, eu vou contar $[\varnothing]^{23}$

Essa tendência ao desaparecimento do clítico dativo perdura durante o século $\mathrm{XX}$, conforme análise realizada por Torres Morais e Berlinck (2007) em textos de natureza semiformal do Fórum de Debates do Estado de São Paulo - On-line, entre 2003 e 2004, em que foram obtidos os seguintes resultados: 47,5\% de OI pronominais expresso por clíticos dativos; $11 \%$ na forma de pronome lexical (Prep + pronome) e 41,5\% como objeto nulo. $\mathrm{O}$ índice ainda elevado de clítico explica-se devido a natureza semiformal do corpus. Abaixo, verificamos um exemplo extraído desse corpus.

(32) Waltinho auau...não fique estressado assim, pode lhe fazer mal. Apenas disse para vc não copiar artigos do jornal local para impressionar os demais leitores, sugiro que procure o tal jornal e peça lhes um forum exclusivo... ACORDA POVINHO

Se na variante escrita já se constata essa queda acentuada no uso dos clíticos de $3^{\mathrm{a}}$ pessoa, na fala esses índices são ainda mais altos. Berlinck (1997), analisando a fala de jovens curitibanos, constata que apenas $1 \%$ dos casos de dativo de $3^{\text {a }}$ pessoa ocorreu na forma de pronome clítico. A tabela abaixo aponta o contraste entre as três pessoas gramaticais observado nesse estudo:

Tabela 5 - OI anafórico na fala de curitibanos - Percentuais e número de ocorrências

\begin{tabular}{|l|l|l|l|l|}
\hline & OI nulo & OI clítico & OI oblíquo & Total \\
\hline 1a pessoa & $60 \%(117)$ & $32,5 \%(64)$ & $7,5 \%(15)$ & $(196)$ \\
\hline 2a pessoa & $33 \%(20)$ & $52 \%(31)$ & $15 \%(9)$ & $(60)$ \\
\hline 3a pessoa & $76 \%(141)$ & $1 \%(1)$ & $23 \%(43)$ & $(185)$ \\
\hline
\end{tabular}

(Berlinck, 1997, p. 34)

Gomes (2003), em análise do mesmo fenômeno na fala de cariocas (corpus do Programa de Estudo do Uso da Língua - PEUL), observou a mesma ausência de uso de pronomes clíticos dativos de $3^{\mathrm{a}}$ pessoa.

Outro fenômeno em mudança relaciona-se à diminuição no uso de $a$ e o aumento da utilização de para. Em contextos do séc. XVIII com verbos bitransitivos, as ocorrências de SN apresentavam uso quase categórico da preposição a (95\%). Já a preposição para introduziam complementos que não constituem objetos indiretos típicos. (cf. Berlinck, 2001)

\footnotetext{
${ }^{23}$ Exemplos retirados de Berlinck (2001)
} 
No século XIX, a autora observa o predomínio da preposição $a$ nos mesmos contextos verbais, mas com uma tendência à diminuição do emprego dessa preposição.

A tabela abaixo referente ao estudo de Torres Morais e Berlinck (2006), baseia-se em estudo de Berlinck (2000) e confirma esse predomínio no uso de $a$.

Tabela 6 - Uso da preposição $a$ e para na realização do OI

\begin{tabular}{|c|c|c|}
\hline Preposição & \multirow{2}{*}{$\mathbf{A}$} & \multirow{2}{*}{ PARA } \\
\hline Momento & & \\
\hline XIX $-1^{\mathrm{a}} \cdot$ metade & $93 \%(25 / 27)$ & $7 \%(2 / 27)$ \\
\hline XIX $-2^{\mathrm{a}} \cdot$ metade & $83 \%(29 / 35)$ & $17 \%(6 / 35)$ \\
\hline
\end{tabular}

(Torres Morais e Berlinck, 2006, p. 36)

Nesta primeira metade do século XIX, a preposição para aparece introduzindo complementos de verbos de transferência material, conforme o exemplo abaixo extraído de Berlinck (2001):

(33) Esta carta que acabam de trazer para o senhor.

Nota-se que o cenário atual reflete um processo gradual de substituição da preposição a por para já atestado por vários estudos. Ao contrário, porém, do que se verificou com relação à perda do pronome clítico, o declínio da preposição $a$ começa a se manifestar essencialmente no século XX. Os trabalhos mais recentes já comprovam a supremacia no uso da preposição para em detrimento de $a$ mesmo em textos formais, como mostra o exemplo 34. (conf. Torres Morais e Berlinck, 2007)

(34) a. Quem vende MacDoland's e Coque-Cola para nossas crianças deve receber o mesmo tratamento oferecido aos suspeitos de prática de terrorismo e narcotráfico que aportam na terra deles. Abaixo Al Capone, viva o alface!

O mesmo progresso de substituição do a e para pode ser visualizado no gráfico 06 abaixo, extraído de Torres Morais e Berlinck, 2007. 
Gráfico 6 - Uso da preposição $a$ e para na realização do OI

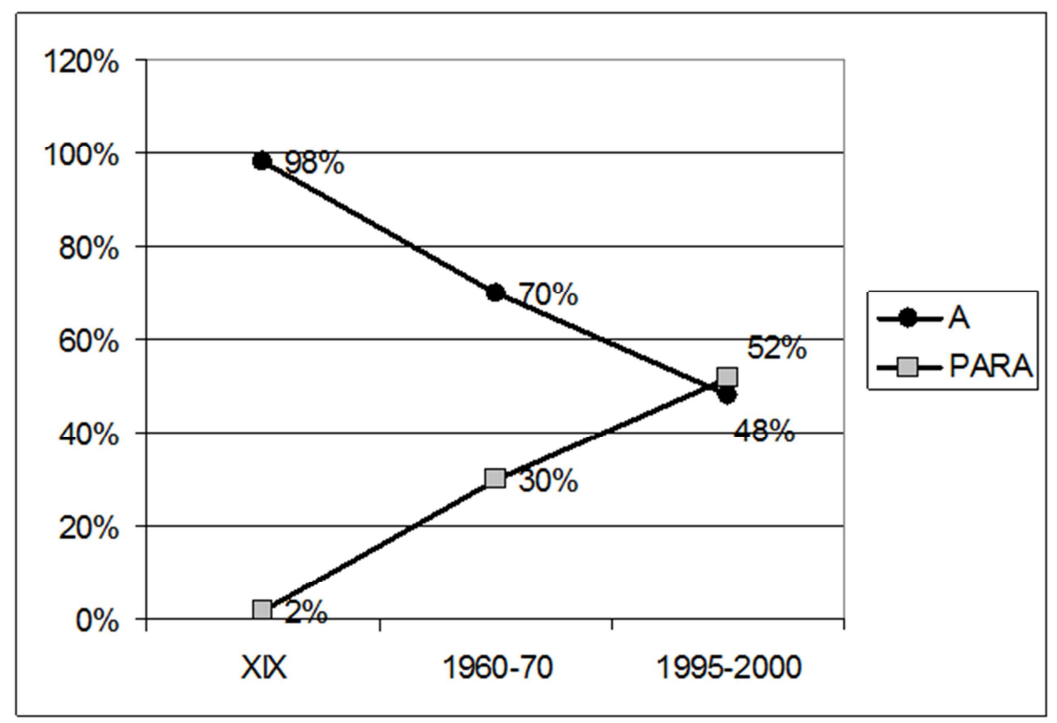

(Torres Morais e Berlinck, 2007, p.88)

De maneira geral, o que as pesquisas comprovam é que o PB sofreu transformações em seu sistema gramatical, o que culminou na perda da propriedade de expressar morfologicamente o OI, distanciando-se ainda do PE na realização do OI por meio do clítico dativo e no uso da preposição $a$ antecedendo o SN.

\subsection{O "ensino" do OI}

Como já apontado na seção anterior, os trabalhos acadêmicos sobre o PB registram, ao longo dos séculos, a substituição do clítico dativo por uma categoria vazia ou por um SP anafórico, sendo este com a forma tônica do pronome ou com SN pleno (cf. Gomes, 1996; Silveira, 2000; Freire, 2000).

Se esta variação já foi comprovada tanto na fala como na escrita, pergunta-se: qual o papel da escola no resgate das formas conservadoras ou na propagação das variantes? Em que contextos o falante culto do PB opta por cada uma das variantes?

Sabemos que é na oralidade que as mudanças manifestam-se mais rapidamente, já que a fala é menos conservadora do que a escrita e, a princípio, não exige a formalidade e a rigidez dos registros escritos. Na observância de corpus centrado na fala culta brasileira, o que se comprova é essa total rejeição do clítico dativo, conforme tabela abaixo extraída de Freire (2000), em detrimento da forma nula e do SP anafórico. 
Tabela 7 - Função dativa na língua oral: distribuição dos dados segundo a variante usada

\begin{tabular}{|c|c|c|c|c|c|}
\hline \multicolumn{2}{|c|}{ Clítico } & \multicolumn{2}{c|}{ SP anafórico } & \multicolumn{2}{c|}{ Objeto nulo } \\
\hline----- & ----- & $9 / 14$ & $64 \%$ & $5 / 14$ & $36 \%$ \\
\hline
\end{tabular}

Silveira (2000), em trabalho sobre a realização do dativo na fala de informantes de Florianópolis, com nível fundamental e médio, registra apenas $2 \%$ de clítico dativo na terceira pessoa em oposição a $98 \%$ do SP anafórico representado pelo pronome tônico, o que aponta um fenômeno de perda do clítico na expressão do dativo anafórico de terceira pessoa, no dialeto florianopolitano.

Como relatado na seção anterior, Berlinck (1997) analisou as condições de ocorrência do objeto indireto, a partir de dados obtidos por meio de corpus compreendido por fala de jovens universitários curitibanos e de adultos cariocas. Os resultados também apontaram para a queda do clítico lhe e da preposição $a$ em favor do uso da forma nula e da preposição para, respectivamente. A autora detectou alto índice da OI nulo (71\%) e baixíssimo índice de clíticos (1\%), observou, ainda, que o SP é encabeçado preferencialmente pela preposição para $(28 \%)$ e que na fala de curitibanos a preposição $a$ teve uso menos frequente que na fala dos cariocas ( $40 \%$ e $70 \%$ respectivamente).

Diante desses resultados, comprovamos que o pronome clítico não faz parte do vernáculo do falante culto brasileiro. Ou seja, apesar deste falante receber, ao menos, 12 anos de aprendizado básico formal do idioma na escola; sendo, pois, submetido ao "ensino" da forma de prestígio: o clítico, ele não o realiza em sua fala cotidiana.

$\mathrm{Na}$ escrita, esta situação se repete. Os resultados sobre a função dativa realizada em textos de jornais e revistas, meios que, a priori deveriam utilizar a língua formal de prestígio apontam que a variante considerada culta pela tradição constitui pouco mais de um quarto do total de dados, enquanto as demais somam 74\%. (conf. Freire, 2005; 2011)

Tabela 8 - Função dativa na língua escrita: distribuição dos dados segundo a variante usada.

\begin{tabular}{|c|c|c|c|c|c|}
\hline \multicolumn{2}{|c|}{ Clítico } & \multicolumn{2}{c|}{ SP anafórico } & \multicolumn{2}{c|}{ Objeto nulo } \\
\hline $41 / 155$ & $26 \%$ & $65 / 155$ & $42 \%$ & $49 / 155$ & $32 \%$ \\
\hline
\end{tabular}

\footnotetext{
${ }^{24} \mathrm{O}$ estudo de Freire (2005) é importante, mas faz-se necessária uma ressalva quanto ao número excessivamente reduzido de dados analisados.
} 
Esses resultados sinalizam que, na escrita brasileira,

as estratégias alternativas ao pronome dativo se encontram infiltradas de maneira avassaladora na expressão do objeto indireto anafórico de terceira pessoa, o que evidencia uma influência limitada do ensino escolar na recuperação do clítico dativo no registro escrito.

(Freire, 2011, p. 380)

Além disso, a presença de formas variáveis identificadas especialmente em textos escritos é um indício muito significativo de que se está diante de um processo em fase avançada de implementação, pois esse tipo de registro é o último estágio atingido pelas mudanças.

Para Freire (2005), há uma forte relação entre formalidade/letramento na realização do objeto indireto. Ao analisar a língua escrita, o autor verificou que a constância no uso das variantes em função dativa modifica-se de acordo com o grau de letramento, como se pode observar na figura.

Gráfico 7 - Variantes em função dativa no PB, segundo o continuum oralidade - letramento

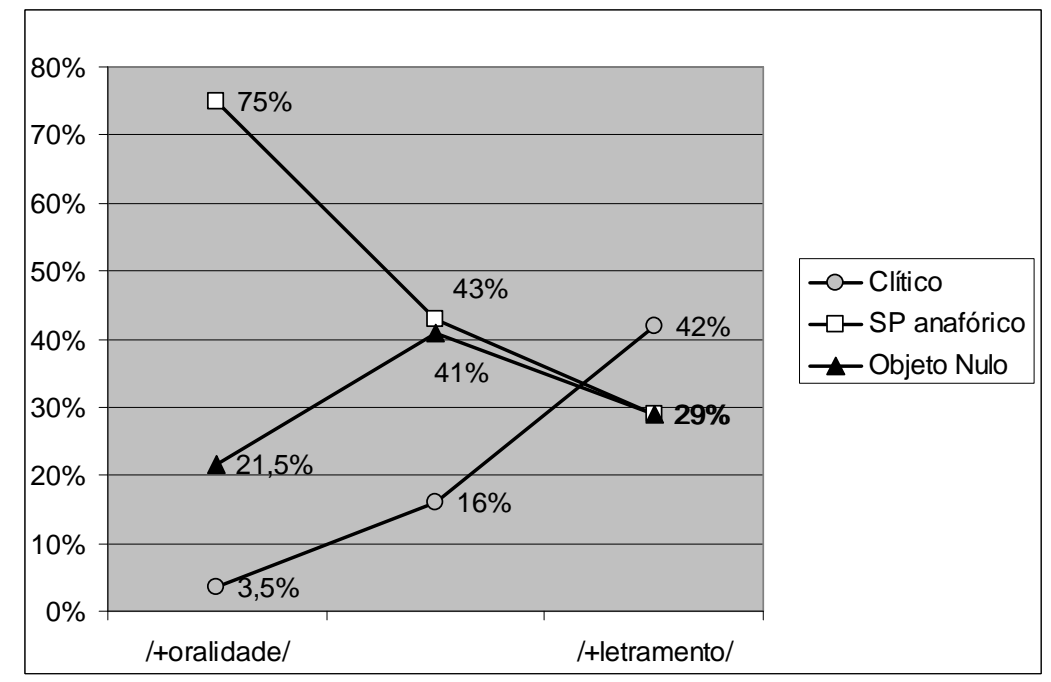

(Freire, 2005, p.141)

Para a classificação dos textos, Freire utilizou o seguinte critério:

- [+ oralidade - letramento]: histórias em quadrinhos; já que estes tentam reproduzir a fala. 
- [+oralidade, + letramento]: crônicas, trechos de fala em reportagem, entrevistas; textos que mesclam a língua normativa com a oralidade.

- $[-$ oralidade + letramento]: reportagens, editoriais, críticas de livro/filme, artigos de opinião, gêneros em que há maior rigidez no uso da escrita padrão.

O estudo evidenciou, ainda, as divergências entre o PB e a variante europeia no que se refere à realização do OI anafórico, conforme tabela abaixo.

Tabela 9 - Função dativa: distribuição dos dados computados segundo a variante usada

\begin{tabular}{|l|c|c|c|c|c|c|}
\hline Variedades & \multicolumn{2}{|l|}{ Clítico } & \multicolumn{2}{l|}{ SP anafórico } & \multicolumn{2}{l|}{ Objeto nulo } \\
\hline PB & $41 / 155$ & $26 \%$ & $64 / 155$ & $42 \%$ & $49 / 155$ & $32 \%$ \\
\hline PE & $90 / 108$ & $83 \%$ & $3 / 108$ & $3 \%$ & $15 / 108$ & $14 \%$ \\
\hline
\end{tabular}

(Freire, 2005, p.59)

$\mathrm{Na}$ variedade brasileira, a forma considerada culta constitui apenas um quarto do total de dados. Na variedade europeia, essa mesma variante representa mais de $80 \%$ das ocorrências. Percebe-se que no PE as estratégias ao clítico se mostram irrisórias, enquanto no PB são maioria.

Esses dados comprovam que, pelo menos na variedade brasileira, as estratégias alternativas à variante considerada padrão do clítico dativo já foram assimiladas completamente na escrita, inclusive nos meios de comunicação.

Os resultados gerais podem ser mais bem visualizados a partir do seguinte gráfico:

Gráfico 8 - Função dativa - distribuição das variantes segundo a variedade do português 


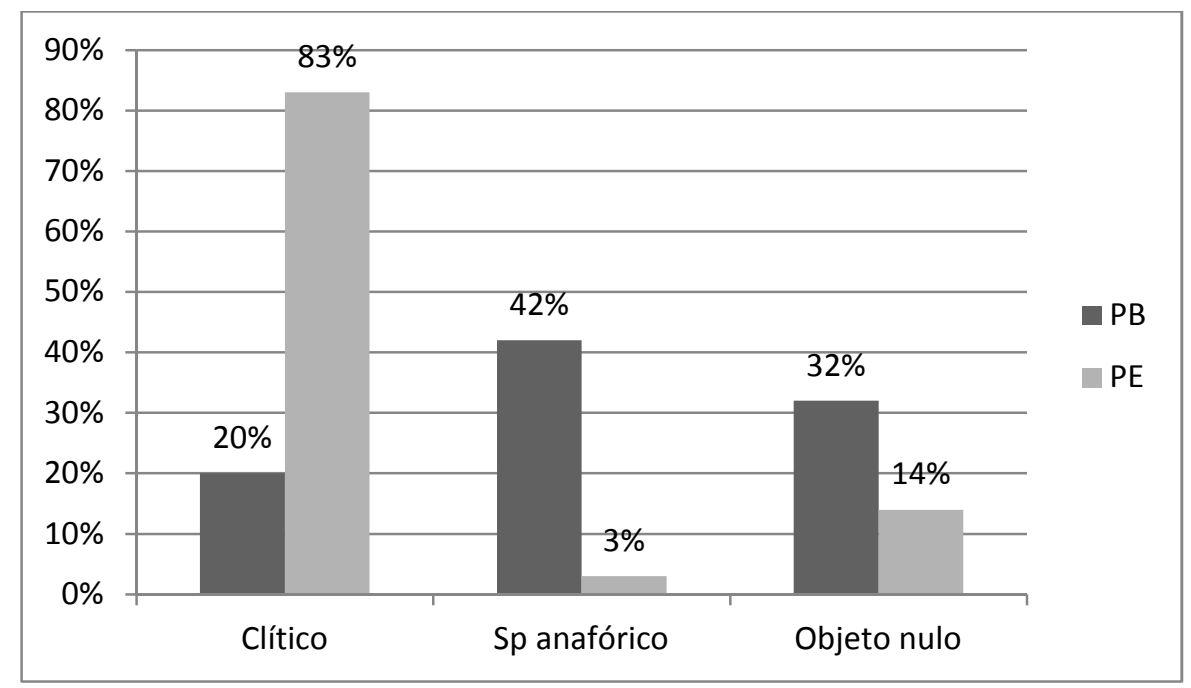

Confrontando o uso do clítico em PB e PE no continuum oralidade-letramento, confirma-se essa enorme distância entre a forma lusitana e a brasileira. Enquanto no PE há certo equilíbrio no uso do clítico tanto nos gêneros considerados mais orais quanto nos que requerem maior letramento, no PB há uma grande discrepância entre os valores.

Gráfico 9 - Distribuição das variantes clítico dativo em um continuum oralidade-letramento

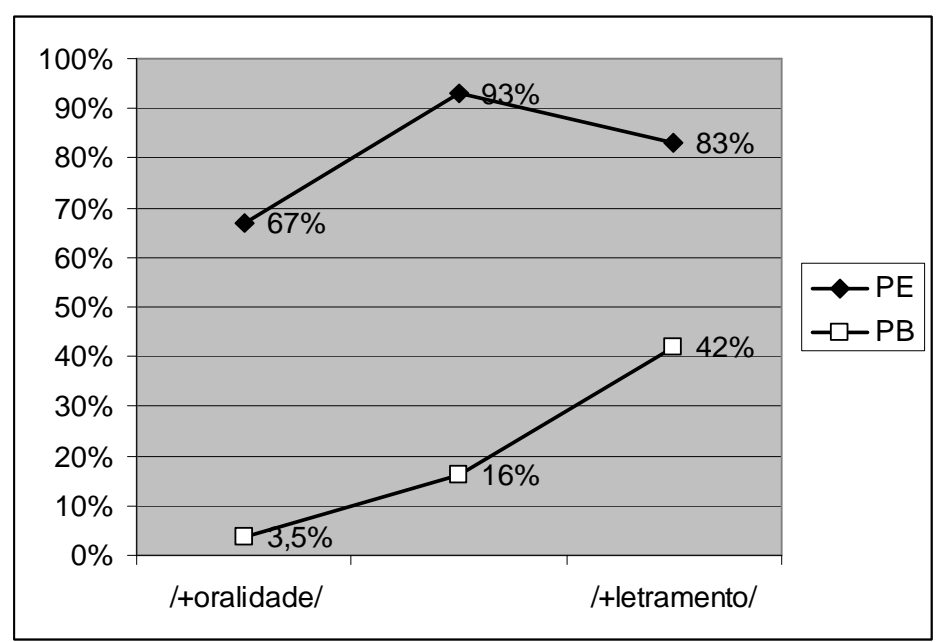

(Freire, 2005, p.165)

As diferenças entre o PB e o PE mostraram-se acentuadas: enquanto este revelou uma forte ocorrência do clítico ao longo de todo o contínuo oralidade-letramento, aquele apresentou um emprego mais elevado desse elemento somente no extremo de [+ letramento].

Comprova-se, portanto o abismo entre a variante europeia e o $\mathrm{PB}$, devido à implementação de estratégias alternativas à variante prescrita pela tradição na escrita 
brasileira. Ou seja, enquanto o clítico dativo faz parte do vernáculo do PE, no Brasil esta estratégia só é adquirida na escolaridade e utilizada em situações muito formais.

Para compreender como efetivamente a escola "ensina" essas formas mais valorizadas, Freire (2011) analisou as estratégias comumente usadas pelos livros didáticos. Para isso, o pesquisador parte de exemplos extraídos de redações de vestibular, portanto de indivíduos que já passaram por todo o processo da educação básica e constatou neste estudo a ineficácia das referidas estratégias quanto ao efeito desejado, o que suscita uma reflexão sobre as práticas adotadas pela escola na disciplina de Língua Portuguesa.

Podemos incluir nessa reflexão, os resultados encontrados por Santos (2007) em estudo realizado com alunos do Ensino Fundamental e Médio. O trabalho envolveu duas atividades com níveis de formalidade distintos e os resultados revelaram o uso da forma de prestígio em gêneros mais formais, conforme dados das tabelas abaixo.

Tabela 10 - Forma de preenchimento do OI - Atividade mais formal ${ }^{25}$

\begin{tabular}{|c|c|c|c|c|c|c|c|c|}
\hline & $5^{\mathrm{a}} \mathrm{EF}$ & $6^{\mathrm{a}} \mathrm{EF}$ & $7^{\mathrm{a}} \mathrm{EF}$ & $8^{\text {a }}$ EF & $1^{\circ} \mathrm{EM}$ & $2^{\circ} \mathrm{EM}$ & $3^{\circ} \mathrm{EM}$ & TOTAL \\
\hline & n. $\%$ & n. $\%$ & n. $\%$ & n. $\%$ & n. $\%$ & n. $\%$ & n. $\%$ & $\mathrm{n}$. \\
\hline CI & 17165,78 & 45080,35 & 28579,83 & 45479,51 & $58 \quad 98,31$ & 1965,52 & 5998,33 & 1496 \\
\hline SP & $93 \quad 35,22$ & 11019,65 & $\begin{array}{ll}72 & 20,17\end{array}$ & 11720,49 & 11,69 & $10 \quad 34,48$ & 11,67 & 404 \\
\hline
\end{tabular}

(Santos, 2007, p.70)

É significante observar que o clítico predomina em todas as séries escolares, em detrimento do SP, o qual tem índice maior na $5^{\mathrm{a}}$ série do E.F. A preferência pelo clítico pode encontrar justificativa no tipo de atividade que induz à formalidade.

$\mathrm{Na}$ análise dos clíticos utilizados, Santos identificou nos dados o uso do clítico acusativo em função de OI, mas em percentuais bastante baixos, com exceção das $1^{\mathrm{a}}$. e $3^{\mathrm{a}}$. séries do E.M., em que os índices ficam entre $40 \%$ e $25 \%$, respectivamente. Para o autor, tal fato pode caracterizar uma hipercorreção dos alunos na busca por preencher o OI, pois tais alunos têm o conhecimento de que o clítico caracteriza fortemente a linguagem mais formal.

Nestas séries, em teoria, os aprendizes estariam mais letrados do que os alunos de $5^{\text {a }}$ série do EF; no entanto, este processo de letramento oferecido pela escola ou não foi claro, ou não foi competente, ou o aluno apenas associa clítico a um uso estilístico, mais do que sintático.

(Santos, 2007, p. 71)

\footnotetext{
${ }^{25} \mathrm{O}$ aluno obtinha um texto com verbos e OD preenchidos e deveriam preencher ou não a lacuna do OI, visto que os verbos eram bitransitivos.
} 
Além disso, os dados também apontaram um maior índice da preposição $a$ em detrimento de para. Para o autor, esse índice também pode ser favorecido pela formalidade da produção.

\begin{abstract}
A preposição para não é preferida $\mathrm{e}$, ainda, nem concorre acirradamente com a preposição $a$ no preenchimento do OI. Esses resultados estão em conformidade com os de Gomes (2003) na medida em que se observa o maior grau de formalidade da preposição $a$. O tipo de atividade proposto (preenchimento de lacunas) parece privilegiar a opção mais formal.
\end{abstract}

(Santos, 2007, p. 73)

Por outro lado, em uma atividade em que os alunos visualmente tinham mais espaço para produzir, como o verso em branco da folha, os índices mostram-se divergentes.

Tabela 11 - Forma de preenchimento do OI - Atividade mais informal

\begin{tabular}{|c|c|c|c|c|c|c|c|c|}
\hline & $5^{a} \mathrm{EF}$ & $6^{a} \mathrm{EF}$ & $7^{\mathrm{a}} \mathbf{E F}$ & $8^{\mathrm{a}} \mathrm{EF}$ & $1^{\circ} \mathrm{EM}$ & $2^{\circ} \mathrm{EM}$ & $3^{\circ} \mathrm{EM}$ & TOTAL \\
\hline & $\%$ & n. $\%$ & n. $\%$ & n. $\%$ & n. $\%$ & n. $\%$ & n. $\%$ & $\mathrm{n}$. \\
\hline CI & $\begin{array}{ll}57 & 15,08\end{array}$ & $92 \quad 15,73$ & $\begin{array}{ll}99 & 22,45\end{array}$ & $109 \quad 16,95$ & $23 \quad 26,74$ & $\begin{array}{ll}5 & 20,00\end{array}$ & $\begin{array}{ll}5 & 18,52\end{array}$ & 390 \\
\hline SP & 32184,92 & 49384,27 & 34277,55 & 53483,05 & $63 \quad 73,26$ & 2080,00 & 2281,48 & 1795 \\
\hline
\end{tabular}

(Santos, 2007, p. 74)

Contrariamente aos resultados obtidos na atividade formal, o teste de produção levou à maior realização do OI na forma de SP do que na forma de clítico. Assim como se observou o uso da preposição para em níveis muito superiores ao da preposição $a$ em todas as séries. Esses resultados também corroboram os achados de Gomes (1996) e Freire (2005)

Dessa forma, para Santos o OI é realizado de acordo com o nível de escolaridade, mas está mais relacionado ao grau de formalidade exigido ao aluno e pela situação discursiva. Situações formais que exigem vocabulário mais elaborado levam ao preenchimento do OI com clítico dativo lhe. Contudo, na tentativa de acertar o uso de uma variante a qual ele não domina, o aluno use também o acusativo nesta posição.

A opção entre clítico e SP, então dependerá da situação e do grau de formalidade exigidos. Se menos formal, o aluno prefere o SP na realização do OI, e como acontece com o clítico, o grau e a exigência de formalidade é o que determinará o tipo de preposição que encabeçará o SP, [+formal] $a$, [-formal] para.

(Santos, 2007, p. 90) 
Fica evidente, portanto que, como afirma Freire (2011) baseando-se em seu estudo sobre a fala dos informantes cultos, a escola fracassa nessa tentativa de resgatar as formas de prestígio. Em seu estudo, não houve um só uso da variante padrão, somente as estratégias alternativas a ela se mostraram produtivas no PB, o que o diferencia fortemente do PE, que faz largo uso do pronome dativo em referência à terceira pessoa.

\begin{abstract}
Em meio a essa diferença entre fala e escrita no Brasil, à escola caberia ensinar a norma culta oficial aos alunos, sendo socialmente cobrada no desempenho dessa função. Por conseguinte, ela teria a tarefa de recuperar (ou seria ensinar?) formas que já não fazem parte do sistema linguístico dos alunos. Sem dúvida, ensinar a norma oficial significa ensinar uma segunda língua, visto que os alunos, ao entrarem na escola, já possuem uma gramática completa, adquirida num processo natural, desde os primeiros meses de idade, a partir de dados fornecidos pelos que os cercam.
\end{abstract}

(Freire, 2011)

Neste trabalho, Freire investigou alguns livros didáticos aprovados pelo MEC na última década, tanto do ensino fundamental quanto do ensino médio, com o intuito de vislumbrar, pelo menos em parte, a prática escolar. Seu objetivo não foi traçar uma análise crítica completa a respeito do conteúdo gramatical veiculado nas obras, mas levantar alguns aspectos relativos ao tratamento dispensado aos clíticos de terceira pessoa, que suscitaram algumas reflexões sobre o ensino de Língua Portuguesa na escola. Assim, as estratégias presentes nas obras consultadas foram as "correções" baseadas na chamada norma culta e os exercícios de substituição

Tais estratégias não seriam eficientes, segundo o autor, visto que a ausência do clítico lhe na referência à terceira pessoa, como dito, foi total na amostra de língua falada. Com relação à língua escrita, Freire apoia-se nos estudos de Averbug (2000) e Freire (2005) para sustentar que é particularmente na escrita que se percebe algum resultado mais visível sobre a atuação da escola na recuperação das variantes prescritas pela tradição escolar, contudo concentrada em textos de caráter muito formal, como editoriais e resenhas.

$\mathrm{O}$ que indica que o uso dos clíticos acusativo e dativo na escrita brasileira parece ser mais um fenômeno de morfologia estilística que gramatical, segundo a observação de Kato (1996), ou seja, no português brasileiro esse uso não é comum em qualquer evento de comunicação, como no português europeu, mas somente em eventos com marca de formalidade.

(Freire, 2011) 
Diante desse quadro, o autor questiona-se como se poderia ensinar com mais eficácia o emprego dos clíticos de terceira pessoa. Sua resposta baseia-se na compreensão do professor de que o sistema linguístico brasileiro passa por processo de mudança, o que aumenta a distância que sempre existiu entre fala e escrita no Brasil. Além disso, segundo ele, a escola deve entender que a norma padrão escrita do PB não coincide necessariamente com a descrição da gramática tradicional, cujos exemplos de uso linguístico são geralmente literários e retratam uma época pretérita. Seria necessário observar em diferentes meios de comunicação que revelem a escrita padrão do português brasileiro: a norma culta veiculada pela imprensa.

Freire continua sua reflexão afirmando que o professor de Língua Portuguesa deve ter consciência de que existe uma profunda diferença entre a língua prescrita pelas gramáticas e a língua que seus alunos trazem de casa.

Portanto, se o propósito é levar ao conhecimento do aluno a língua
formal, o ensino de clíticos de terceira pessoa deveria basear-se não
em meras recomendações proibitivas ou em exercícios artificiais de
substituição, mas na percepção dos escritores brasileiros de hoje sobre
esse fato gramatical, obtida a partir da leitura de textos produzidos
pela imprensa, que remetem a situações reais e representam o que
efetivamente constitui a norma culta brasileira.

(Freire, 2011)

Assim, segundo o pesquisador, ao invés de simples análises de sentenças isoladas e descontextualizadas, caberia ao professor de Língua Portuguesa a análise de textos de imprensa e, a partir daí, fazer com que os alunos se apropriassem das normas.

Percebemos, então, que as inúmeras divergências quanto à nomenclatura e definição do OI no PB somadas a estratégias ineficientes baseadas no "certo" e "errado" no "ensino" da Língua Portuguesa têm se refletido no conhecimento e uso que o falante tem de sua própria língua.

A gramática tradicional por não contemplar o português em uso acaba ignorando situações adversas no que concerne ao OI e, consequentemente, o aluno é obrigado a aceitar classificações limitadas e equivocadas.

Acima disso, ao deparar-se com estratégias não vivenciadas em seu cotidiano, o aluno vê-se na escola como aprendiz de uma língua estrangeira. Nesse quadro, encaixa-se o "ensino" do clítico dativo de terceira pessoa. Por não fazer parte do vernáculo do falante, é utilizado somente em textos escritos mais formais e, por inúmeras vezes, em casos de hipercorreção. 


\section{A escola e os alunos}

Como visto no capítulo 1, a criança chega à sala de aula com sua gramática nuclear definida, isto é, com todos os valores dos parâmetros selecionados. Tal seleção já ocorre nas primeiras interações com os pais e com os amigos, nesse instante a criança recebe um input linguístico, o primeiro estímulo ao qual ela seria submetida.

$\mathrm{Na}$ fase escolar, ela recebe um segundo input, de diferente natureza, pois é planejado, sistematizado, com um conteúdo pré-estabelecido pelo professor. De acordo com Kato (2005), esta seria uma segunda “ G2”, ou seja, uma gramática periférica.

No entanto, muitas crianças podem chegar à escola com essa periferia já marcada, se tiverem tido acesso às formas das língua escrita, oferecida por pais ou por pessoas de sua convivência. Provavelmente esses seriam fatores responsáveis pelas diferenças existentes entre os alunos quando chegam à escola, no sentido em que terão sido expostos a um "input estilístico" na fase pré-escolar. Portanto, haveria um menor distanciamento entre a Língua-I, composta pela gramática nuclear e periferia e o letramento. Por outro lado, aqueles que não recebem qualquer estímulo em casa enfrentam a "aquisição" do letramento com maior dificuldade, devido ao enorme abismo existente entre fala e escrita no PB.

Outro fator agravante nesse distanciamento é que a escola assume como sua primordial função o ensino da norma culta oficial, objetivando levar os alunos ao domínio das variedades de prestígios. Sob esse ponto de vista, ela teria a tarefa de recuperar formas que podem ainda não fazer parte do sistema linguístico dos falantes. No entanto, como constatado no capítulo 1, muitos trabalhos já apontaram para o insucesso escolar nesse ofício e, no caso específico do uso dos clíticos de terceira pessoa, por exemplo, as estratégias empregadas na tentativa de recuperá-los não têm tido os resultados esperados.

Um grande problema é que do ponto de vista científico, o PB vive uma fase de diglossia, em que praticamos uma modalidade linguística no ambiente familiar e outra distinta nos ambientes acadêmicos, fato este ignorado nas aulas de Língua Portuguesa.

Com o intuito de verificar qual o papel da escola e do ambiente social da criança nessas mudanças apontadas no capítulo 2, iremos neste capítulo refletir sobre as diretrizes apontadas pelos Parâmetros Curriculares Nacionais no que se refere ao ensino do Português na sala de aula e caracterizar as escolas que forneceram as redações utilizadas nesta dissertação. Para isso, esse capítulo será dividido em três seções.

$\mathrm{Na}$ primeira, verificaremos se as diretrizes nacionais que permeiam o ensino do português nas escolas consideram as variações do PB nessa tarefa de "ensino" da língua. Para 
isso, buscamos nos Parâmetros Curriculares Nacionais as normativas referentes ao ensino do português na sala de aula no que concerne os diferentes falares brasileiros e o vernáculo internalizado de cada aluno.

Na seção seguinte, elaboremos um perfil das duas escolas utilizadas neste trabalho, a saber, o Liceu Santista, escola particular e a Unidade Municipal de Educação (UME) Edméa Ladevig. Nosso intuito é apontar as diferenças existentes em cada uma das escolas e, dessa forma, verificar se essas distinções serão refletidas na análise dos dados (capítulo 4)

\title{
3.1. Os Parâmetros Curriculares Nacionais
}

Como foi discutido no capítulo 2, Freire (2011) argumenta que o ensino não deveria pautar-se em proibições ou em exercícios artificiais descontextualizados, mas na leitura atenta das obras dos escritores brasileiros e de textos produzidos pela imprensa, que representam o que efetivamente constitui a norma culta brasileira.

Nesta seção vamos mostrar que, na verdade, essa já é uma preocupação assinalada pelos Parâmetros Curriculares Nacionais, como se depreende do texto abaixo:

\begin{abstract}
...não se justifica tratar o ensino gramatical desarticulado das práticas de linguagem. É o caso, por exemplo, da gramática que, ensinada de forma descontextualizada, tornou-se emblemática de um conteúdo estritamente escolar, do tipo que só serve para ir bem na prova e passar de ano - uma prática pedagógica que vai da metalíngua para a língua por meio de exemplificação, exercícios de reconhecimento e memorização de terminologia.

Em função disso, dicute-se se há ou não necessidade de ensinar gramática. Mas essa é uma falsa questão: a questão verdadeira é o que, para que e como ensiná-la.
\end{abstract}

(PCN, 1997, p. 28)

No entanto, a julgar pelos livros didáticos ${ }^{26}$, percebe-se que estes ainda não têm estas determinações.

É importante ressaltar, contudo, que esses Parâmetros, publicados em 1997, não têm caráter normativo e servem como auxílio na elaboração do Projeto Pedagógico das escolas.

Especificamente o PCN que discute o ensino da Língua Portuguesa pauta-se por rever as práticas de ensino da língua, na direção de orientá-las para a valorização do conhecimento

\footnotetext{
${ }^{26}$ A análise de livros didáticos não faz parte da pesquisa dessa dissertação. No entanto, a prática pessoal de sala de aula evidencia que esse material, cerne do trabalho do professor, não apresenta a língua em uso, mas ocorrências artificias da linguagem.
} 
prévio que o aluno traz para a sala de aula. Em substituição ao estruturalismo e teoria da comunicação, o PCN aponta para a concepção da linguagem como forma de interação fundamental nas relações sociais e para a percepção das diferenças dialetais.

\begin{abstract}
Assim, um projeto educativo comprometido com a democratização social e cultural atribui à escola a função e a responsabilidade de contribuir para garantir a todos os alunos o acesso aos saberes linguísticos necessários para o exercício da cidadania.

Essa responsabilidade é tanto maior quanto menor for o grau de letramento das comunidades em que vivem os alunos. Considerando os diferentes níveis de conhecimento prévio, cabe à escola promover sua ampliação de forma que, progressivamente, durante os oito anos do ensino fundamental, cada aluno se torne capaz de interpretar diferentes textos que circulam socialmente, de assumir a palavra e, como cidadão, de produzir textos eficazes nas mais variadas situações.
\end{abstract}

(PCN, 1997, p. 19)

Essa diferença apontada pelo PCN entre as crianças que chegam à escola, também foi objeto de estudo desta dissertação. Com o objetivo de aferir se há contraste entre a gramática internalizada pela criança da escola pública e particular, fez-se necessário buscar o corpus em duas diferentes escolas, sendo uma pública e uma privada. Adiante, faremos um breve perfil das instituições que forneceram as redações base do corpus estudado.

\title{
3.2 As escolas
}

Para o levantamento do corpus, foram selecionadas duas escolas na Baixada Santista, sendo uma particular e uma pública. Escolhemos aleatoriamente o Liceu Santista, escola particular, e o UME Edméa Ladevig, escola pública.

Nosso objetivo em escolher duas escolas distintas, uma pública e uma privada, partiu da hipótese de que a clientela que as frequenta, seria igualmente diferente em termos socioeconômicos, ou seja, em uma delas, mais elitista, as crianças teriam uma conhecimento linguístico interiorizado mais rico e variável. Neste caso, poderiam recuperar com maior êxito as formas gramaticais preconizadas pela escola. À segunda receberia uma clientela mais limitada no sentido da exposição a uma experiência linguística mais rica e variada e, portanto, encontraria mais dificuldade no sentido de uma menor assimilação e produtividade das formas de prestígio. 
Assim, um breve perfil das escolas será aqui desenhado, com o objetivo de obter uma visão comparativa entre elas, tanto no que se refere à dinâmica pedagógica que desenvolvem quanto no que se refere aos aspectos ambientais e sociais com os quais estão envolvidas.

Primeiro, no entanto, é importante destacar alguma informações da cidade de Santos, cidade em que ambas as escolas estão inseridas. De acordo com o censo 2006, Santos tem 419.757 habitantes e uma área de $280,2 \mathrm{~km}^{2}$. Logo, se comparada à capital (SP), a cidade é pequena e, por este motivo, não há discrepâncias geográficas entre as escolas. Aliás, na observação do mapa abaixo, verificamos que ambas são bem próximas, distando $1,7 \mathrm{~km}$ uma da outra.

Figura 01 - Mapa - distância entre as escolas selecionadas.

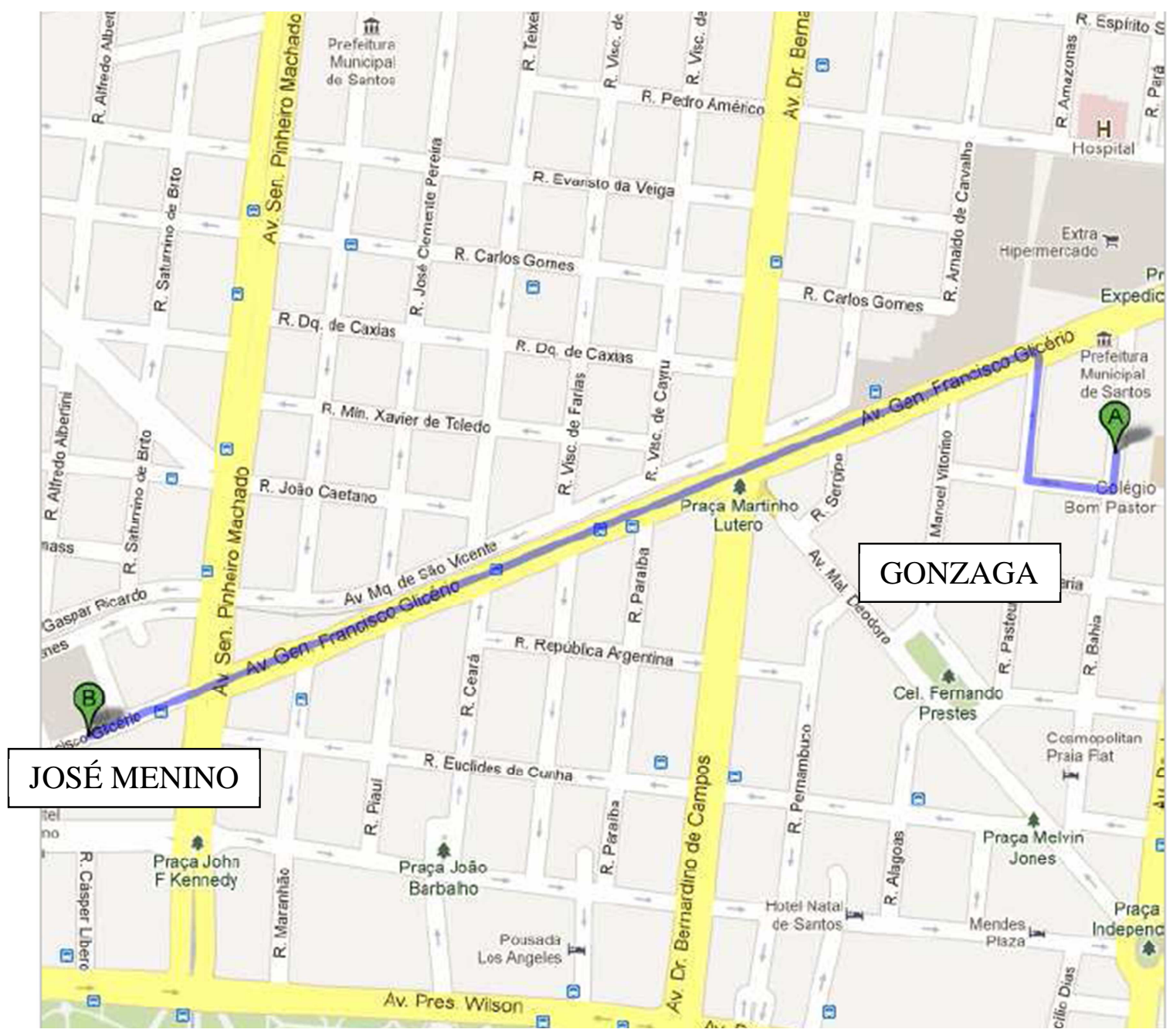

(Google Maps)

A escola pública situa-se no bairro do Gonzaga - ponto A no mapa - e a particular no José Menino - ponto B. Os dois bairros são muito próximos, separados apenas pelo bairro da 
Pompéia. O Gonzaga fica delimitado pela orla da praia, a Avenida Dr. Bernardino de Campos, Avenida Washington Luiz e pela Avenida Francisco Glicério. Já o limite do bairro José Menino são os bairros da Pompéia, Marapé, Morros e a cidade de São Vicente.

Essa proximidade faz com que haja certas similaridades entre essas regiões. Ambas englobam a orla da praia, área nobre de Santos que passa por profundas transformações advindas da expansão imobiliária, pela qual passa a cidade, reflexo das recentes descobertas das bacias do pré-sal que abalaram a economia municipal, principalmente na questão imobiliária e portuária.

Inúmeros condomínios de alto padrão estão em construção ao longo da avenida da praia, modificando não só a economia, mas a geografia da região. O gráfico abaixo aponta esse aumento do PIB na cidade.

Gráfico 10 - Aumento do PIB - per capita (R\$) na cidade de Santos

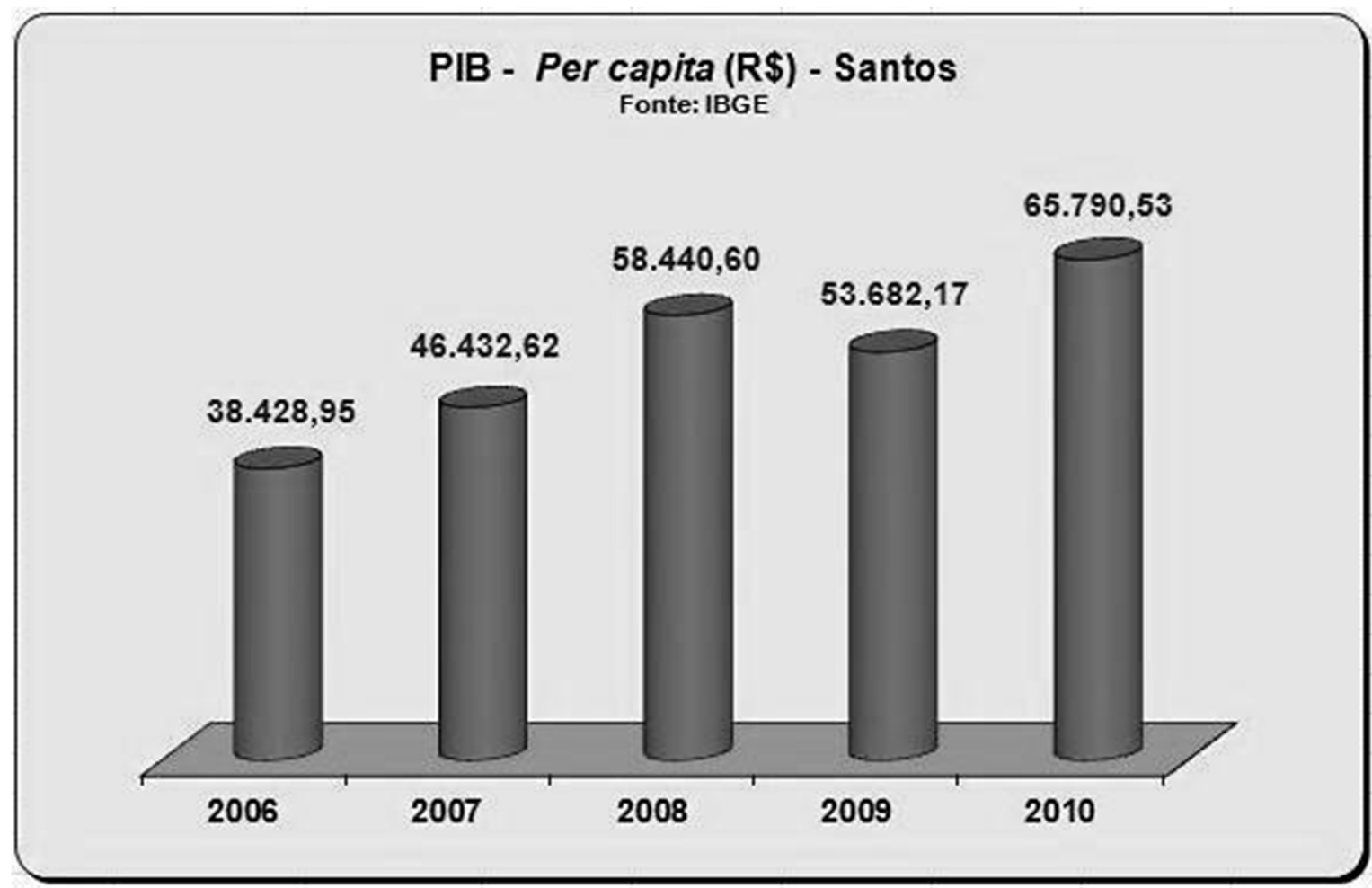

(Investsantos)

O bairro do José Menino tem 8.652 habitantes (censo 2010) e uma área de $0,55 \mathrm{~km}^{2}$ no solo $^{27}$. O Gonzaga tem 24.788 habitantes e uma área de $10,41 \mathrm{~km}^{2}$. Apesar dessa diferença em tamanho, os bairros apresentam características similares.

\footnotetext{
${ }^{27}$ O bairro contempla uma região de morros não analisada devido a sua singularidade.
} 
Com relação aos aspectos educacionais, a cidade apresenta taxa de analfabetismo, segundo o IBGE, de 2,20\% da população acima de 15 anos. O Gonzaga possui seis instituições de ensino, sendo três particulares e três públicas. Já o José Menino, duas particulares e duas públicas, sendo estas últimas situadas no morro.

Entre essas escolas, encontramos as que forneceram o material utilizado nesta pesquisa. Nas seções seguintes, faremos uma breve apresentação destas instituições de ensino.

\subsubsection{Identidade da Escola Particular - Liceu Santista}

O Liceu Santista tem 111 anos e é considerada uma escola tradicional e conceituada na cidade. Como dissemos, localiza-se no bairro do José Menino, o qual se caracteriza por sua proximidade à praia, à cidade de São Vicente e à entrada da cidade, sendo, portanto, escolhido por muitos moradores que trabalham em São Paulo.

Em ranking fornecido pelo Ministério da Educação, a escola figura entre as dez melhores notas no Exame Nacional do Ensino Médio, avaliação desenvolvida pelo MEC que visa não só à aferição da qualidade de ensino como o ingresso às universidades. Tal nota coloca a escola entre as melhores da cidade.

Não obstante exista uma proximidade geográfica em relação à UME Edméa Ladevig, o corpo discente de ambas as instituições de ensino é bastante díspar. A mensalidade do colégio particular é uma das mais caras da região, logo, os alunos que lá estudam fazem parte de uma elite social e, por que não, linguística. Imagina-se, pois, que o ambiente familiar desses alunos ofereça um input linguístico alicerçado nas formas de prestígio características dessa camada que obteve maior tempo de estudo em detrimento daqueles que não o tiveram.

Além disso, não há problema de falta ou ausência de educadores, logo o aluno não sofre com lacunas no ensino durante o ano letivo. Outro dado importante refere-se ao salário base, a hora/aula de um professor desta escola particular é aproximadamente $110 \%$ maior do que de um professor da escola pública municipal. O que faz com que muitos profissionais acabem abandonando o ensino público e optem por lecionar somente na rede privada, como noticiado cotidianamente pelas mídias.

De acordo com o Plano Escolar, a instituição tem como objetivo "a garantia das condições que favoreçam o desenvolvimento das crianças e jovens de forma harmoniosa, dentro da filosofia cristã e da religião católica, por meio dos valores da ética, da liberdade, da cooperação, da solidariedade e do respeito contribuindo para a integração e convivência na 
sociedade" (Plano, 2011, p.18). O texto afirma, ainda, que a escola valoriza o conhecimento como construção individual dos alunos, ou seja, à escola caberia o reconhecimento das individualidades já trazidas pelos alunos ao ambiente acadêmico, e o respeito a essas particularidades que imaginamos possam ser, inclusive, linguísticas.

No início do ano letivo, o professor elabora seu plano de ensino que tem como meta o planejamento dos objetivos, metodologia, programa curricular, procedimentos e avaliação do ano escolar. Observa-se, pois, uma autonomia e responsabilidade do educador na forma de gerir sua prática em sala de aula e, consequentemente, no trabalho do "ensino da língua".

\subsubsection{Identidade da Escola Pública - UME Edméa Ladevig}

A Unidade Municipal de Ensino Edméa Ladevig tem 22 anos e, segundo o próprio Projeto Político Pedagógico (PPP) da escola, está situada em um bairro bem localizado, o Gonzaga, que, como mencionado acima, é de fácil acesso e permeado por diversidades culturais. Tal região caracteriza-se pelo comércio abundante, apesar de ainda manter uma complexa área residencial.

Sendo esta uma escola urbana e localizada em uma área central da cidade, podemos supor que os alunos tem acesso à linguagem considerada de maior prestígio, em contraposição aos dialetos das áreas rurais e periféricas.

No texto do projeto há ainda referências à diversidade social dos alunos. Tal fato, provavelmente, deve ser consequência do aumento no número de estudantes que migram da escola particular em busca do ensino gratuito. Diante da pluralidade de camadas sociais, o PPP afirma que à escola caberia "promover e facilitar as adaptações necessárias para que não existam interferências no relacionamento social, nem na aprendizagem causada pela discrepância sócio financeira da clientela escolar." (Projeto, 2011, p. 21).

Ainda de acordo com o Projeto Político Pedagógico, os professores da instituição seriam "em boa parte comprometidos, dedicados e preocupados [...] Os mesmos preconizariam, em suas aulas, a pluralidade cultural, a inclusão, o respeito, a cidadania e o futuro prosseguimento nos estudos com vistas à inserção no mercado de trabalho. Segundo mesmo texto, apesar receberem uma má remuneração, isto não seria empecilho para um trabalho voltado ao desenvolvimento das competências e habilidades, "levando sempre em conta as inclusões, tanto sociais como patológicas". (Projeto, 2011, p. 23) Outro fator apontado no projeto é a desestrutura familiar e a falta de participação dos responsáveis na vida 
escolar do jovem. "Infelizmente, muitos pais desta unidade municipal de ensino (U.M.E.) ainda se mantém afastados do conselho de escola (C.E.), talvez por temer assumir responsabilidades de que não possam dar conta." (Projeto, 2011, p.23).

A falta de professores também seria um enfraquecedor dos elos entre a comunidade escolar e um obstáculo para os alunos atingirem os objetivos acadêmicos propostos pela instituição.

Apesar desse quadro, a escola foi uma das que obtiveram melhores resultados na região no Ideb 2811 (Índice de Desenvolvimento da Educação Básica), divulgado pelo MEC (Ministério da Educação). A unidade de ensino atingiu 5,0 no indicador, ou seja, 0,9 a mais do que a média nacional e 1,1 mais alto do que a meta para 2011, de 3,9.

Outro importante dado é a nota da escola em Língua Portuguesa na Prova Brasil, avaliação aplicada a todos os alunos da rede pública do $5^{\circ}$ e $9^{\circ}$ ano. A escola atingiu 270 pontos, enquadrando-se no nível 6 de desempenho em leitura. Esse nível varia de 0 a 9 e engloba as competências atingidas pelos alunos de acordo com a nota obtida.

Diante do quadro caótico que se desenha para o ensino público brasileiro, o que se observa especialmente nessa unidade pública de ensino é uma situação privilegiada em que ainda se preserva o foco no ensino-aprendizagem e certa posição de destaque nas principais avaliações externas aplicadas pelo governo federal. Por outro lado, seria necessário refletir sobre o nível exigido nessas provas, confrontando-o com os índices obtidos pelas escolas particulares, tal análise seria por demais minuciosa e não sendo pertinente aos estudos dessa dissertação.

\subsection{Comparação entre as identidades assumidas pelas escolas}

Na leitura dos documentos da escola, o que se observa é um grande contraste no modo com ambas se apresentam. Enquanto o projeto pedagógico da escola pública é escrito como um desabafo sobre a situação do ensino, o plano escolar do colégio particular ressalta as qualidades da instituição e preocupa-se com a elaboração de uma redação de cunho mais pedagógico. Ou seja, a escola pública pareceu a nós justificar os problemas educacionais enquanto a particular ressalta apenas seus pontos positivos.

\footnotetext{
${ }^{28}$ O Índice de Desenvolvimento da Educação Básica (Ideb) foi criado pelo Inep em 2007 e tem por objetivo aferir a qualidade da educação. O indicador é calculado a partir dos dados sobre aprovação escolar, obtidos no Censo Escolar, e médias de desempenho nas avaliações do Inep, o Saeb - para as unidades da federação e para o país, e a Prova Brasil - para os municípios.
} 
Nas seções seguintes abordaremos alguns pontos importantes levantados em ambos os documentos e em dados colhidos de avaliações externas.

\subsubsection{Componentes curriculares}

Segundo o $\operatorname{artigo~} 32^{\circ}$ da LDB, Lei de Diretrizes e Bases da Educação ${ }^{29}$, que define e regulariza o sistema de educação brasileiro, o objetivo do Ensino Fundamental é a formação básica do cidadão e, para isso, é necessário "o desenvolvimento da capacidade de aprender, tendo como meios básicos o pleno domínio da leitura, da escrita e do cálculo”. (Inciso I, art. $32, \mathrm{LDB})$

Para que se atinjam essas metas, há no sistema de ensino brasileiro um currículo comum a todas as escolas do território nacional, explicitado na lei $\mathrm{n}^{\circ}$ 9.394, de 20 de dezembro de 1996. No texto, o Ensino Fundamental e Médio tem uma base comum que contempla "o estudo da língua portuguesa e da matemática, o conhecimento do mundo físico e natural e da realidade social e política, especialmente do Brasil." (Parágrafo $1^{\circ}$, art. 26, LDB). Além disso, a lei versa sobre o ensino da arte, da educação física e faz uma ressalva sobre História do Brasil. Contudo, também dispõe que ao estabelecimento escolar cabe oferecer uma parte diversificada no currículo que atenda as características regionais e locais da sociedade, da cultura, da economia e da clientela.

Especificamente, a LDB define como currículo básico para as áreas de conhecimento comum:

\section{Língua Portuguesa;}

2. Língua Materna (para populações indígenas e migrantes);

3. Matemática;

4. Ciências;

5. Geografia;

6. História;

7. Língua Estrangeira;

8. Educação Artística;

9. Educação Física;

\footnotetext{
${ }^{29}$ As Diretrizes Curriculares Nacionais são o conjunto de definições doutrinárias sobre princípios, fundamentos e procedimentos na Educação Básica, expressas pela Câmara de Educação Básica do Conselho Nacional de Educação, que orientam as escolas brasileiras dos sistemas de ensino, na organização, na articulação, no desenvolvimento e na avaliação de suas propostas pedagógicas.
} 
10. Educação Religiosa ${ }^{30}$ (na forma do art. 33 da LDB).

Diante disso, não surpreende que o currículo da escola particular e pública seja bastante similar, como aponta a tabela abaixo e que a carga horária de ambas também seja a mesma: 30horas/aula X 40 semanas (em um mês) $=1200$ horas/anuais

Tabela 12 - Componentes curriculares da Escola Pública e Particular

\begin{tabular}{|l|c|c|}
\hline \multicolumn{1}{|c|}{ Componente curricular } & $\begin{array}{c}\mathbf{6}^{\mathbf{0}} \text { ao 9 } \\
\text { Escola Pública }\end{array}$ & $\begin{array}{c}\mathbf{6}^{\mathbf{0}} \mathbf{a o} \mathbf{9}^{\mathbf{0}} \text { ano } \\
\text { Escola Particular }\end{array}$ \\
\hline Língua Portuguesa & 6 & 5 \\
\hline Matemática & 6 & 3 \\
\hline Ciências & 3 & 3 \\
\hline Geografia & 3 & 3 \\
\hline História & 3 & 2 \\
\hline Arte & 2 & 5 \\
\hline Educação Física* & 2 & 2 \\
\hline Língua Estrangeira Moderna & 1 & 1 \\
\hline Informática** & 1 & 30 \\
\hline Ensino Religioso & 30 & 1 \\
\hline Horas/aula & 3 & 5 \\
\hline
\end{tabular}

* Na escola particular há duas disciplinas distintas: Educação Física e Natação, cada uma delas com uma aula semanal.

** A disciplina Informática é denominada Informática Educativa na escola pública e Robótica na particular. É importante ressaltar que o conteúdo de Robótica engloba outras especificidades além do conhecimento tecnológico, como a arquitetura dos robôs e o trabalho em equipe.

Ressalta-se que a escola particular tem uma aula a menos de Língua Portuguesa do que a escola pública. Seria tal fato significativo na de recuperação das formas gramaticais de prestígio? Iremos oferecer uma resposta a esta questão, no capítulo 4, quando apresentaremos os resultados obtido em nosso corpus.

Uma resposta indireta, porém, pode ser agora oferecida, se tomarmos como base os índices de Promoção e Retenção das escolas analisadas.

\footnotetext{
${ }^{30}$ A Educação Religiosa, nos termos da Lei, é uma disciplina obrigatória de matrícula facultativa no sistema público (art. 33 da LDB).
} 


\subsubsection{Avaliação dos índices de Promoção e Retenção - ano base 2010}

Os índices de retenção por série disponíveis apontam uma enorme discrepância entre o ensino público e o privado. Observam-se pelos dados que a escola pública reprova muito mais alunos do que o colégio particular. Tal fato levanta duas hipóteses: (i) há diferentes parâmetros estabelecidos pelas escolas no que se refere à reprovação do aluno, sendo a particular mais condescendente do que a pública, (ii) os alunos da escola particular têm acesso a uma melhor qualidade de ensino e, portanto, aprendem efetivamente o conteúdo resultando em um desempenho que os leva a aprovação. Vejamos as tabelas (17) (18):

Tabela 13 - Escola Pública - Dados de 2010

\begin{tabular}{|c|c|c|c|}
\hline Curso/Ano & Matrícula final & Promovidos & Retidos \\
\hline $6^{\mathbf{0}}$ ano & 97 & 81 & 16 \\
\hline $7^{\mathbf{0}}$ ano & 111 & 92 & 19 \\
\hline $8^{\mathbf{o}}$ ano & 117 & 107 & 10 \\
\hline $9^{\mathbf{0}}$ ano & 79 & 79 & 0 \\
\hline
\end{tabular}

Tabela 14 - Escola Particular - Dados de 2010

\begin{tabular}{|l|c|c|c|}
\hline Curso/Ano & Matrícula final & Promovidos & Retidos \\
\hline $6^{\mathbf{0}}$ ano & 92 & 89 & 3 \\
\hline $7^{\mathbf{0}}$ ano & 81 & 76 & 0 \\
\hline $8^{\mathbf{o}}$ ano & 99 & 99 & 1 \\
\hline $9^{\circ}$ ano & 72 & 71 & 5 \\
\hline
\end{tabular}

Graficamente, essa distinção fica mais evidente, como mostrado abaixo. Há um acentuado decréscimo do número de retenções na escola pública, enquanto os índices da escola particular mantém certo equilíbrio. 
Gráfico 11 - Retenção de alunos na escola pública e particular em porcentagem.

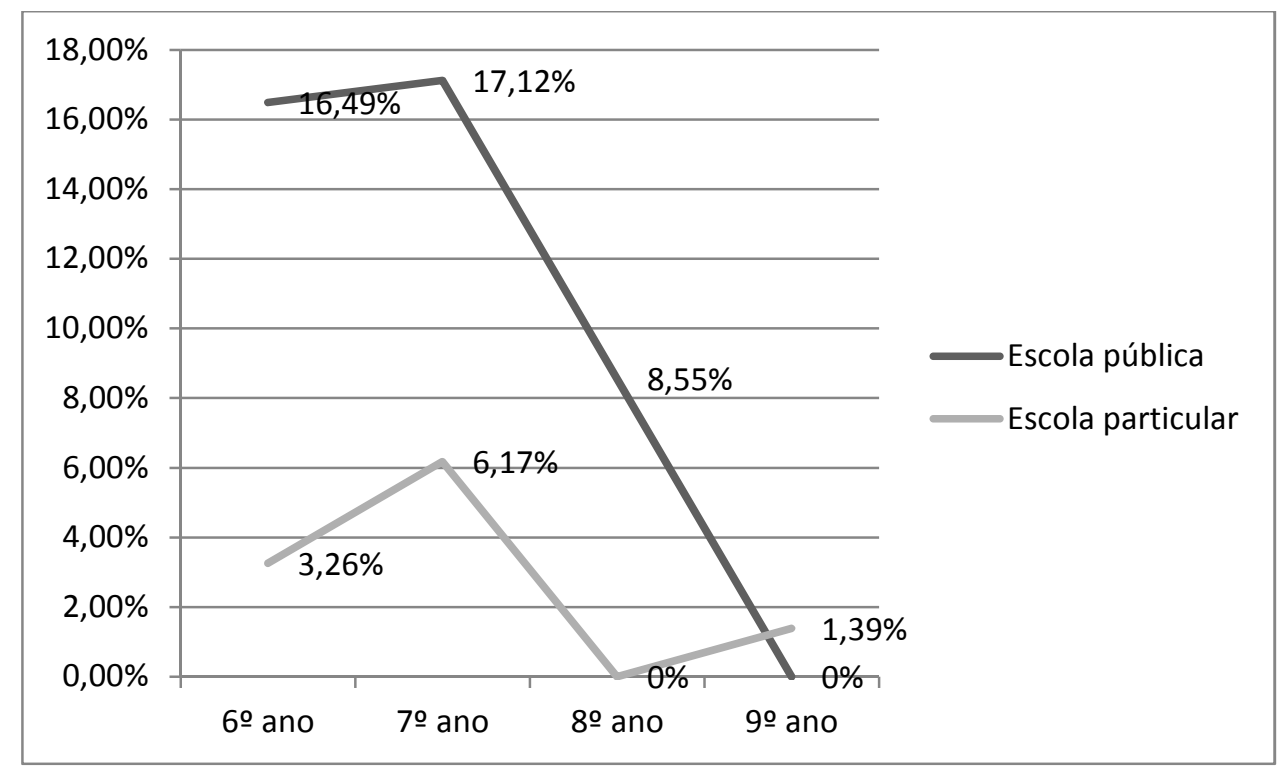

Em contrapartida não podemos deixar de observar o paradoxo gerado pelos números apresentados. É consensual a afirmação, veiculada na mídia e nos órgãos educacionais e governamentais, de que o ensino fundamental público, quando comparado ao privado , apresenta um nível inferior de conteúdo e exigência. De fato, representa um lugar comum a afirmação de que a aprovação ou promoção para as séries superiores, nestes estabelecimentos de ensino, é um processo menos problemático e mais acessível a um número maior de estudantes. Contudo, os números que obtivemos não refletiram esse discurso e o que se vê é um índice de reprovação muito superior na instituição pública. Neste caso, cabe uma análise social e minuciosa das especificidades que norteiam cada escola, estudo esse extremamente amplo e complexo, sobre o qual não faremos nem mesmo uma abordagem superficial, sob o risco de distorcermos os dados.

Não obstante, para um enfoque mais aprofundado nesta pesquisa, achamos que seria interessante observar a taxa de retenção dos alunos especificamente em Língua Portuguesa.

Para nossa surpresa, os índices apresentam fortes discrepâncias, pois não há nenhuma classe da escola particular com taxa de retenção superior a $20 \%$ nesta disciplina, sendo o índice mais alto de $6,17 \%$ no $7^{\circ}$ ano. Por outro lado, três classes da escola pública obtiveram esse valor crítico no número de reprovados, sendo todas elas no período da tarde. 
Tabela 15 - Taxa de retenção crítica (> 20\%) por ano em Língua Portuguesa da Escola Pública*

\begin{tabular}{|l|l|l|l|}
\hline \multicolumn{1}{|c|}{ Ano } & \multicolumn{1}{c|}{ Classe } & \multicolumn{1}{c|}{ Período } & \multicolumn{1}{c|}{ Taxa de retenção } \\
\hline $6^{\mathbf{0}}$ ano & B & Tarde & $33,33 \%$ \\
\hline $7^{\mathbf{0}}$ ano & C & Tarde & $28,57 \%$ \\
\hline $7^{\mathbf{0}}$ ano & D & Tarde & $25,0 \%$ \\
\hline
\end{tabular}

*Não há tabela comparativa com dados da escola particular, pois nenhuma classe apresentou índices superiores a $20 \%$

Observa-se, portanto, um alto grau de dificuldade que o aluno encontra no aprendizado dessa L2, a ponto de não assimilar o conteúdo discorrido em sala de aula, e ter que refazer um ano de aprendizado. Se pensarmos que há, em média, 30 alunos em uma sala de aula, temos quase 10 estudantes que não aprenderam o conteúdo mínimo de Língua Portuguesa exigido para a continuidade dos estudos. Ou seja, para 10 alunos, esta língua ensinada em sala de aula é totalmente distante, é efetivamente uma língua estrangeira.

Esse alto índice de repetência tem consequências a cada ano escolar e o resultado são alunos com idade muito superior ao indicado para a série. Por não se sentirem parte do grupo, os alunos ficam ainda mais desmotivados e tendem ao insucesso, alimentando essa reação em cadeia. Conforme dados da tabela 20, observamos que há um número mais elevado de alunos com idade superior à normalmente esperada no oitavo do colégio público $(21,67 \%)$. Destacam-se, ainda, três alunos com 15 anos no $6^{\circ}$ ano e oito alunos com 16 anos no $8^{\circ}$ ano. Tal situação não se aplica ao ensino privado, onde não encontramos nenhum caso de distorção de idade superior a um ano.

Não podemos deixar de mencionar que dificilmente um aluno que reprova o ano em uma escola particular permanece nesta escola, visto que por questões econômicas os responsáveis optam por transferir o jovem para o ensino gratuito. 
Tabela 16 - Relatório de Distorção de Idade $\left(6^{\circ}\right.$ ao $9^{\circ}$ ano $)$ na escola pública - ano de referência 2010

\begin{tabular}{|l|l|l|l|l|l|l|l|c|l|}
\hline Ano & $\begin{array}{c}\text { Matrícula } \\
\text { Final }\end{array}$ & $\begin{array}{c}\text { Até 12 } \\
\text { anos }\end{array}$ & $\begin{array}{c}\text { Até 13 } \\
\text { anos }\end{array}$ & $\begin{array}{c}\text { Até 14 } \\
\text { anos }\end{array}$ & $\begin{array}{c}\text { Até 15 } \\
\text { anos }\end{array}$ & $\begin{array}{c}\text { Até 16 } \\
\text { anos }\end{array}$ & $\begin{array}{c}\text { Acima } \\
\text { de 16 } \\
\text { anos }\end{array}$ & $\begin{array}{c}\text { Alunos } \\
\text { com idade } \\
\text { superior ao } \\
\text { ano }\end{array}$ & $\begin{array}{c}\text { Taxa de } \\
\text { distorção } \\
(\%)\end{array}$ \\
\hline $6^{\mathbf{0}}$ ano & 99 & 42 & 8 & 1 & 3 & 0 & 0 & 12 & 12,12 \\
\hline $7^{\mathbf{0}}$ ano & 115 & 62 & 36 & 9 & 5 & 1 & 2 & 17 & 14,78 \\
\hline $8^{\mathbf{o}}$ ano & 120 & 0 & 66 & 28 & 15 & 8 & 3 & 26 & 21,67 \\
\hline $9^{\mathbf{0}}$ ano & 79 & 0 & 1 & 48 & 19 & 7 & 4 & 11 & 13,92 \\
\hline
\end{tabular}

\subsubsection{Perfil socioeconômico dos alunos}

Com intuito de verificar se os alunos da escola pública e particular incluíam-se em cenários sociais distintos, capazes de influenciar no vernáculo já internalizado nos primeiros anos de contato com a língua, e nas formas gramaticais apreendidas formalmente na escola, buscamos, em dois sistemas de avaliação, o perfil socioeconômico dos alunos das escolas estudadas.

No Liceu Santista, consultamos o AVALIA e na UME Edméa Ladevig, a Prova Brasil e o Saeb.

É importante ressaltar que, como ambas as avaliações são feitas nas séries finais de cada ciclo (ensino fundamental 1, ensino fundamental 2 e ensino médio), focamos apenas os resultados obtidos pelos alunos do $9^{\circ}$ ano, série final do período investigado nessa dissertação.

Sabemos, no entanto, que como não centramos nossa análise em conhecimento cognitivo, mas em percepção social, os dados dos alunos do $9^{\circ}$ ano refletem o perfil dos estudantes como um todo, servindo como amostragem válida para a análise que se pretende efetivar.

O AVALIA - Assessoria Educacional é uma empresa nacional no mercado de avaliação de escolas e sistemas de ensino de instituições públicas e privadas. É uma empresa particular, logo, cabe às instituições de ensino contratarem seus serviços. O Liceu Santista realiza essa avaliação por pertencer a ANEC (Associação Nacional de Educação Católica), órgão que paga essa avaliação nas escolas católicas. As avaliações englobam não só a aferição de conhecimento do aluno em disciplinas específicas, principalmente em Língua Portuguesa e Matemática; como, por meio de diferentes questionários, evidenciam o perfil econômico e social dos alunos. 
Já a Prova Brasil é aplicada a cada dois anos em estudantes do $5^{\circ}$ e do $9^{\circ}$ ano do Ensino Fundamental de escolas da rede pública. É por meio dos testes de Língua Portuguesa e de Matemática que o país monitora os índices de qualidade da Educação. Essa avaliação também engloba um questionário socioeconômico. Foram esses questionários que forneceram as informações sobre o perfil dos alunos que forneceram as redações utilizadas como corpus deste estudo.

Em 2011, 81 alunos do $9^{\circ}$ ano do Liceu Santista e 80 alunos da UME Edméa Ladevig, responderam ao questionário do AVALIA e da Prova Brasil, respectivamente. Uma das questões aferia a escolaridade dos pais e mães dos alunos. O resultado evidencia a diferença no tempo de permanência na escola desses responsáveis, verificados na tabela abaixo:

Tabela 17 - Escolaridade dos pais dos alunos de $9^{\circ}$ ano da UME Edméa Ladevig

\begin{tabular}{|l|c|c|}
\hline & Pai & Mãe \\
\hline Completou somente até o 5 ${ }^{\circ}$ ano & $8 \%$ & $15 \%$ \\
\hline Completou o E.M. ${ }^{31}$, mas não completou a faculdade & $41 \%$ & $35 \%$ \\
\hline Completou a faculdade & $11 \%$ & $14 \%$ \\
\hline Sabem ler & $95 \%$ & $99 \%$ \\
\hline
\end{tabular}

(Ideb, 2011)

Tabela 18 - Escolaridade dos pais dos alunos de $9^{\circ}$ ano do Liceu Santista

\begin{tabular}{|l|c|c|}
\hline & Pai & Mãe \\
\hline Completou somente até o 5 ${ }^{\circ}$ ano & $3 \%$ & $2 \%$ \\
\hline Completou o E.M., mas não completou a faculdade & $16 \%$ & $15 \%$ \\
\hline Completou a faculdade & $71 \%$ & $76 \%$ \\
\hline
\end{tabular}

(AVALIA, 2011)

Nessa comparação entre a escolaridade, comprova-se que os alunos do Liceu Santista tem em casa um ambiente em que, a princípio, poderiam se manifestar as formas de prestígio, já que os pais usufruíram maior tempo de ensino formal na escola e na universidade.

Os questionários também apontam que $46 \%$ dos alunos do $9^{\circ}$ ano da escola pública nunca frequentaram a biblioteca da escola e $28 \%$ tem hábito de ler livros em geral, enquanto

\footnotetext{
${ }^{31}$ E.M. = Ensino Médio
} 
$44 \%^{32}$ dos alunos do $9^{\circ}$ ano da escola particular afirmaram ser a leitura um dos divertimentos favoritos.

Se há essa disparidade entre o grau de escolaridade dos responsáveis por esses jovens e o hábito de leitura que cultivam, resta-nos verificar se tal fato ira refletir nos dados selecionados no corpus.

$\mathrm{Na}$ análise entre as duas escolas, o que se observa a primeira vista é certa regularidade entre elas, proporcionada principalmente pela proximidade geográfica. No entanto, embora as escolas estejam ambas localizadas em bairros centrais e a escola pública não ser uma escola de periferia, há um fator importante responsável que nos faz considerar seus diferentes públicos: o poder aquisitivo. Enquanto a escola pública é gratuita, o Liceu Santista cobra uma mensalidade de $\mathrm{R} \$ 1.235,00$, no Ensino Fundamental.

Verificamos como esse fator econômico se reflete no ambiente social familiar, pela enorme diferença de universitários entre os responsáveis por esses alunos.

Logo, a escolha por estas duas instituições foi pautada em um critério social de poder aquisitivo, afinal, este fato implica em que, teoricamente, a criança que vive em um ambiente de alto poder financeiro teria uma vivência maior com a linguagem, seja no acesso a livros, a viagens e no próprio ambiente familiar.

\footnotetext{
32 A questão respondida era, na verdade, uma afirmação: A leitura é um dos meus divertimentos favoritos, os alunos deviam responder entre uma escala de 1 a 4 se concordavam com essa afirmação, sendo 1 o menor grau de concordância e 4 o maior grau de concordância. $23 \%$ dos alunos responderam 3 e 21\%, 4; somando-se, obtemos os $44 \%$ considerados leitores.
} 


\section{Análise descritiva dos dados}

Como mencionado na introdução, o objetivo desta pesquisa é verificar a implementação das três estratégias de preenchimento do OI em contextos dos verbos bitransitivo já comprovadas pelos trabalhos acadêmicos, a saber: (i) substituição da preposição a por para, (ii) perda progressiva dos clíticos de $3^{\mathrm{a}}$ pessoa (lhe/lhes), substituídos pelas formas preposicionadas (a/para ele/eles, a/para ela/elas) e (iii) aumento das formas pronominais nulas fonologicamente, em textos de alunos do Ensino Fundamental 2 (EF2).

A análise descritiva dos dados será apresentada neste capítulo, dividido em quatro seções. Na primeira, apresentamos a metodologia seguida neste estudo e o corpus por nós utilizado, o qual se baseou em produções textuais selecionadas aleatoriamente em dois colégios da cidade de Santos, o Liceu Santista, escola particular e a UME Edméa Ladevig, escola pública. Foram coletadas 80 composições, ao longo do ano de 2010.

Sabendo que no EF2 os tipos ${ }^{33}$ de textos mais solicitados são narração e dissertação, a narração pareceu-nos mais adequada para o estudo das formas em variação, visto que, apesar de ser um texto escrito apresenta marcas de oralidade. (conf. Luzio e Rodrigues, 2009)

Na seção dois, apresentamos uma análise descritiva, dividida por estratégia, por série e por escola, dos resultados gerais das realizações do OI anafórico de $3^{\mathrm{a}}$ pessoa identificadas nos textos. Nas subseções seguintes, examinamos qual o percentual de cada uma dessas estratégias em relação às demais, estabelecendo paralelos com outros estudos semelhantes no intuito de verificar se nossos dados corroboram com essas pesquisas e ou se são dissonantes. No último caso, espera-se identificar quais fatores contribuíram para essa disparidade.

Em seguida, procederemos um estudo do OI anafórico a partir do tipo de verbo, seguindo a tipologia proposta por Berlinck (1996). Verificamos quais verbos favorecem determinadas estratégias e, novamente, se esse favorecimento já foi atestado por outros trabalhos.

\footnotetext{
${ }^{33}$ Para Marcuschi (2002), Tipologia Textual é um termo que deve ser usado para designar uma espécie de sequência teoricamente definida pela natureza linguística de sua composição. Em geral, os tipos textuais abrangem as categorias narração, argumentação, exposição, descrição e injunção (Swales, 1990; Adam, 1990; Bronckart, 1999). Segundo ele, o termo Tipologia Textual é usado para designar uma espécie de sequência teoricamente definida pela natureza linguística de sua composição (aspectos lexicais, sintáticos, tempos verbais, relações lógicas) (MARCUSCHI, 2002, p. 22).
} 
Por fim, focamos nas realizações não anafóricas do OI, no intuito de certificar se em fase de letramento o aluno já apresenta a preferência por para em detrimento de $a$, já confirmada por diferentes trabalhos diacrônicos e sincrônicos, e, na subseção seguinte, qual tipo verbal favoreceria uma ou outra realização.

Verificamos, assim, se exatamente nessa fase escolar em que, em tese, o aluno é apresentado às formas de prestígio (clítico e $\mathrm{SN}$ precedido por $a$ ), o aluno acabe reproduzindo-as em seu texto, uma vez que sua Língua-I está acrescida de uma periferia de regras estilísticas adquiridas durante a escolaridade e que se reflete na sua língua escrita. Como vimos nos capítulos anteriores, Kato, Cyrino \& Correia (2009) afirma que o indivíduo educado, em ambas as modalidades, oral e escrita, faz um tipo de "code switching" entre as formas licenciadas por sua gramática nuclear e as formas aprendidas na escola. Há assim um input do vernáculo e um input estilístico.

Apesar de não ser o foco deste trabalho, consideramos ser pertinentes apontar alguns trechos que revelam outras formas em variação que surgiram nos dados analisados. Por não ser o cerne desta dissertação, tal seção é apenas expositiva e não temos o intuito de aprofundar em análises mais elaboradas.

\subsection{Metodologia e corpus}

Pretende-se fazer um estudo empírico das variantes da realização do OI, tomando como corpus redações de alunos do EF2, de duas escolas urbanas da cidade de Santos, sendo uma particular e uma pública. Assim, de cada série, foram tomadas 20 ocorrências, 10 do colégio particular e 10 do colégio público, compreendendo um total de 80 textos.

As redações apresentam estrutura narrativa ${ }^{34}$ e foram produzidos por alunos do $6^{\circ}$ ao $9^{\circ}$ ano com idades entre 10 e 14 anos.

Durante o EF2, os alunos são apresentados a diferentes gêneros textuais, alguns com tipologia narrativa; outros, argumentativa. Escolheu-se a narração pela facilidade encontrada pelo aluno na elaboração desse tipo de texto, mas, sobretudo, pelas marcas de oralidade que podemos encontrar em seu desenvolvimento. De acordo com Luzio e Rodrigues (2009), em um texto narrativo encontramos alguns marcadores conversacionais típicos de uma linguagem menos formal, pois na narração há a presença de atores múltiplos que se apresentam por ações

\footnotetext{
${ }^{34}$ Alguns textos do $9^{\circ}$ ano da escola pública apresentam trechos argumentativos, mas são essencialmente textos narrativos.
} 
e falas. Além de ser um texto mais voltado a um léxico concreto, construído para garantir a verossimilhança dos acontecimentos e, assim, permitir maior liberdade, inclusive sintática. Por esta razão, em um contínuo dos gêneros textuais entre a fala e a escrita, proposto por Marcuschi (2008), observamos que, apesar de estar inserido no eixo da escrita, a narrativa mostra-se mais perto da oralidade do que os textos argumentativos.

Por outro lado, a dissertação, por suas especificidades - defesa de ideias e argumentação - caracteriza-se por um gênero que requer escolha lexical mais abstrata e construções sintáticas voltadas aos padrões normativos, por este motivo é apresentada aos alunos na fase final do EF2.

No entanto, como se trata de um texto escrito, embora narrativo, no momento da produção o aluno exige mais do seu conhecimento linguístico, ou seja, "policia"-se com mais rigidez, para que não ocorra "erro". Fato este mais evidente se levarmos em consideração que, para o aluno, o texto é uma atividade avaliativa na qual deve reproduzir as variantes de prestígio para que alcance uma boa nota.

As professoras ${ }^{35}$ das escolas pública e particular solicitaram aos alunos diferentes propostas de redação seguindo os mesmos critérios tipológicos e as mesmas orientações, tais como observância ao tema e escolha do foco narrativo. Cada uma dessas propostas foi coerente com a faixa etária e o nível de aprendizado dos mesmos.

Foram coletadas aleatoriamente 10 redações em cada sala. São esses 80 textos narrativos, 40 produzidos por alunos de escola pública e 40 produzidos por alunos de escola particular, o corpus da pesquisa. Os dados foram codificados de modo a identificar pelas letras L (Liceu Santista - escola particular) e E (Edméa Ladevig - escola pública); pelos seguintes números: 6 ( $6^{\circ}$ ano), 7 ( $7^{\circ}$ ano), 8 ( $8^{\circ}$ ano) e 9 ( $9^{\circ}$ ano); em seguida, optou-se pelo uso do hífen para separar o número do informante. L6-02, por exemplo, refere-se à redação do aluno 02 da escola particular, do $6^{\mathbf{a}}$ ano.

\subsection{Resultados gerais do OI anafórico}

Iniciaremos a apresentação dos nossos resultados olhando para as realizações do OI anafórico. Conforme foi demonstrado no segundo capítulo, os trabalhos acadêmicos que tratam da realização do objeto indireto anafórico de $3^{\mathrm{a}}$ pessoa registram a ocorrência de três

\footnotetext{
${ }^{35} \mathrm{Na}$ escola pública, há uma professora diferente para cada ano. Na escola particular, uma para o $6^{\circ}$ ano; outra no $8^{\circ}$, e, ainda, uma terceira para o $7^{\circ}$ e $9^{\circ}$ (são nessas duas últimas em que leciono). No total, os textos foram solicitados por 7 professoras diferentes, porém todos seguiram a mesma tipologia textual.
} 
variantes: OI nulo, OI clítico (lhe/lhes) e OI preposicional. O mesmo ocorre nos resultados como podemos verificar nas duas tabelas (19) e (20) abaixo, onde apresentamos os dados gerais.

Tabela 19 - Realização do OI anafórico por ano escolar - Escola Pública

\begin{tabular}{|l|c|c|c|c|c|c|c|c|}
\cline { 2 - 9 } \multicolumn{1}{c|}{} & \multicolumn{2}{c|}{$\boldsymbol{\sigma}^{\boldsymbol{o}}$} & \multicolumn{2}{c|}{$\boldsymbol{7}^{\boldsymbol{0}}$} & \multicolumn{2}{c|}{$\boldsymbol{8}^{\boldsymbol{o}}$} & \multicolumn{2}{c|}{$\mathbf{9}^{\boldsymbol{o}}$} \\
\cline { 2 - 9 } \multicolumn{1}{c|}{} & $\mathrm{n}$. & $\%$ & $\mathrm{n}$. & $\%$ & $\mathrm{n}$. & $\%$ & $\mathrm{n}$. & $\%$ \\
\hline OI nulo & 13 & $81,25 \%$ & 47 & $70,15 \%$ & 9 & $90,00 \%$ & 4 & $80 \%$ \\
\hline $\begin{array}{l}\text { Pronome } \\
\text { clítico }\end{array}$ & 0 & $0,00 \%$ & 8 & $11,94 \%$ & 0 & $0,00 \%$ & 0 & $0 \%$ \\
\hline $\begin{array}{l}\text { Prep + } \\
\text { pronome }\end{array}$ & 3 & $18,75 \%$ & 12 & $17,91 \%$ & 1 & $10,00 \%$ & 1 & $20 \%$ \\
\hline
\end{tabular}

Verificamos na tabela que o total geral de OI nulo na escola pública alcançou um percentual muito alto nos quatro anos, chegando a $90 \%$ no $8^{\circ}$. Por outro lado, o pronome clítico foi totalmente ausente em três diferentes anos. A exceção foi o $7^{\circ}$ ano, com 11,94\%, ainda assim, um percentual baixo. A estratégia preposição+pronome embora com índices mais altos do que as realizações com pronome clítico, ainda está muito inferior ao OI nulo, alcançando $20 \%$ no $9^{\circ}$ ano e apenas $10 \%$ no $8^{\circ}$.

No que se refere à escola particular, o olhar minucioso dos dados, tabela revela importantes informações acerca das realizações do OI utilizadas pelos alunos

Tabela 20 - Realização do OI anafórico por ano escolar - Escola Particular

\begin{tabular}{|l|c|c|c|c|c|c|c|c|}
\cline { 2 - 9 } \multicolumn{1}{c|}{} & \multicolumn{2}{c|}{$\boldsymbol{6}^{\mathbf{0}}$} & \multicolumn{2}{c|}{$\boldsymbol{7}^{\boldsymbol{0}}$} & \multicolumn{2}{c|}{$\boldsymbol{8}^{\boldsymbol{0}}$} & \multicolumn{2}{c|}{$9^{\boldsymbol{0}}$} \\
\cline { 2 - 9 } \multicolumn{1}{c|}{} & $\mathrm{n}$. & $\%$ & $\mathrm{n}$. & $\%$ & $\mathrm{n}$. & $\%$ & $\mathrm{n}$. & $\%$ \\
\hline OI nulo & 24 & $92,31 \%$ & 18 & $90,00 \%$ & 25 & $96 \%$ & 14 & $82,35 \%$ \\
\hline $\begin{array}{l}\text { Pronome } \\
\text { clítico }\end{array}$ & 0 & $0,00 \%$ & 0 & $0,00 \%$ & 0 & $0 \%$ & 0 & $0,00 \%$ \\
\hline $\begin{array}{l}\text { Prep + } \\
\text { pronome }\end{array}$ & 2 & $7,69 \%$ & 2 & $10,00 \%$ & 1 & $4 \%$ & 3 & $17,65 \%$ \\
\hline
\end{tabular}

A princípio, sobressai a total ausência de clíticos em todas as séries, ou seja, nenhum aluno utilizou a forma dativa lhe/lhes de $3^{\text {a }}$ pessoa em seus textos. Por outro lado, vemos que a estratégia escolhida foi, assim como na escola pública, o OI nulo, o qual atingiu índices 
superiores a $85 \%$ em todas as séries. As realizações com preposição+pronome apresentam índices menores se comparadas com a escola pública, chegando a 7,69\% no $6^{\circ}$ ano, $10 \%$ no $7^{\circ}$, apenas $4 \%$ no $8^{\circ}$ ano e o índice mais alto, $17,65 \%$ no $9^{\circ}$ ano.

A seguir, analisaremos separadamente essas realizações.

\subsubsection{Objeto nulo}

Como vimos acima, o objeto nulo apresenta-se como a forma preferida pelos alunos para a realização do OI anafórico, variando entre $70 \%$ e $96 \%$. Tal forma é muito superior às outras estratégias em todas as séries nas duas escolas. Se compararmos somente a realização com OI nulo com o uso do pronome tônico precedido de preposição, constataremos mais claramente essa supremacia (conf. Gráfico 14).

Gráfico 12 - Realização da forma plena e nula do OI, de acordo com o ano escolar na escola pública e privada

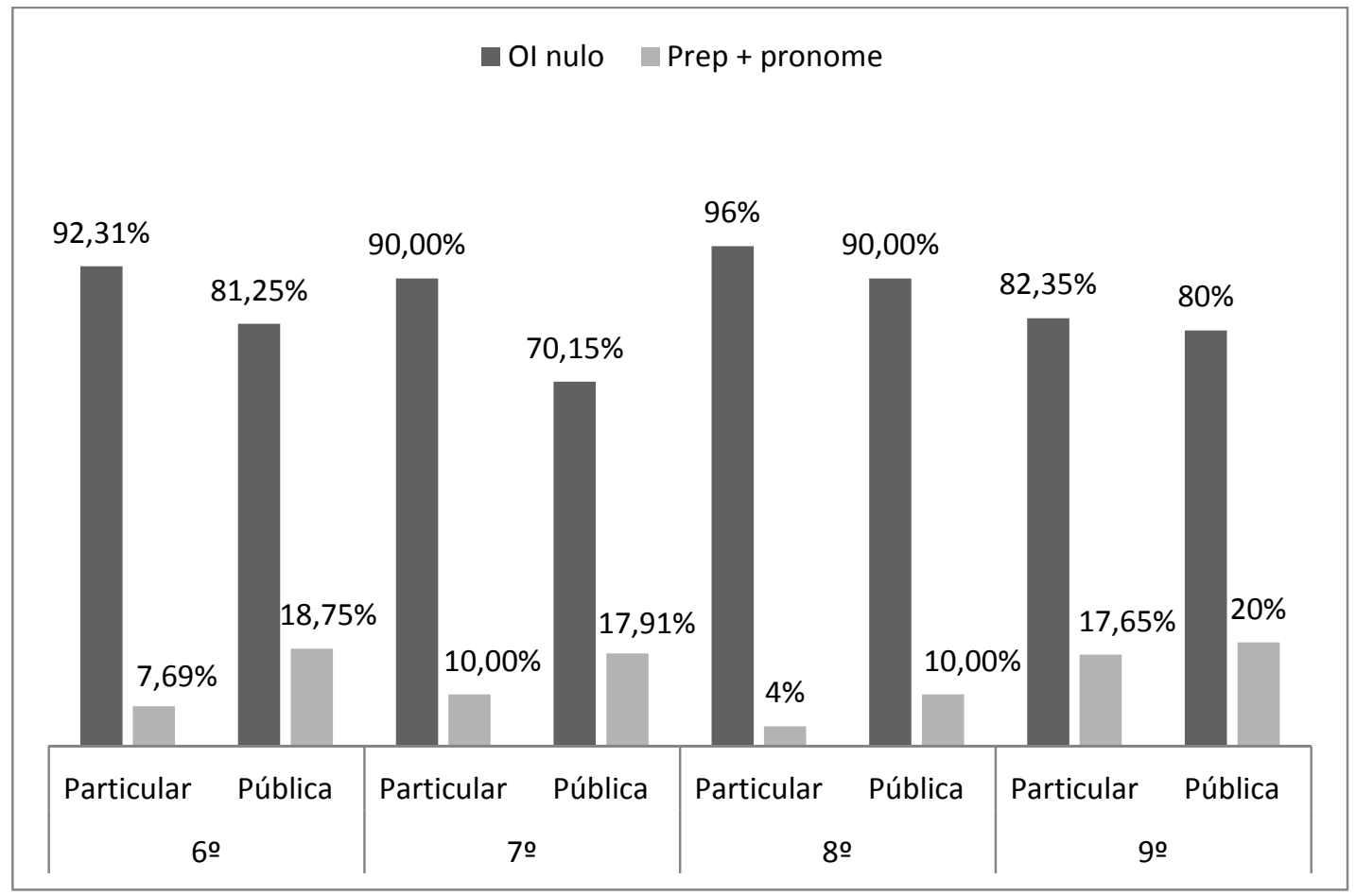

Ambas as estratégias, tanto da realização pronominal quanto do objeto nulo são interessantes, pois sabemos que têm baixíssima produção no PE, como mostrado em Freire (2005). Apesar de menos produtiva do que o OI nulo, a realização plena foi identificada em todas as séries das duas escolas, a pública e a particular, conforme exemplos abaixo: 
(35) a. ...Jack era o melhor também na faculdade, mas ele era tão bom que [eles $]_{\mathrm{N} 0}$ ofereceram uma vaga ${ }_{\mathrm{N} 1}$ para ele $_{\mathrm{N} 2}$ na faculdade na Inglaterra

b. qualdo estiver acabando o dinheiro, $[\theta]_{\mathrm{N} 0}$ peso para ele ${ }_{\mathrm{N} 2} \operatorname{voltar}_{\mathrm{N} 1} \ldots$

(36) a. ...[eu $]_{\mathrm{N} 0}$ perguntei a ele $\underline{\mathrm{N}}_{2}$ se esteve na casa do escritor falecido $\mathrm{N}_{\mathrm{N}}$

b. ...não era para $[\theta]_{\mathrm{N} 0}$ dar o endereço $\mathrm{N}_{\mathrm{N} 1}$ para ela $_{\mathrm{N} 2}$

a. $[\mathrm{Eu}]_{\mathrm{N} 0}$ Entreguei a eles $\underline{\mathrm{N}}_{2}$ um graveto ${ }_{\mathrm{N} 1}$.

b. Na festa ofereceram droga a ela,

(38) a. Procurei um padre, e $[\mathrm{eu}]_{\mathrm{N} 0}$ perguntei $\underline{\text { ele }}_{\mathrm{N} 2}$.

Ainda no gráfico 14, ao observarmos os valores percentuais de realizações com preposição+pronome, percebemos que não há um equilíbrio no uso dessa variante entre as séries das duas escolas. No $6^{\circ}$ ano, por exemplo, foram identificadas $7,69 \%$ das ocorrências na escola particular e 18,75\% na pública, uma diferença de 11,06\%. O mesmo quadro é parecido em todas as séries, com exceção do $9^{\circ}$ ano cuja diferença entre os dados percentuais entre as duas escolas foi de apenas $2,35 \%$.

Apesar de observamos realizações com OI pleno, como dito, estas são muito inferiores àquelas com OI nulo. Essa preferência parece contradizer os dados levantados por Freire (2005) em cujo estudo identificou uma maior realização de SP anafórico, 42\%, contra 32\% de OI nulo.

Essa divergência, porém, pode estar relacionada ao tipo de corpus utilizado em ambas as pesquisas. Enquanto Freire (2005) focou em amostras de jornais e revistas, este estudo abordou redações produzidas por alunos, os quais ainda se encontram em período de letramento. Podemos verificar exemplos de realizações com OI nulo nas ocorrências abaixo extraídas das escolas particular (39) e pública (40) : 
(39) a. Se passou uma semana e ele recebeu uma carta dizendo que Jack estava vivo mas com dores. Herry ${ }_{\mathrm{N} 0}$ pediu $[\theta]_{\mathrm{N} 2}$ o helicoptero imprestado $_{\mathrm{N} 1}$ e foi para a Inglaterra.

b. ...então o detetive foi até ele e [o detetive $]_{\mathrm{N} 0}$ perguntou $[\theta]_{\mathrm{N} 2}$ se ele sabia de algo sobre a morte do escritor...N1

c. - Você sempre teve mania de grandeza 1

Disse $[\theta]_{\mathrm{N} 2}$ Melvin $_{\mathrm{N} 0}$

d. Eu a perdoei, mas $[\mathrm{eu}]_{\mathrm{N} 0}$ pedi $[\theta]_{\mathrm{N} 2}$ meu divórcio ${ }_{\mathrm{N} 1}$.

(40) a. Certo dia o Luís $\mathrm{N}_{\mathrm{N} 0}$ não aguento mas e falou $[\theta]_{\mathrm{N} 2}$, Eí garoto você ${ }_{\mathrm{N} 1}$.

b. - Você quem é filho de José, Lucas? ${ }_{\mathrm{N} 1} \operatorname{Dizia}[\theta]_{\mathrm{N} 2}$ um homem estranho ${ }_{\mathrm{N} 0}$, chamado Tonhão

a. Depois ela começa a se prostituir com os velhos $\mathrm{N}_{\mathrm{N} 0}$ que dão $[\theta]_{\mathrm{N} 2}$ muito dinheiro $_{\mathrm{N} 1}$ e aí ela pega o vírus da aids.

d. Comovida, Sophia ${ }_{\mathrm{N} 0} \operatorname{diz}[\theta]_{\mathrm{N} 2}$ :

- Nossa, desculpe mãe,...N1

Como vemos esses usos relacionam-se com a estrutura narrativa. Ora, sabemos que na elaboração do gênero narrativo, há o favorecimento do uso de verbos dicendi. Como apontado por Cyrino, Nunes e Pagotto (2009, p. 78) estes verbos podem ser transitivos ou bitransitivos, já que o destinatário nessas sentenças seria uma espécie de adjunto não necessário na estrutura $\operatorname{argumental}^{36}$, portanto o apagamento do OI não comprometeria a compreensão do texto.

A afirmação dos autores citados reitera o trabalho de Benvenutti (2002, p. 145), segundo o qual "o apagamento pronominal tem, na seleção da variante dicendi para complemento nulo, sua mais importante caracterização". Para Freire (2005), pode-se supor que é em contextos representados por verbos bitransitivos dicendi o ponto de partida da mudança linguística na expressão do dativo anafórico de terceira pessoa.

\footnotetext{
${ }^{36}$ Aprofundaremos essa análise adiante na descrição dos dados de acordo com os tipos de verbos.
} 
Por outro lado, é preciso ressaltar que com verbos dicendi há outra possibilidade, a do OI com sentido arbitrário. Neste caso, não temos um antecedente explícito.

$\mathrm{O}$ alto índice de nulos também pode estar associado ao fato de que, para o aluno, o OI pode ser resgatado dentro do discurso como um elemento [+ animado] e [+ humano], ou seja, o OI está claramente tratado e pode ser retomado no discurso, não sendo necessário seu preenchimento.

Vale notar que as ocorrências de OI nulo extraídas do corpus exemplificam não só o OI nulo com referência anafórica (conf. exemplo (41)) como também expõe ocorrências do OI nulo de referência arbitrária (conf. exemplos (42) e (43)), ou seja, objetos indiretos em que não há referente no contexto linguístico ${ }^{37}$

(41) Logo depois de sua saída peguei o telefone para ligar para a polícia. $[\mathrm{Eu}]_{\mathrm{N} 0}$ Expliquei $[\theta]_{\mathrm{N} 2} \operatorname{tudo}_{\mathrm{N} 1} \ldots$

(42) $\operatorname{Todos}_{\mathrm{N} 0}$ dizem $[\theta]_{\mathrm{N} 2}$ que alienígenas são mais evoluídos que o ser humano que possuem máquinas inexistentes na Terra e que um dia poderiam nos transformar em escravos. 1

(43) Relatos ${ }_{\mathrm{N} 0}$ contavam $[\theta]_{\mathrm{N} 2}$ que seres não codificados realizavam de madrugada...N1

Observa-se que na comparação entre as séries, não se observa uma diminuição do OI nulo com o aumento da escolaridade, ou seja, não houve aquisição dos clíticos e a estratégia preposicionada também não foi a mais utilizada. Como visto no capítulo 2, Santos (2007) afirma que a escolarização foi responsável diretamente pela diminuição do OI nulo no seu corpus. Nesta pesquisa também realizada com alunos ${ }^{38}$, o autor identificou essa hegemonia no uso da forma nula, mas com um decréscimo marcado durante a escolaridade: de $54,35 \%$ no $6^{\circ}$ ano para $30,77 \%$ no $3^{\circ}$ ano do Ensino Médio.

\footnotetext{
${ }^{37}$ Moretti (2010) denomina como OI implícito casos em que o argumento não é realizado fonologicamente, mas é projetado na sintaxe. Em exemplos, como

a. Depois do regime, Maria deu [Ø] todas as roupas que não serviam mais.

b. O médico receitou $[\varnothing]$ um remédio muito bom.

${ }^{38}$ Ver capítulo 2
} 
Se selecionarmos neste estudo de Santos somente os dados referentes ao EF2 (conf. tabela 21), verificamos que o decréscimo de nulo é bem menor, apenas 10,21\%, ou seja, passa de $54,35 \%$ no $6^{\circ}$ ano, para $44,14 \%$ no $9^{\circ}$.

Tabela 21 - Realização do OI nulo no EF2 - Atividade mais monitorada

\begin{tabular}{|l|c|c|c|c|}
\hline & $\boldsymbol{6}^{\boldsymbol{o}}$ & $\mathbf{7}^{\boldsymbol{0}}$ & $\boldsymbol{8}^{\boldsymbol{o}}$ & $\mathbf{9}^{\boldsymbol{o}}$ \\
\hline Objeto nulo & $54,35 \%$ & $51,13 \%$ & $44,04 \%$ & $44,14 \%$ \\
\hline
\end{tabular}

Com relação aos nossos dados, elaboramos uma tabela (22) a partir de uma média aritmética simples entre as porcentagens encontradas nas redações das escolas pública e particular e obtivemos os seguintes índices para esse mesmo uso:

Tabela 22 - Realização do OI nulo no EF2 - Escola Pública e Particular

\begin{tabular}{|l|c|c|c|c|}
\hline & $\boldsymbol{6}^{\boldsymbol{o}}$ & $\mathbf{7}^{\boldsymbol{0}}$ & $\boldsymbol{8}^{\boldsymbol{o}}$ & $\mathbf{9}^{\boldsymbol{o}}$ \\
\hline Objeto nulo & $86,78 \%$ & $80,07 \%$ & $93 \%$ & $81,17 \%$ \\
\hline
\end{tabular}

Percebemos que no estudo de Santos (2007) a diminuição das formas nulas do OI já ocorre nas séries do EF2, como apontado pela tabela (21), onde podemos acompanhar um percurso que se estende do $6^{\circ}$ ao $9^{\circ}$ ano com uma gradativa diminuição desses usos. Santos interpreta esses resultados baseando-se no tipo de corpus, composto por uma atividade, denominado por ele, mais monitorada.

Nos nossos dados, por outro lado, não vemos esse decréscimo (conf. Tabela (22)). O percentual de OI nulo anafórico apresenta-se sempre acima de $80 \%$, chegando a $93 \%$ no $8^{\circ}$ ano.

Essa discrepância entre os resultados de Santos e os nossos pode também ser atribuída a essa diferença de corpus utilizado. Como dito, os dados do autor foram colhidos em atividades mais monitoradas em que aos alunos cabia a transposição para o discurso indireto de cenas retratadas em determinados quadrinhos. Chamamos de mais monitorada, pois a própria atividade já trazia alguns complementos verbais realizados, levando aos alunos a uma cópia dessa forma. Provavelmente os alunos do $9^{\circ}$ ano foram mais sensíveis ao monitoramento, pois neste ano escolar já teriam sido apresentados a conteúdos pertinentes à complementação verbal. 
Já em uma atividade chamada por Santos (2007) de menos monitorada em que o aluno teve total liberdade de escrita, os resultados encontrados mostraram-se mais próximos dos obtidos por nós, conforme tabela (23).

Tabela 23 - Realização do OI nulo no EF2 - Atividade menos monitorada

\begin{tabular}{|l|c|c|c|c|}
\hline & $\boldsymbol{6}^{\boldsymbol{o}}$ & $\mathbf{7}^{\boldsymbol{0}}$ & $\boldsymbol{8}^{\boldsymbol{o}}$ & $\boldsymbol{9}^{\boldsymbol{o}}$ \\
\hline Objeto nulo & $82,56 \%$ & $69,84 \%$ & $72,98 \%$ & $61,68 \%$ \\
\hline
\end{tabular}

Por fim, a tabela (24) apresenta os resultados decorrentes da comparação entre os dois universos escolares, o público e o particular. Pelos resultados, o que se nota é uma regularidade. Sendo que os aprendizes da escola particular apresentam os mais altos índices, em todas as séries, de preferência pelo uso da forma nula, acima de $80 \%$.

Tabela 24 - Realização do OI nulo, por ano escolar na escola pública e particular

\begin{tabular}{|c|c|c|c|c|c|c|c|c|}
\hline & \multicolumn{2}{|c|}{$6^{o}$} & \multicolumn{2}{|c|}{$7^{o}$} & \multicolumn{2}{|c|}{$8^{o}$} & \multicolumn{2}{|c|}{$9^{\circ}$} \\
\hline & Particular & Pública & Particular & Pública & Particular & Pública & Particular & Pública \\
\hline OI nulo & $92,31 \%$ & $81,25 \%$ & $90,00 \%$ & $70,15 \%$ & $96 \%$ & $90,00 \%$ & $82,35 \%$ & $80 \%$ \\
\hline
\end{tabular}

O ano que apresentou maior diferença entre os dados foi o $7^{\circ}: 90 \%$ na escola particular e 70,15\% na escola pública. Nos demais, a diferença entre o percentual apresentado na escola pública e a particular foi de $11,06 \%$, no $6^{\circ}$ ano; $6 \%$, no $8^{\circ}$ e chegando a apenas $2,35 \%$, no $9^{\circ}$ ano.

Esses índices foram nossa primeira evidência de que fatores socioeconômicos não interferem na gramática dos falantes, no caso específico do fenômeno estudado, pois os alunos da escola pública e particular apresentaram a preferência pela mesma estratégia na substituição do clítico dativo de $3^{\mathrm{a}}$ pessoa, o OI nulo.

Vejamos, então, se tal parâmetro se mantém nas outras realizações de OI.

\subsubsection{Clítico}

Inúmeros estudos já atestaram o declínio no uso do clítico de $3^{\mathrm{a}}$ pessoa, sendo esta variante característica do PE. Freire (2005), como dito no capítulo 2, apontou 9\% de uso de clíticos em textos da imprensa brasileira. Logo, se em falantes letrados esses índices já se mostraram baixos em alunos ainda em processo escolar, esperava-se a mesma situação. 
Em uma primeira exploração dos meus dados (conf. Tabela (25) e (26)), o que sobressai é a total ausência dessa realização de OI clítico anafórico. Com exceção do $7^{\circ}$ ano da escola pública, em todas as outras séries, o clítico dativo de terceira pessoa não foi realizado.

Tabela 25 - Realização do pronome clítico, por ano escolar na escola pública

\begin{tabular}{|c|c|c|c|c|c|c|c|c|}
\hline & \multicolumn{2}{|c|}{$6^{o}$} & \multicolumn{2}{|c|}{$7^{o}$} & \multicolumn{2}{|c|}{$8^{\circ}$} & \multicolumn{2}{|c|}{$9^{o}$} \\
\hline & $\mathrm{n}$. & $\%$ & $\mathrm{n}$. & $\%$ & $\mathrm{n}$. & $\%$ & $\mathrm{n}$. & $\%$ \\
\hline $\begin{array}{l}\text { Pronome } \\
\text { clítico }\end{array}$ & 0 & $0,00 \%$ & 8 & $11,94 \%$ & 0 & $0,00 \%$ & 0 & $0 \%$ \\
\hline
\end{tabular}

Tabela 26 - Realização do pronome clítico, por ano escolar na escola particular

\begin{tabular}{|l|c|c|c|c|c|c|c|c|}
\cline { 2 - 9 } \multicolumn{1}{c|}{} & \multicolumn{2}{c|}{$\boldsymbol{6}^{\boldsymbol{o}}$} & \multicolumn{2}{c|}{$\boldsymbol{7}^{\boldsymbol{0}}$} & \multicolumn{2}{c|}{$\boldsymbol{8}^{\boldsymbol{o}}$} & \multicolumn{2}{c|}{$\mathbf{9}^{\boldsymbol{o}}$} \\
\cline { 2 - 9 } \multicolumn{1}{c|}{} & $\mathrm{n}$. & $\%$ & $\mathrm{n}$. & $\%$ & $\mathrm{n}$. & $\%$ & $\mathrm{n}$. & $\%$ \\
\hline $\begin{array}{l}\text { Pronome } \\
\text { clítico }\end{array}$ & 0 & $0,00 \%$ & 0 & $0,00 \%$ & 0 & $0 \%$ & 0 & $0,00 \%$ \\
\hline
\end{tabular}

Ou seja, apesar do clítico ainda ser considerado a forma culta padrão "ensinada" na escola, nossos dados apontaram para uma quase total extinção dessa realização mesmo na escrita.

Conforme dissemos acima, não nos surpreenderia que tal estratégia fosse a menos utilizada pelos alunos, porém a total rejeição dessa variante foi um impacto. Mesmo se considerarmos apenas o $7^{\circ}$ ano da escola pública, ainda assim, a porcentagem de clítico é discrepante diante das outras realizações dessa mesma série. No $7^{\circ}$ ano da escola pública foram identificadas 67 ocorrências de OI anafórico, apenas 8 realizadas com clítico dativo, resultando em índices percentuais muito baixos em cada tipo de verbo. 
Tabela 27 - Realização de clítico dativo de terceira pessoa de acordo com o tipo verbal no $7^{\circ}$ ano da Escola Pública

\begin{tabular}{|l|c|c|}
\hline \multicolumn{1}{|c|}{ Tipo de verbo } & \multicolumn{2}{c|}{$7^{\text {o }}$} \\
\hline Transferência verbal e perceptual & n. & $\begin{array}{c}\text { \% em relação ao total de realizações } \\
\text { anafóricas da série escolar. }\end{array}$ \\
\hline Transferência material & 03 & $4,48 \%$ \\
\hline Movimento físico & 05 & $7,5 \%$ \\
\hline Movimento abstrato & ----- & ------- \\
\hline
\end{tabular}

Outro aspecto interessante é que supondo que tal uso está relacionado com o aprendizado escolar, imagina-se que esta variante seja mais realizada no último ano do ensino fundamental, já que o aluno já teria adquirido, por meio da educação formal, subsídios linguísticos referentes ao padrão culto da língua. Causou-nos estranhamento, portanto, que todas as ocorrências do clítico lhe tenham sido identificadas no $7^{\circ}$ e não no $9^{\circ}$ ano.

Assim sendo, investigamos esses dados e identificamos que das oito ocorrências de pronome clítico de $3^{a}$ pessoa, quatro foram identificadas no mesmo falante. Ou seja, metade do índice é reproduzido pelo mesmo aluno. Tal fato pode corroborar o que Kato, Cyrino e Corrêa (2009) afirmam, ou seja, a morfossintaxe aprendida na escola tem estatuto estilístico e não gramatical.

Este aluno produziu as seguintes ocorrências:

(44) ...com um homem estranho, baixinho e gorducho ${ }_{\mathrm{N} 0}$, que $\underline{\text { lhe }}_{\mathrm{N} 2}$ perguntou se era filho de José́ ${ }_{\mathrm{N} 1} \ldots$

(45) Ele ${ }_{\mathrm{N} 0} \underline{\text { lhe }}_{\mathrm{N} 2}$ indicou o caminho $\mathrm{N}_{\mathrm{N} 1}$ para sua mercearia...

(46) Mariana queria o seu endereço para $[\text { Mariana }]_{\mathrm{N} 0} \underline{\text { lhe }}_{\mathrm{N} 2} \operatorname{escrever}[\theta]_{\mathrm{N} 1}$

(47) Tonhão $\mathrm{N}_{\mathrm{N} 0}$ tinha $\underline{\operatorname{lhe}}_{\mathrm{N} 2}$ dado um bolo de dinheiro $\mathrm{N}_{1}$.

Chama-nos à atenção, ainda, a posição do pronome na sentença. Há nítida preferência pela próclise, ainda que algumas sentenças não possuam a partícula atratora que justifique essa colocação. Novamente, vemos a mesma ideia de que a escola resgata os clíticos, mas não a gramática de sua colocação. 
Assim, como Freire (2011) aponta, o uso dos clíticos em situações diferentes sem uma aparente normatização pode evidenciar a artificialidade das variantes consideradas de prestígio pela tradição gramatical no dialeto dos alunos, sinalizando a insuficiência das estratégias utilizadas pela escola na tentativa de ensiná-las aos aprendizes.

Verificamos, ainda, que o mesmo aluno que preencheu o OI por meio de clítico, também utilizou outras variantes, tais como, o objeto nulo e OI lexical antecedido por para ${ }^{39}$, como os exemplos abaixo.

(48) ...por um salário medíocre, que [Lucas $]_{\mathrm{N} 0}$ mandava quase todo $\mathrm{N}_{\mathrm{N} 1}$ para sua $\underline{\text { mãe }}_{\mathrm{N} 2}$.

(49) ...a primeira coisa que [Mariana $]_{\mathrm{N} 0}$ disse $[\theta]_{\mathrm{N} 2}$ foi:

- Você não sabe o que eu fiz...N1

Ou seja, se por um lado, o aluno reproduz a forma de prestígio, esta se encontra em competição com outras realizações de OI menos valorizadas. O mesmo ocorreu em um texto de outro aluno, onde se observam realizações do OI de maior e menor prestígio: pronome clítico, objeto nulo e preposição+pronome.

(50) a. O estranho ${ }_{\mathrm{N} 0}$ deu $\underline{\operatorname{lhe}}_{\mathrm{N} 2}$ uns tapinhas nas $\operatorname{costas}_{\mathrm{N} 1}$ de Lucas

b. $\operatorname{Lucas}_{\mathrm{N} 0}$ não queria falar $[\theta]_{\mathrm{N} 2}$ so isso $\mathrm{N}_{1}$

c. $\quad \ldots[\text { Lucas }]_{\mathrm{N} 0}$ queria dizer a ela ${ }_{\mathrm{N} 2}$ seu $\operatorname{amor}_{\mathrm{N} 1}$

Podemos, então supor que talvez, para os alunos, o texto narrativo não tenha o grau de formalidade que, possivelmente, encontramos nos textos argumentativos, fato este que não incita ao uso de formas consideradas mais cultas, como os clíticos. Ainda que essas produções tenham caráter avaliativo.

Além disso, o fato da forma considerada culta, clítico the, ter sido produzida exclusivamente pelos alunos do ensino público ratifica o que dissemos anteriormente de que aspectos de ordem socioeconômicas não interferem no vernáculo das crianças. Ou seja, o poder aquisitivo, no que se refere ao objeto indireto, não é determinante para o uso da variante mais prestigiada. Supomos, portanto que seria o ambiente familiar e o estilo do falante

\footnotetext{
${ }^{39}$ As realizações de OI lexical precedido por $a$ e para serão analisadas na próxima seção.
} 
responsáveis pela fixação das formas de prestígio, nem que essas variantes se apresentem em competição com outras realizações do OI.

\subsubsection{Tipologia verbal na realização do OI anafórico}

Nesta seção descreveremos as realizações do OI anafórico de acordo com o tipo de verbo. Para isto, seguimos a tipologia de Berlinck (1996) que divide os verbos em: verbos de transferência verbal e perceptual, verbos de transferência material, movimento físico e movimento abstrato. (Conf. capítulo 2).

Como visto na seção 4.2.1, sobre objetos nulos, diante do tipo de texto solicitado, a narração, já supúnhamos encontrar maior realização de verbos de transferência verbal, ou dicendi, em detrimento a outros. Tal fato se confirmou, das 186 ocorrências de OI anafórico, 156 foram com verbos de transferência verbal e perceptual, ou seja, 83,87\% dos dados. O gráfico 16 abaixo confirma essa supremacia quase absoluta em algumas séries.

Gráfico 13 - Uso de verbos de transferência verbal e perceptual em ocorrências de OI anafórico

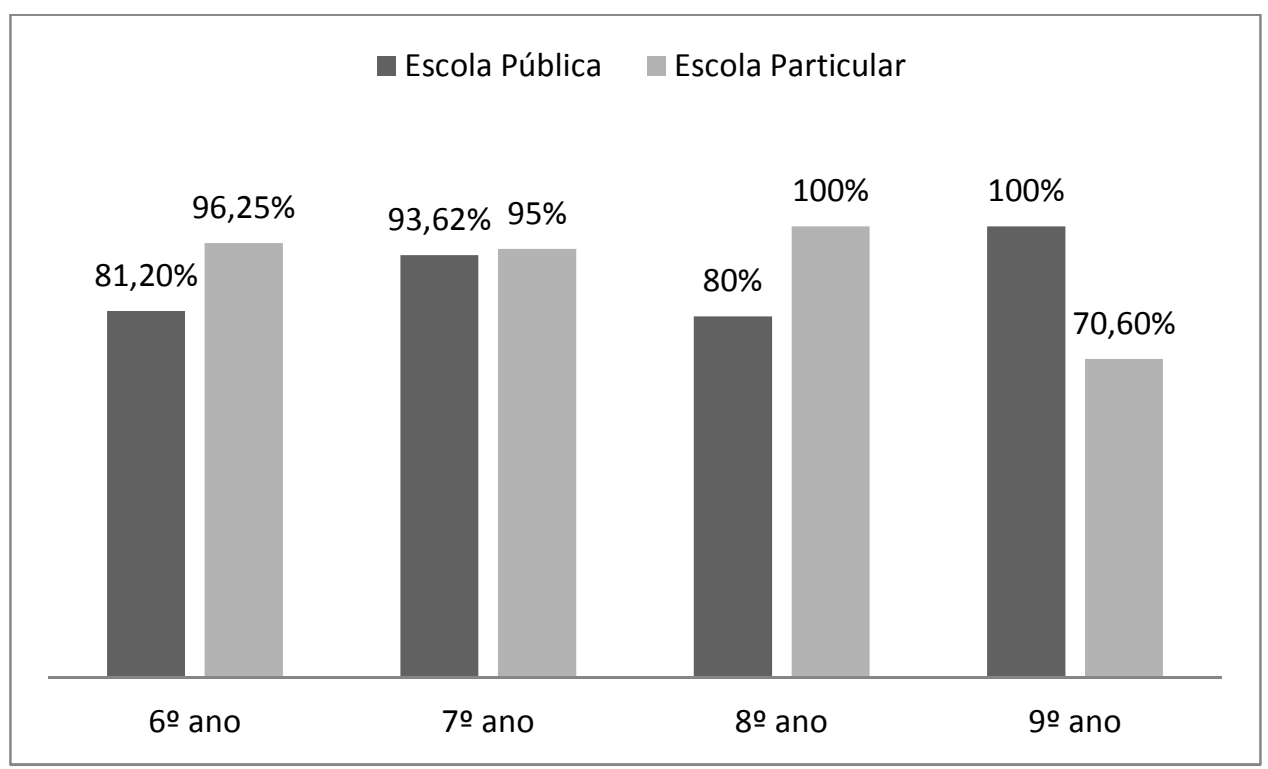

No $8^{\circ}$ ano da Escola Particular e no $9^{\circ}$ ano da Escola Pública verifica-se a total hegemonia no uso dos verbos de transferência verbal e perceptual, além disso, podemos perceber que em todas as séries os níveis foram extremamente altos, acima dos $70 \%$. Observamos, ainda, que não há discrepância entre os índices apontados pela escola pública e particular. 
Abaixo, observam-se alguns exemplos dessa realização em duas séries escolares, uma da escola pública e outra na particular.

(51) Ela No explicou $[\theta]_{\mathrm{N} 2}$ que se destruísse o planeta $\mathrm{N}_{\mathrm{N} 1}$ e o seu povo inútil poderia recomeçar a povoação do zero se tornaria a imperadora.

(52) ...todas as lindas palavras que um dia sonhava em $[e l a]_{\mathrm{N} 0} \operatorname{dizer}[\theta]_{\mathrm{N} 1}$ para a linda moça 2 ,

Nesses exemplos comprovamos como esses verbos são fundamentais na constituição da narrativa em que se estabelecem diálogos diretos e indiretos entre os personagens.

Consequentemente, nota-se pela tabela (28), que é especialmente com os verbos bitransitivos de transferência verbal e perceptual que o uso do objeto nulo se mostra mais produtivo nas duas escolas, ao todo foram identificados 142 casos de OI nulo nesses tipos de verbos, $92,20 \%$ das ocorrências.

Tabela 28 - Realização de OI nulo anafórico de acordo com o tipo verbal

\begin{tabular}{|l|c|c|c|c|c|c|c|c|}
\hline & \multicolumn{2}{|c|}{$\sigma^{\circ}$} & \multicolumn{2}{c|}{$7^{\circ}$} & \multicolumn{2}{c|}{$8^{\circ}$} & \multicolumn{2}{c|}{$9^{\circ}$} \\
\hline & Particular & Pública & Particular & Pública & Particular & Pública & Particular & Pública \\
\hline $\begin{array}{l}\text { Transferência } \\
\text { verbal e perceptual }\end{array}$ & 23 & 12 & 18 & 46 & 25 & 08 & 08 & 04 \\
\hline $\begin{array}{l}\text { Transferência } \\
\text { material }\end{array}$ & 01 & 01 & 00 & 01 & 00 & 01 & 05 & 00 \\
\hline Movimento físico & 00 & 00 & 00 & 00 & 00 & 00 & 01 & 00 \\
\hline $\begin{array}{l}\text { Movimento } \\
\text { abstrato }\end{array}$ & 00 & 00 & 00 & 00 & 00 & 00 & 00 & 00 \\
\hline
\end{tabular}

Observamos na tabela, situações bem similares entre as escolas. No $7^{\circ}$ ano da escola pública há 44 ocorrências de OI nulo em contextos de verbos de transferência verbal e perceptual e apenas 01 naqueles de transferência material. No $6^{\circ}$ ano da escolar particular a situação é bem semelhante, 23 casos de OI nulo com verbos de transferência verbal e perceptual e 01 de transferência material.

De maneira geral, podemos verificar pela tabela (29), essa total supremacia de OI nulo como complemento de verbos de transferência e movimento em relação às outras variantes. 
Tabela 29 - Porcentagem de realização de OI nulo anafórico de acordo com o tipo verbal em relação às outras variantes

\begin{tabular}{|l|c|c|c|c|c|c|c|c|}
\hline & \multicolumn{2}{|c|}{$\sigma^{\text {o }}$} & \multicolumn{2}{c|}{$7^{\circ}$} & \multicolumn{2}{c|}{$8^{\circ}$} & \multicolumn{2}{c|}{$9^{\circ}$} \\
\hline & Particular & Pública & Particular & Pública & Particular & Pública & Particular & Pública \\
\hline $\begin{array}{l}\text { Transferência } \\
\text { verbal e perceptual }\end{array}$ & $96 \%$ & $100 \%$ & $95 \%$ & $81 \%$ & $100 \%$ & $100 \%$ & $80 \%$ & $80 \%$ \\
\hline $\begin{array}{l}\text { Transferência } \\
\text { material }\end{array}$ & $50 \%$ & $25 \%$ & ------ & $11 \%$ & ----- & $50 \%$ & $83 \%$ & ----- \\
\hline $\begin{array}{l}\text { Movimento físico } \\
\text { Movstrato }\end{array}$ & ------ & ------ & ----- & ----- & ------ & ------ & $100 \%$ & ----- \\
\hline
\end{tabular}

O OI nulo mostrou-se como forma absoluta não só em alguns contextos de verbos de transferência verbal e perceptual como naqueles com verbos de movimento físico. Com relação aos verbos de transferência verbal, esses atingiram índice de $100 \%$ no $6^{\circ}$ ano da escola pública e no $8^{\circ}$ ano da escola pública e particular. Os menores índices de OI nulo foram encontrados com verbos de transferência material, fato este que será avaliado adiante.

Estes dados corroboram outros estudos, tais como Freire (2005), em cuja pesquisa apontou a categoria vazia como variante majoritária em contextos de verbos de transferência verbal com um índice de $62 \%$ em textos de imprensa.

Por outro lado, das 25 ocorrências com verbos de transferência material, 11 foram realizadas com OI nulo, 05 com clíticos dativos de $3^{\text {a }}$ pessoa e 09 com preposição+pronome. Lembrando que no total do corpus foram registradas apenas 08 ocorrências de clíticos. $\mathrm{Ou}$ seja, dessas 08 ocorrências, 03 foram realizadas em verbos de transferência verbal e 5 em verbos de transferência material. Tal fato parece indicar uma preferência da realização clítica nesses contextos, como vemos no gráfico (14). 
Gráfico 14 - Realizações do OI anafórico nos verbos de transferência material e verbal na escola pública e particular

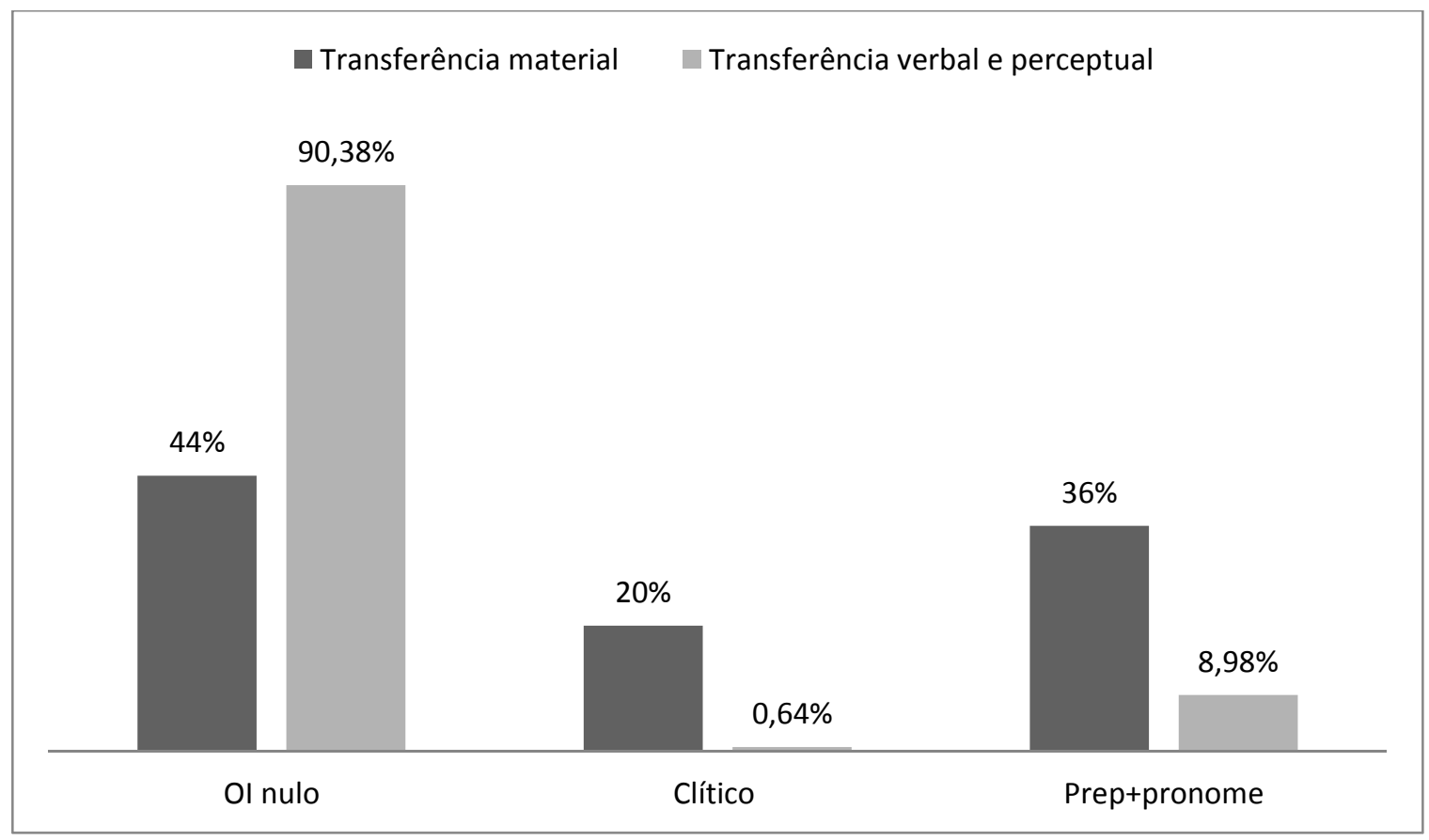

Pelos dados, fica evidente que OI nulo é a forma preferida pelos alunos em ambos os tipos de verbos, porém, os verbos de transferência material, na comparação com os de transferência verbal, apresentam índices elevados de realizações com preposição+pronome, $36 \%$ e clíticos, $20 \%$.

Essa preferência do clítico na realização com verbos de transferência material, a princípio, não corrobora a pesquisa de Freire (2005) o qual apontou preferência de SP anafórico nas realizações com verbos dandi $^{40}, 46 \%$; seguido pelos pronomes, $37 \%$ e, por último, $17 \%$ de objeto nulo. Por outro lado, se confrontarmos os dados obtidos em verbos dandi e dicendi nessa mesma pesquisa de Freire, observamos pontos em comum com nossos dados.

Tabela 30 - Função dativa: distribuição das variantes segundo o tipo de verbo

\begin{tabular}{|l|c|c|c|c|c|c|}
\hline PB & \multicolumn{2}{|c|}{ Clítico } & \multicolumn{2}{c|}{ SP anafórico } & \multicolumn{2}{c|}{ Objeto nulo } \\
\hline Bitransitivo dandi & $36 / 96$ & $37 \%$ & $44 / 96$ & $46 \%$ & $16 / 96$ & $17 \%$ \\
\hline Bitransitivo dicendi & $3 / 42$ & $7 \%$ & $13 / 42$ & $31 \%$ & $26 / 42$ & $62 \%$ \\
\hline
\end{tabular}

\footnotetext{
${ }^{40}$ Dandi refere-se a verbos de transferência material
} 
Tabela 31 - Função dativa: distribuição das variantes segundo o tipo de verbo

\begin{tabular}{|l|c|c|c|}
\hline & Clítico & SP anafórico & Objeto nulo \\
\hline Verbos de transferência material & $20 \%$ & $36 \%$ & $44 \%$ \\
\hline Verbos de transferência verbal & $0,64 \%$ & $8,98 \%$ & $90,38 \%$ \\
\hline
\end{tabular}

Nas duas pesquisas, há valores muito baixos de clíticos em verbos de transferência verbal, 7\% em Freire e 0,64\% em nossos dados; sendo que essa porcentagem sobe quando o contexto envolve os verbos de transferência material, $37 \%$ e $20 \%$, respectivamente . Além disso, o OI nulo é a forma preferida nos verbos de transferência verbal, 62\% em Freire e 90,38\% na nossa pesquisa. Não podemos ignorar, no entanto, que o corpus de Freire é composto por falantes letrados, enquanto o nosso, ainda encontra-se em processo de escolaridade, fato este que pode justificar as diferenças percentuais encontradas tanto na realização da forma clítica, muito mais abundantes em Freire e nos maiores índices de OI nulo identificados em nossos dados.

Podemos perceber, portanto, que, diferentemente dos verbos de transferência verbal e perceptual, os quais tem uso categórico de OI nulo, os verbos de transferência material permitem outras realizações, como o uso do SP (36\%) e clíticos, conforme exemplos abaixo: ...não era para $[\theta]_{\mathrm{N} 0}$ dar o endereço ${ }_{\mathrm{N} 1}$ para ela $_{\mathrm{N} 2}$

$$
\text { Tonhão }_{\mathrm{N} 0} \text { tinha } \underline{\operatorname{lhe}}_{\mathrm{N} 2} \text { dado um bolo de dinheiro }{ }_{\mathrm{N} 1} \text {. }
$$

O que verificamos, portanto, é que dentre os tipos de verbos, houve supremacia absoluta de verbos de transferência verbal e perceptual seguidos de argumentos não realizados fonologicamente. Fato este que corrobora inúmeros outros estudos os quais já apontaram este fato linguístico.

\subsection{A realização do OI lexical - uso de a x para}

Passemos à análise do tipo de preposição que encabeça o SP. Estudos sobre o PB atual apontam que, na língua falada e na língua escrita menos formal, há uma tendência em substituir a preposição $a$ pela preposição para com os verbos ditransitivos de transferência ou 
movimento (conf. Torres Morais, 2009). Por este motivo, na análise dos casos do uso de preposições $a$ e para como introdutores de $\mathrm{SN}$, ou seja, em que não há referência anafórica, esperávamos que os dados apontassem para predominância do pronome para em detrimento do $a$, mesmo em redações em que seria aferido o conhecimento linguístico do aluno. Os trechos abaixo ilustram esse uso.

(55) [ele $]_{\mathrm{N} 0}$ disse para o Normilsom ${ }_{\mathrm{N} 2}$ o seu irmão "cuida de tudo, agora tu e o hominho da casa".N1

(56) Desde a catástrofe, o imperador ${ }_{\mathrm{N} 0}$ ordenou aos seus súditos ${ }_{\mathrm{N} 2}$ que explorassem o infinito ${ }_{\mathrm{N} 1} \ldots$

As realizações de SN precedidos por $a$ e para mostraram-se ínfimas se confrontadas com os altos percentuais de realizações do OI nulo, ainda assim, em uma comparação entre as séries, os dados reforçam as conclusões de outros estudos: a queda no uso de $a$ e a preferência por para.

$\mathrm{Na}$ escola particular foram encontradas 13 ocorrências de $\mathrm{SN}$ precedido por preposição, sendo 10 realizados com para, ou seja, 76,92\%. Os maiores índices foram obtidos no $8^{\mathrm{a}}$ ano. Conforme tabela (24) abaixo.

Tabela 32 - Preenchimento de OI não anafórico realizado por SN precedido por preposição $a$ ou para divido por ano escolar na Escola Particular

\begin{tabular}{|c|c|c|c|c|c|c|c|}
\hline \multicolumn{2}{|c|}{$\sigma^{\circ}$ ano } & \multicolumn{2}{c|}{$7^{\circ}$ ano } & \multicolumn{2}{c|}{$8^{\text {o }}$ ano } & \multicolumn{2}{c|}{$9^{\circ}$ ano } \\
\hline A & PARA & A & PARA & A & PARA & A & PARA \\
\hline---- & 01 & 01 & 01 & 02 & 05 & ---- & 03 \\
\hline
\end{tabular}

Já na escola pública, foram encontradas 35 ocorrências de $\mathrm{SN}$ precedido por preposição, sendo 25 ocorrências com para (71,43\% dos dados). Diferentemente do ocorrido na escola particular, os maiores índices são observados no $7^{\circ}$ ano, 42,85\%. Ressalta-se, ainda, que no $9^{\circ}$ ano houve maior realização de $a$ do que para. Na subseção seguinte por meio das tipologias verbais buscamos justificar essa preferência. 
Tabela 33 - Preenchimento de OI não anafórico realização por SN precedido por preposição $a$ ou para - Escola Pública

\begin{tabular}{|c|c|c|c|c|c|c|c|}
\hline \multicolumn{2}{|c|}{$\boldsymbol{6}^{\boldsymbol{0}}$ ano } & \multicolumn{2}{c|}{$7^{\mathbf{0}}$ ano } & \multicolumn{2}{c|}{$8^{\boldsymbol{o}}$ ano } & \multicolumn{2}{c|}{$\mathbf{9}^{\boldsymbol{a}}$ ano } \\
\hline $\mathrm{A}$ & PARA & A & PARA & A & PARA & A & PARA \\
\hline 01 & 06 & 05 & 15 & --- & 03 & 04 & 01 \\
\hline
\end{tabular}

Equiparando-se os dados, o que se observa é um equilíbrio entre as porcentagens totais da escola pública e privada. Ou seja, mais uma vez, os dados comprovam que não há diferença entre o vernáculo do aluno da escola pública e da particular, em ambos o para é a estratégia utilizada no preenchimento do OI lexical. Como podemos observar nas ocorrências abaixo extraídas das duas instituições.

(57) E ouviu a conversa de Pedrita com ele, e viu que a Pedrita era má, e voltou para sua casa e [ela $]_{\mathrm{N} 0}$ falou para a carol ${ }_{\mathrm{N} 2}$ : Você é como uma irmã, te $\mathrm{amo}_{\mathrm{N} 1}$.

(58) Otávio ${ }_{\mathrm{N} 0}$ se aproximou e falou para o Luís ${ }_{\mathrm{N} 2}$, garoto temos que $\mathrm{ir}_{\mathrm{N} 1}$.

(59) Sem pensar mais um pouco, pegou o prato e $[\mathrm{ele}] \mathrm{N}_{0} \operatorname{deu}[\varnothing]_{\mathrm{N} 1}$ ao homem ${ }_{\mathrm{N} 2}$ faminto, que devorou os sanduiches.

- Ainda estou com muita fome!

(60) Lucas $_{\mathrm{N} 0}$ não conseguia dizer a Mariana o quanto a amava $a_{\mathrm{N} 1}$

Esse equilíbrio entre a escola pública e particular no que se refere a esse uso das preposições $a$ e para, pode ser mais bem observado no gráfico abaixo: 
Gráfico 15 - Preenchimento de OI não anafórico realizado por SN precedido por preposição $a$ ou para em verbos de transferência verbal e perceptual

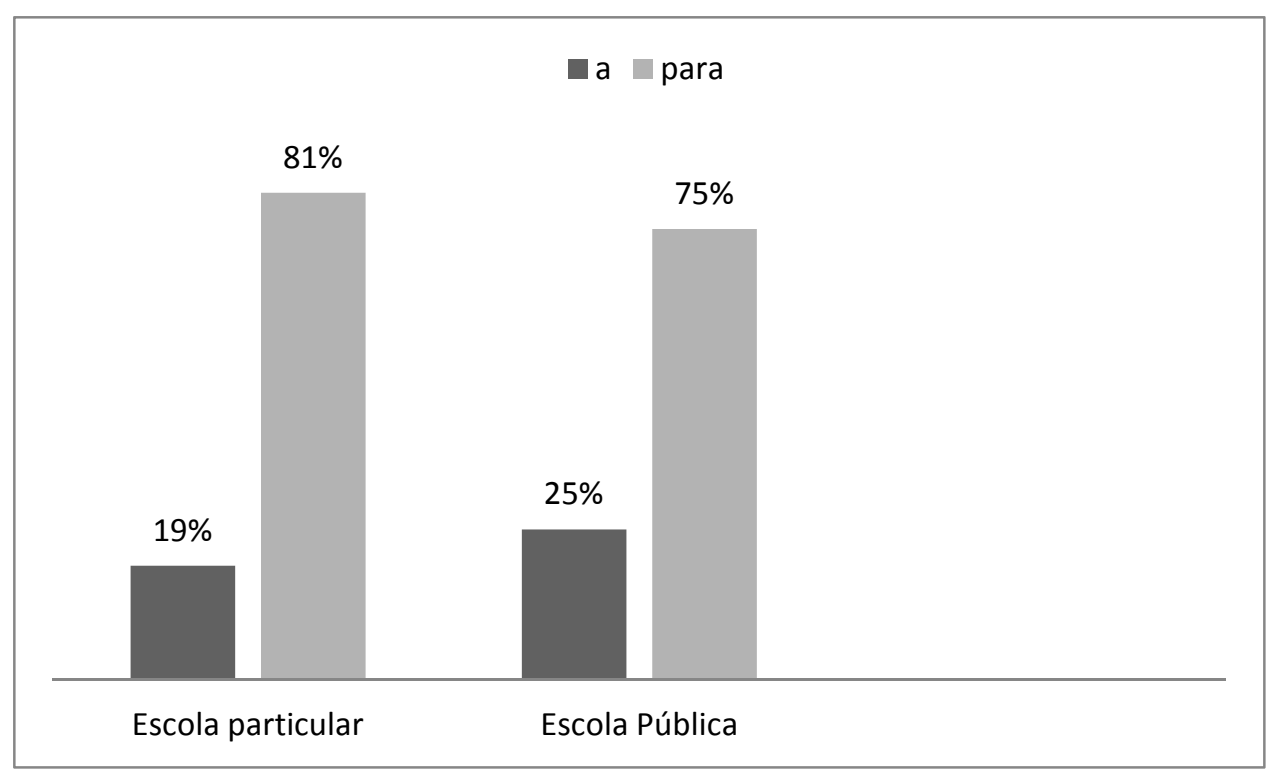

Nossos resultados relativos aos dados de língua escrita, para a escola pública e particular, revelam que o processo de substituição da preposição a por para, já consolidado na fala e comprovado por diferentes trabalhos, também se encontra bastante avançado no uso escrito e, além disso, mesmo dentro do ambiente escolar a preposição $a$ não é a estratégia preferida pelos alunos, apesar de ser considerada de prestígio.

Sabemos, por outro lado que o tipo verbal pode favorecer o uso de determinada preposição, por este motivo, nossa análise, a seguir, procurará observar a realização do OI por tipo de verbo, de acordo com a tipologia proposta por Berlinck (1996)

\subsubsection{Tipologia verbal na realização do OI lexical}

Em dados de língua falada (cf. Gomes, 2003), observa-se que a preposição para predomina, tanto como argumentos de um verbo de transferência material (dar), como em verbos de transferência verbal/perceptual (dizer)

Já em textos escritos de natureza semiformal, os estudos revelam que há um processo de variação. Torres Morais e Berlinck (2007) apontou que em contextos com verbos de transferência verbal e perceptual há predominância da preposição $a$ ( $82 \%$ das ocorrências) e que esse uso está direcionado ao grau de formalidade do texto. 
Acreditamos que a maior ou menor permeabilidade ao uso da preposição para em textos escritos deve estar vinculada à posição que cada texto ocupa em um continuum oralidade - letramento, do mesmo modo como Freire (2005) observou para o emprego do clítico dativo e do dativo nulo.

(Torres Morais e Berlinck, 2007, p. 65)

Sendo assim, na análise das ocorrências, um dos aspectos a considerar é o tipo de verbo ao qual o complemento se associa e, desta forma, aferir se tais usos vão ao encontro dos índices já levantados por outros estudos. Para tanto, restringimos nossa análise nas ocorrências com predicados dinâmicos construídos com verbos de atividade, também denominados verbos de transferência e verbos de movimento. (Berlinck, 1996)

No levantamento desses verbos nas redações, disposto na tabela (26), foram observadas apenas 13 ocorrências de OI lexical na escola particular. Desse total, mais de 50\% concentra-se no $8^{\circ}$ ano. Destaca-se, ainda, que 11 casos referem-se a verbos de transferência verbal e perceptual e não foram encontradas realizações com verbos de movimento.

Na escola pública, identificamos 35 ocorrências de OI lexical, porém a maior parte delas concentrada no $7^{\circ}$ ano, 20 casos. Assim como na escola particular, a maior concentração de ocorrências foi com os verbos de transferência verbal e perceptual, 24 e, novamente, não foram encontradas realizações com verbos de movimento.

Como percebemos, os dados apontaram a predominância absoluta de verbos de transferência verbal e perceptual, dicendi, em detrimento a outros. Novamente, ressaltamos o tipo de texto utilizado para justificar esse uso, especialmente em diálogos entre os personagens da história, assim sendo, torna-se necessário o uso de expressões tais como Ele disse, em que se empregam os verbos dicendi, observados nos exemplos abaixo:

(61) então [Mariana $]_{\mathrm{N} 0}$ perguntou para Lucas ${ }_{\mathrm{N} 2}$ que se ele ainda a a amava $\mathrm{N}_{\mathrm{N} 1}$

(62) ...quando acordou [ele $]_{\mathrm{N} 0}$ ficou falando para os médicos $\mathrm{N}_{2}$ que tinha visto o escritor. $_{\mathrm{N} 1}$

Nas ocorrências acima fica evidente a necessidade do autor em expressar as falas dos personagens por meio do uso dos verbos de transferência verbal iniciando o discurso indireto. 
Abaixo apresentamos o resultado específico das realizações de SP precedido por $a$ e para, divididas por ano escolar, na escola particular, tabela (34) e na escola pública, tabela (35)

Tabela 34 - Realização do OI lexical por série escolar na Escola Particular

\begin{tabular}{|l|c|c|c|c|c|c|c|c|}
\hline & \multicolumn{2}{|c|}{$\boldsymbol{6}^{\text {o }}$} & \multicolumn{2}{c|}{$7^{\text {o }}$} & \multicolumn{2}{c|}{$8^{\text {o }}$} & \multicolumn{2}{c|}{$9^{\text {o }}$} \\
\hline & $a$ & para & $a$ & para & $a$ & para & $a$ & para \\
\hline Transferência verbal e perceptual & --- & $100 \%$ & --- & $100 \%$ & $28,57 \%$ & $71,43 \%$ & --- & $100 \%$ \\
\hline Transferência material & --- & --- & $100 \%$ & --- & -- & --- & --- & $100 \%$ \\
\hline Movimento físico & --- & --- & --- & --- & --- & --- & --- & --- \\
\hline Movimento abstrato & --- & --- & --- & --- & --- & --- & --- & --- \\
\hline
\end{tabular}

Tabela 35 - Realização do OI lexical por série escolar na Escola Pública

\begin{tabular}{|l|c|c|c|c|c|c|c|c|}
\hline & \multicolumn{2}{|c|}{$\boldsymbol{\sigma}^{\text {o }}$} & \multicolumn{2}{c|}{$7^{\text {o }}$} & \multicolumn{2}{c|}{$8^{\text {o }}$} & \multicolumn{2}{c|}{$9^{\text {o }}$} \\
\hline & $\boldsymbol{a}$ & para & $\boldsymbol{a}$ & para & $\boldsymbol{a}$ & para & $\boldsymbol{a}$ & para \\
\hline Transferência verbal e perceptual & $14,28 \%$ & $85,72 \%$ & $28,57 \%$ & $71,43 \%$ & -- & $100 \%$ & $50 \%$ & $50 \%$ \\
\hline Transferência material & --- & --- & $16,67 \%$ & $83,33 \%$ & --- & $100 \%$ & $100 \%$ & ---- \\
\hline Movimento físico & --- & --- & --- & --- & --- & --- & --- & --- \\
\hline Movimento abstrato & --- & --- & --- & -- & -- & --- & --- & --- \\
\hline
\end{tabular}

Primeiro, podemos constatar preferência absoluta no uso de verbos de transferência verbal e perceptual realizados com para, tanto na escola particular como na escola pública, a porcentagem chega a $100 \%$ no $6^{\circ}, 7^{\circ}$ e $9^{\circ}$ ano da escola particular e no $8^{\circ}$ ano da escola pública. Em verbos de transferência material, identificamos realizações com $a$ e para. Especialmente no $9^{\circ}$ ano da escola pública, vamos identificar maior índice de $a$ nas realizações dos verbos de transferência material. Em ambas, ainda, observa-se a ausência de realizações de verbos de movimento.

$\mathrm{Na}$ porcentagens entre os dados gerais obtidos nas duas escolas, verificou-se a predominância absoluta de uso de para em todas as séries, com exceção do $9^{\circ}$ ano, conforme gráfico abaixo. 
Gráfico 16 - Uso de SN precedido de preposição $a$ ou para de acordo com a série escolar e o tipo de verbo

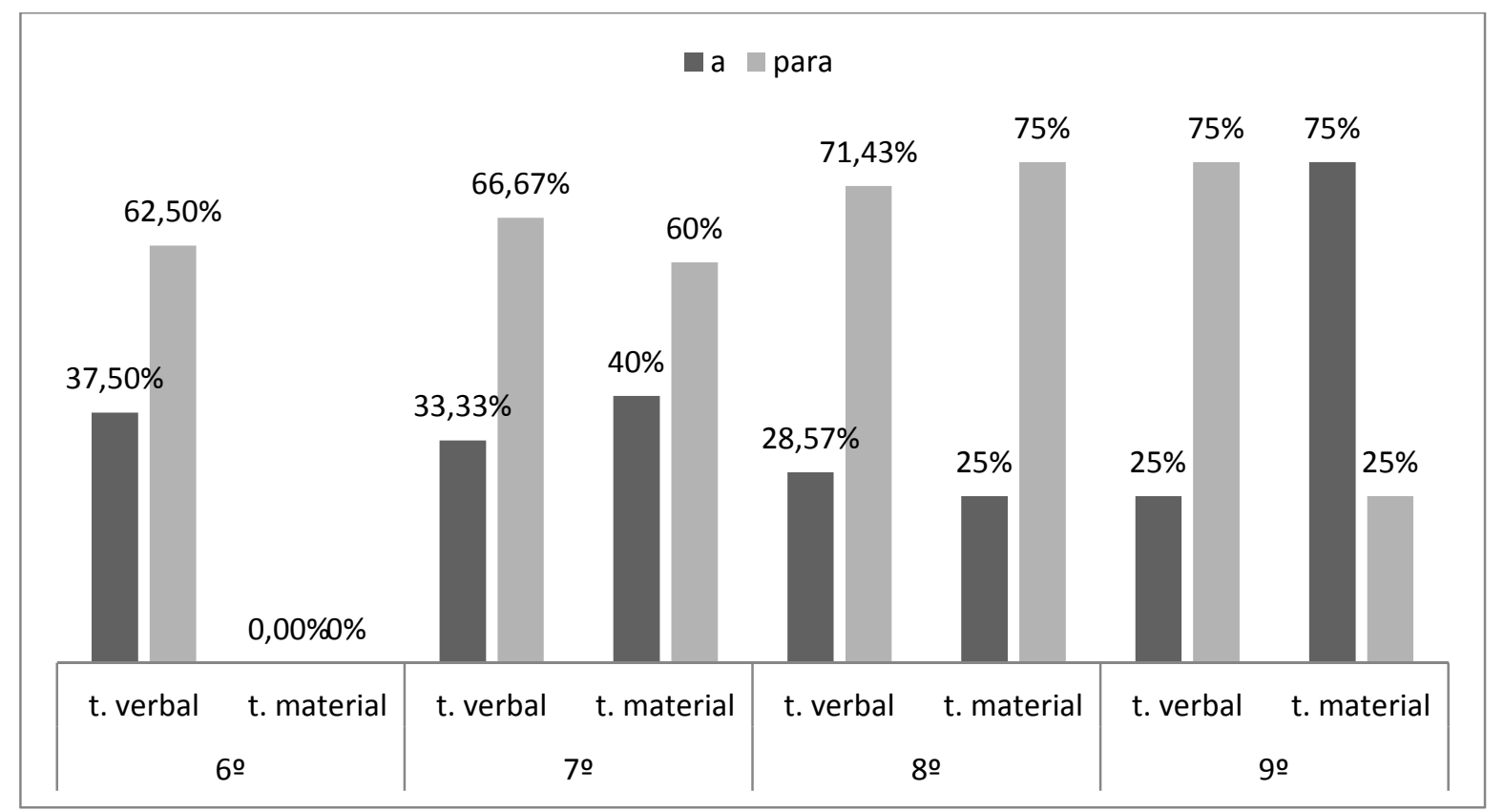

Podemos verificar a supremacia no uso de para em relação $a$ em todas as séries e nos dois tipos de verbos, transferência verbal e transferência material. A diferença percentual entre as realizações com uma ou outra preposição, mantem-se próxima em todas as séries. As realizações com para em verbos de transferência verbal crescem gradualmente de $62,50 \%$ no $6^{\circ}$ ano para $75 \%$ no $9^{\circ}$ ano.

Já com verbos de transferência material, há quadros distintos. Primeiro a não realização desse tipo de verbo no $6^{\circ}$ ano; em seguida, no $7^{\circ}$ e $8^{\circ}$ ano o quadro mostra-se similar aos usos com verbos de transferência verbal; por último, no $9^{\circ}$, o uso de $a$ suplanta o de para nesses verbos, $75 \%$ de realizações. Santos em sua já citada pesquisa com produções de alunos já identifica essa competição entre as preposições com o verbo dar, prototípico dos verbos de transferência material.

[Observamos] certa competição entre $a$ e para com o verbo dar. Essa competição não é observada com os demais verbos. Há de se ressaltar que se dar é de uso mais frequente na modalidade falada da língua, é ele que tem a função de verbo suporte (dar assistência, dar abrigo, dar apoio), contexto que, segundo Gomes (2003), favorece enormemente o emprego da preposição a, aliás, é o contexto de retenção dessa preposição.

(SANTOS, 2007, p.79) 
Podemos concluir que nas realizações de textos narrativos, como já dissemos, os alunos utilizam os verbos de transferência verbal em detrimento de outros verbos, para expressarem as falas dos personagens da narrativa. Nas realizações com OI lexical, a preposição $a$ foi substituída por para em todas as séries, exceto no $9^{\circ}$ ano, série em que a maior realização com verbos de transferência material favoreceu o uso de $a$.

No que concerne às diferenças entre as escolas, mais uma vez não identificamos diferenças na expressão vernacular dos alunos. O perfil linguístico desses falantes de ambas as instituições de ensino mostrou-se próximo ao que outros estudos já atestaram a respeito da realização lexical do OI precedido por preposição e pronominalizado por lhe/lhes de $3^{\mathrm{a}}$ pessoa. Ambas as estratégias são utilizadas unicamente em situações formais de uso e tais escolhas são oriundas da escolaridade, ou seja, trata-se de uma questão de uso de regras estilísticas pertencentes ao comportamento linguístico.

\subsection{Os textos}

$\mathrm{Na}$ análise das ocorrências, foi possível observar as redações como um todo e, assim verificar as diferenças textuais presentes. Apesar dessa elaboração dos textos não ser o principal foco deste trabalho, as variantes encontradas principalmente nas produções dos alunos da escola pública, reforçam a teoria de que há um vernáculo bastante similar entre as crianças no que se refere às mudanças apontadas sobre a realização do OI, mas, por outro lado, há variantes bastante específicas ao aluno da escola pública.

Ao longo do Ensino Fundamental verifica-se uma melhora na qualidade dos textos, no que compete à coesão, construção textual, concordância e ortografia, mas ainda é possível perceber a dificuldade na construção da narrativa, como no exemplo abaixo:

(63) Certa vez enquanto caminhava e via a grande movimentação da cidade, já estava ficando estressado, com toda essa correria. Minha esposa já está pensando em se mudar, para um lugar mais tranquilo sair da grande movimentação.

Dentre as variantes encontradas destacamos as mais evidentes nos textos, entre elas as que se referem a:

\section{(i) Ortografia}


(64) Um serto dia eles foram Para a escola Primeiro dia de aula Douglas falou

- Eu estou entuziasmado Primeiro dia de aula do ano foram para casa e ai 30 anos se passarão...

(65) A Patricia 17 anos e morrava em Florianopuli com os seus pais

(ii) Concordância verbal

(66) ...mas Lucas dizer que não era para dar o endereço para ela.

(E8-02)

\section{(iii) Concordância nominal}

(67) Lucas não sabia o que dizer a ele, via predios cinzento, ruas cinzenta e céu cinzento.

\section{(iv) Colocação pronominal}

(68) Se passaram, nove anos quando ele foi para a faculdade...

\section{(v) Elementos de coesão textual}

(69) ...Jack e Herry eram muito amigos, todos estranharam a amizade deles, porque eles eram as pessoas mais felizes da escola mesmo que a professora batesse em um o outro defendi o outro...

Se na realização dos OI de $3^{\text {a }}$ pessoa não foram identificadas disparidade entre os dados, na elaboração do texto há divergências acentuadas. Não identificamos entre os alunos da escola particular, índices acentuados de variantes referentes à ortografia e concordância verbal. Já na escola pública, tais variantes foram mais comuns. Por outro lado, o que destacamos é a pouca produtividade dos alunos de $9^{\circ}$ ano da escola pública. A maioria dos textos não apresentava mais do que 15 linhas e não obedeciam aos padrões elementares de construção textual: unidade, coesão e coerência. 
Ou seja, se as diferenças socioeconômicas não interferem no vernáculo do aluno, estas se evidenciam na elaboração da lógica do pensamento por meio da linguagem escrita. 


\section{Conclusão}

Este trabalho se propôs a investigar as realizações de OI em contextos de verbos bitransitivos durante o processo de letramento de alunos do EF2, em duas situações sociais distintas, na escola pública e na escola particular.

Buscamos o ambiente escolar, pois inúmeros estudos já atestaram as variações consolidadas na fala e na escrita do falante culto do PB. Importava-nos o comportamento dessas variantes durante a fase de letramento, especialmente nas séries finais do EF2 em que o aluno passa a ter, nas aulas de português, o conhecimento normativo da organização sentencial de sua língua materna. É nesse período que o falante começa a perceber intuitivamente que há uma língua que ele adquiriu, a qual não parece com aquela que ele aprende na escola, devido a esta valorizar as formas de prestígio em detrimento das variantes adquiridas na fase de aquisição.

Na observância dos textos produzidos por alunos tivemos em mão uma atividade com características bem distintas, primeira, ao propor um tipo narrativo almejávamos alcançar nas redações uma expressão mais marcante do vernáculo, entendido como a língua falada, sem monitoramento. Por outro lado, não pudemos deixar de ponderar que a produção de texto, por seu caráter avaliativo, seria o momento de exposição das formas consideradas de prestígio pela escola, embora estas estejam distantes da gramática internalizada do aluno. O que se observa normalmente é que o aluno utiliza essa língua mais monitorada em trechos específicos, mas, geralmente, retoma sua gramática internalizada, ou seja, o vernáculo.

Com relação ao OI anafórico, os dados corroboraram outros vários estudos, os quais apontaram como estratégia preferida dos falantes o OI nulo. Essa variante, na escola pública, foi de tal forma superior às demais, que os índices em todas as séries foram maiores de 70\%, chegando a $90 \%$ no $8^{\circ}$ ano. Por outro lado, a forma de prestígio, o clítico dativo de $3^{\text {a }}$ pessoa, só foi produzido no $7^{\circ}$ ano, representando apenas $11,94 \%$ da totalidade de ocorrências desta série. Além disso, observou-se que, metade dessas ocorrências foram produzidas pelo mesmo falante, fato este que, para nós, pode estar associado a um estilo linguístico e não gramatical, como apontam Kato, Cyrino e Correia (2009). A terceira variante, preposição+pronome, obteve percentual entre 10 e $20 \%$, mostrando-se como ainda menos produtiva, se comparada ao OI nulo, porém mais produtiva do que o clítico.

$\mathrm{Na}$ escola particular, os resultados foram ainda mais marcantes tanto nas realizações com OI nulo quanto com a forma clítica. O OI nulo alcançou índices superiores a 80\%, 
chegando a $96 \%$ no $8^{\circ}$ ano, enquanto o clítico não foi realizado nenhuma vez em todas as séries. A variante preposição+pronome foi a realização do OI entre 4 e $10 \%$ das ocorrências.

Esses altos índices de OI nulo são interessantes porque, de alguma forma, revelam que o clítico não foi adquirido e, no caso específico do OI, as variantes que substituem essa estratégia não são consideradas erradas pela escola. Ou seja, em relação às duas estratégias mais produtivas, particularmente o OI nulo, não há propriamente um estigma, uma rejeição em termos de padrões de correção. O mesmo pode-se dizer a respeito das formas preposicionais (para ele(s)/para ela(s)/ a ele(s)/a ela $(s)$ ), ao contrário do objeto direto que, quando é realizado por essas formas $(e l e(s) / e l a(s))$, recebe a baixa avaliação, condicionada pela oposição norma padrão vs. norma não padrão. O professor, por não "corrigir" essas realizações nulas, inserindo o clítico (lhe), acaba anulando a avaliação negativa da variante.

$\mathrm{Na}$ descrição dos usos do OI anafórico de acordo com a tipologia verbal, novamente os dados reforçaram o que pesquisas anteriores já atestaram, a supremacia no uso de OI nulo como realização dos verbos de transferência verbal e perceptual. Esse seria, na verdade, outra particularidade do OI nulo. Diferentemente do OD nulo, o OI engloba os verbos dicendi, denominados por Berlinck (1996) como verbos de transferência verbal. Ora, como se sabe, com este tipo de verbo é comum o apagamento do OI, mesmo em línguas que não permitem o OI nulo em sua gramática nuclear.

Assim, as realizações com OI nulo, nesses tipos de verbos, chegou a $100 \%$ no $8^{\circ}$ ano da Escola Particular e no $9^{\circ}$ ano da Escola Pública, sendo o índice mais baixo o de 70,60\% no $9^{\circ}$ ano da escola particular.

Outro ponto refere-se ao uso da preposição $a$ e para na introdução do OI. Foram identificados poucos casos na produção dos alunos da escola particular, apenas 13. Sendo 03 preenchidos com $a$. Já nas redações coletadas na escola pública houve 35 casos, e, novamente com preferência de para em detrimento de $a$. No entanto, diferentemente da escola particular em que essa supremacia ocorreu em todas as séries, na escola pública os casos de $a$ suplantaram o de para no $9^{\circ}$ ano. A suposição por nós levantada é que tal fato relaciona-se com o tipo de verbo mais produtivo no $9^{\circ}$ ano, os verbos de transferência material. Em todas as outras séries, houve predominância de verbos de transferência verbal e perceptual.

De maneira geral, o que observamos nos dados é que o aluno, em fase de aprendizado, não utiliza como estratégia de realização do OI aquelas reiteradamente expostas nos compêndios normativos: clítico dativo e lexical, precedido pela preposição $a$. Para o falante do PB, o OI, no contexto dos verbos bitransitivos, é um argumento que pode ser realizado por 
uma forma nula fonologicamente, ou por pronome antecedido por preposição a/para, nas realizações anafóricas e lexicais. Somente em contextos formais o clítico dativo é produtivo.

Assim, como esse trabalho confrontou duas escolas com perfis econômicos distintos, esperávamos que fatores de ordem social e intelectual poderiam ter levado as crianças a uma competência linguística acrescida de uma periferia estilística, adquirida em uma maior exposição a leituras e experiências mais ricas e variadas, já iniciada em fase pré-escolar. Em ambas as instituições, porém, os cenários encontrados foram muito próximos e não houve um só caso em que os alunos da escola particular, por teoricamente estarem inseridos em ambientes do tipo acima mencionados, reproduzissem com maior precisão as formas de prestígio.

Finalmente, como abordamos questões referentes ao ensino da língua portuguesa dentro das escolas, esperamos, com esse trabalho, contribuir para uma efetiva mudança no paradigma do ensino do $\mathrm{PB}$, que entre a banalização do ensino da gramática e a falta de domínio do campo da linguística, desenvolve, em sala de aula, práticas retrógradas que incutem no aluno a velha imagem de que Língua Portuguesa é difícil, e de que o Português da escola é efetivamente uma língua a ser aprendida.

Neste contexto, o jovem, portanto, não pode reconhecer que a sua competência na língua materna é algo que lhe pertence desde os primeiros momentos de aquisição, sendo portanto um falante que a domina completamente. 


\section{Referências Bibliográficas}

ARMELIN, Paula R. G. Sentenças bitransitivas do português do Brasil revisitadas à luz da teoria dos núcleos aplicativos. Dissertação de Mestrado. Universidade de São Paulo, 2011.

AVERBUG, Mayra Cristina Guimarães. Objeto direto anafórico e sujeito pronominal na escrita de estudantes. Dissertação de Mestrado. Rio de Janeiro: UFRJ/FL, 2000.

Objeto direto anafórico e sujeito pronominal na escrita de estudantes, 2003. Disponível em < http://www.filologia.org.br/viicnlf/anais/caderno11-12.html >. Acesso em: 23 de abril, 2013.

Objeto direto anafórico: variação na produção oral e escrita e influência do ensino. Estudos da linguagem: atualidade \& paradoxos; Anais do VII Congresso da ASSEL-RIO. Rio de Janeiro: ASSEL-RIO, 1998. p. 680-687.

BECHARA, Evanildo. Moderna gramática portuguesa. $37^{\text {a }}$ ed. Rio de Janeiro: Nova Fronteira/Lucerna, 2009.

BENVENUTTI, Ana Maria Zys. O Pronome objeto no PE e PE: um estudo sincrônico. Dissertação de mestrado. Londrina: UEL, 2002.

BERLINCK, Rosane de Andrade. O objeto indireto no português brasileiro: um estudo diacrônico. In: Rosane de Andrade BERLINCK; Gladis Massini CAGLIARI; Marymarcia GUEDES; Clotilde de Almeida Azevedo MURAKAWA. (Org.). Estudos de Linguística Histórica do Português. $1^{a}$ ed. Araraquara. São Paulo: Laboratório Editorial FCL/UNESP / Cultura Acadêmica, 2005, v. 1, p. 123-139.

Dativo ou Locativo? Sobre sentidos e formas do "dativo" no português. Curitiba. Revista Letras, 2001. n. 56, pp.159-175.

The Portuguese Dative. In: VAN BELLE, W \& VAN LANGENDONCK, W. The Dative. Amsterdam: John Benjamins, 1996. (Descriptive Studies, 1). p. 119-151.

Sobre a realização do objeto indireto no português do Brasil. In: II Encontro do CelSul (CÍRCULO DE ESTUDOS LINGÜÍSTICOS DO SUL). Anais. Florianópolis: UFSC, 1997. 
; DUARTE, Maria Eugênia Lamoglia; OLIVEIRA, Marilza de. Predicação. In: Mary Kato e Milton do Nascimento (Orgs.). Gramática do português culto falado no Brasil: a construção da sentença. Vol. III. Campinas: Editora da Unicamp, 2009. pp. 101-188.

BISPO, Karla Cristina Iseke. A sintaxe do objeto indireto no português do Brasil. Brasília, DF: Universidade de Brasília, Dissertação de Mestrado, 2004.

CÂMARA JUNIOR, J. Mattoso. Dicionário de linguística e gramática. $18^{\mathrm{a}}$ ed. Petrópolis: Vozes, 2002.

CAMPOS, Ednalvo Apóstolo. O dativo de terceira pessoa no português culto falado em Belém. Dissertação de Mestrado. FFLCH-USP, 2010.

CASTILHO, Ataliba T. de. Gramática do Português Brasileiro. 1ª ed. São Paulo: Contexto, 2010.

CHOMSKY, N. Lectures on government and binding. Dordrecht: Foris, 1981.

N. Knowledge of languages. New York: Praeger, 1986.

Language and Problems of Knowledge - The Managua Lectures. Cambridge: MIT Press, 1988.

CYRINO, S., NUNES, J. PAGOTTO, E. Complementação. In Gramática do português culto falado no Brasil - A construção da sentença, orgs. M. A Kato, M. do Nascimento. Campinas: Editora da UNICAMP, 2009. Cap. 2.

CORRÊA, Vilma Reche. Objeto direto nulo no português do Brasil. Dissertação de Mestrado. Campinas: UNICAMP, 1991.

CUNHA, Celso \& CINTRA, Lindley. Nova Gramática do Português Contemporâneo. 2a . ed. Rio de Janeiro: Nova Fronteira, 1985.

DUARTE, M. Eugênia Lamoglia. Variação e sintaxe: clítico acusativo, pronome lexical e categoria vazia no português do Brasil. Dissertação de mestrado. São Paulo, PUCSP, 1986. 
Do pronome nulo ao pronome pleno: a trajetória do sujeito no português brasileiro. In: ROBERTS, IAN \& KATO, MARY A.. (Org.). PORTUGUÊS BRASILEIRO: UMA VIAGEM DIACRÔNICA. CAMPINAS, SP: ED. DA UNICAMP, 1993, v. , p. 107-128.

A perda do princípio "Evite Pronome" no português brasileiro. Tese de doutorado, Campinas: Unicamp, 1995

. Sujeitos de referência definida e arbitrária: aspectos conservadores e inovadores na escrita padrão. Linguística (PPGL/UFRJ), v. 3, p. 89-115, 2007.

DUTRA, Lívia Romero. O clítico acusativo na redação escolar. Dissertação de Mestrado. Universidade Federal do Rio Grande do Sul, 2003

FREIRE, Gilson C. Os clíticos de terceira pessoa e as estratégias para sua substituição na fala culta brasileira e lusitana, 2000. Dissertação de Mestrado. Universidade Federal do Rio de Janeiro, 2000.

A realização do acusativo e do dativo anafóricos de terceira pessoa na escrita brasileira e lusitana. Tese de doutorado - Universidade Federal do Rio de Janeiro. Rio de Janeiro, 2005.

Considerações sobre o ensino de clíticos. Anais do SIELP. Volume 1, Número 1. Uberlândia: EDUFU, 2011. Disponível em <http://www.ileel.ufu.br/anaisdosielp/pt/arquivos/sielp2011/artigo_34.pdf > Acesso em 25 de abril, 2013.

GALVES, C. A gramática do português brasileiro. Línguas \& Instrumentos Linguísticos. n.1, 1998. p.79-93.

GOMES, Christina A. Aquisição e perda de preposição no português do Brasil. Rio de Janeiro, UFRJ, tese de doutorado, 1996.

Variação e mudança na expressão do dativo no Português Brasileiro. In Paiva/Duarte (eds.) Mudança linguística em tempo real. Rio de Janeiro, Livraria/Faperj, 2003.

INVESTSANTOS. Disponível em < http://www.investsantos.com.br/>. Acesso em 25 de Abril, 2013 
KATO, M.A. . A gramática do letrado: questões para a teoria gramatical. In: M.A.Marques, E.Koller; J.Teixeira \& A.S.Lemos. (Org.). Ciências da Linguagem: 30 anos de investigação e ensino. Braga: CEHUM (Universidade do Minho), 2005, p. 131-145.

; CYRINO, S. ; CORREA, V. R. . Brazilian Portuguese and the recovery of lost clitics through schooling. In: A. Pires e J. Rothman. (Org.). Minimalist Inquiries into Child and Adult Language Acquisition: Case Studies across Portuguese. Haia: Mouton, 2009, v. , p. 245-272.

LDB. Lei de Diretrizes e Bases da Educação. Disponível em <http://portal.mec.gov.br/arquivos/pdf/ldb.pdf〉. Acesso em 25 de Abril, 2013.

LOPES, R. E. V.. The Production of Subject in Brazilian Portuguese by a Young Child. PROBUS 15, 2003. 123-146.

MAGAlHÃES, Telma M. Viana. O Sistema Pronominal Sujeito e Objeto na Aquisição do Português Europeu e do Português Brasileiro. Tese de Doutorado. Universidade Estadual de Campinas, 2006.

MARCUSCHI, Luiz Antônio. Produção Textual, Análise de Gêneros e Compreensão. São Paulo: Parábola, 2008

MATEUS, Maria Helena Mira et al. Gramática da Língua Portuguesa. 5a. ed. Lisboa: Editora Caminho, 2003.

MORETTI, Fabiana Cristina Baldim Lopes. Os Verbos de Transferência/Movimento no PB $e$ a Expressão do Objeto Indireto - Revisitando a Noção de Estrutura Argumental à Luz da Morfologia Distribuída. Dissertação de Mestrado. USP, 2010

OLIVEIRA, Marilza de. A perda da preposição a e a recategorização de lhe. Gel -2003. Disponível em: <http://www.fflch.usp.br/dlcv/lport/pdf/maril008.pdf>. Acesso em 25 de Abril, 2013.

PAREDES SILVA, Vera Lúcia. Cartas cariocas. A variação do sujeito na escrita informal. Tese de Doutorado. UFRJ, 1988.

PCN. Parâmetros Curriculares Nacionais. Disponível em <http://portal.mec.gov.br/seb/arquivos/pdf/livro01.pdf>. Acesso em 25 de Abril, 2013 
PLANO ESCOLAR DO LICEU SANTISTA. Santos, 2011.

PROJETO POLÍTICO PEDAGÓGICO UME EDMÉA LADEVIG. Santos, 2011.

RAMOS, C.M.A. O clítico de terceira pessoa: um estudo comparativo português brasileirolespanhol peninsular. Tese de Doutorado. Universidade Federal de Alagoas, 1999.

ROCHA LIMA, C. H. da. Gramática Normativa da Língua Portuguesa. 46 ${ }^{\mathrm{a}}$ ed. Rio de Janeiro: José Olímpio Editora, 2007.

RODRIGUES, M. L. ; LÚZIO, E. R. C. . Marcas da Oralidade em Textos Escritos. WebRevista Página de Debate: questões de linguística e de linguagem, v. 01, p. 01-24, 2009.

SANTOS, Luís Eduardo dos. A realização do objeto indireto anafórico, uma questão de aprendizagem. Dissertação de Mestrado. USP, 2007

SILVEIRA, Gessilene. A realização variável do objeto indireto (dativo) na fala de Florianópolis. Letras de Hoje, Porto Alegre, v. 35, n. ${ }^{\circ}$ 1, p. 189-207, 2000.

SIMÕES, L. Sujeito Nulo na Aquisição do Português Brasileiro: um estudo de caso. Tese de Doutorado. Porto Alegre: PUCRS, 1997.

- Sujeito Nulo na Aquisição do Português do Brasil. Cadernos de Estudos Linguísticos (UNICAMP), Campinas, v. 36, p. 105-130, 1999.

TORRES MORAIS, M. A. C. R.; BERLINCK, Rosane de Andrade. A caracterização do objeto indireto no português: aspectos sincrônicos e diacrônicos. In: Tânia Lobo; Ilza Ribeiro; Zenaide Carneiro; Norma Almeida. (Org.). Para a história do português brasileiro: novos dados, novas análises. Salvador: EDUFBA, 2006. v. 6, pp. 73-106.

; BERLICK, Rosane de Andrade. "Eu disse pra ele" ou "Disse-lhe a ele": a expressão do dativo nas variedades brasileira e européia do português. In CASTILHO, A. T. et alii (Org.) Descrição, História e Aquisição do Português Brasileiro. São Paulo: Fapesp, Campinas: Pontes Editores, 2007. p. 61 a 83.

; BERLINCK, Rosane de Andrade . Em busca do português paulista. In: Maria Aparecida C.R. Torres Morais \& Maria Lúcia da C.V.de O. Andrade. (Org.). História do Português Paulista- Série estudos Vol II. 1 ed. Campinas: IEL Publicações, 2009, v. vol II, p. 217-248. 
; SALLES, H. M. . Parametric change in the grammatical encoding of indirect objects in Brazilian Portuguese. Probus (Dordrecht), v. 22, p. 181-209, 2010.

\& RIBEIRO, Ilza. Contraste da sintaxe dos clíticos no português europeu e português brasileiro. Linha Dégua. n 17. São Paulo: Humanitas, 2005. p. 21-48. 


\section{ANEXOS}

Anexo 1 - Unidade Municipal de Ensino Edméa Ladevig

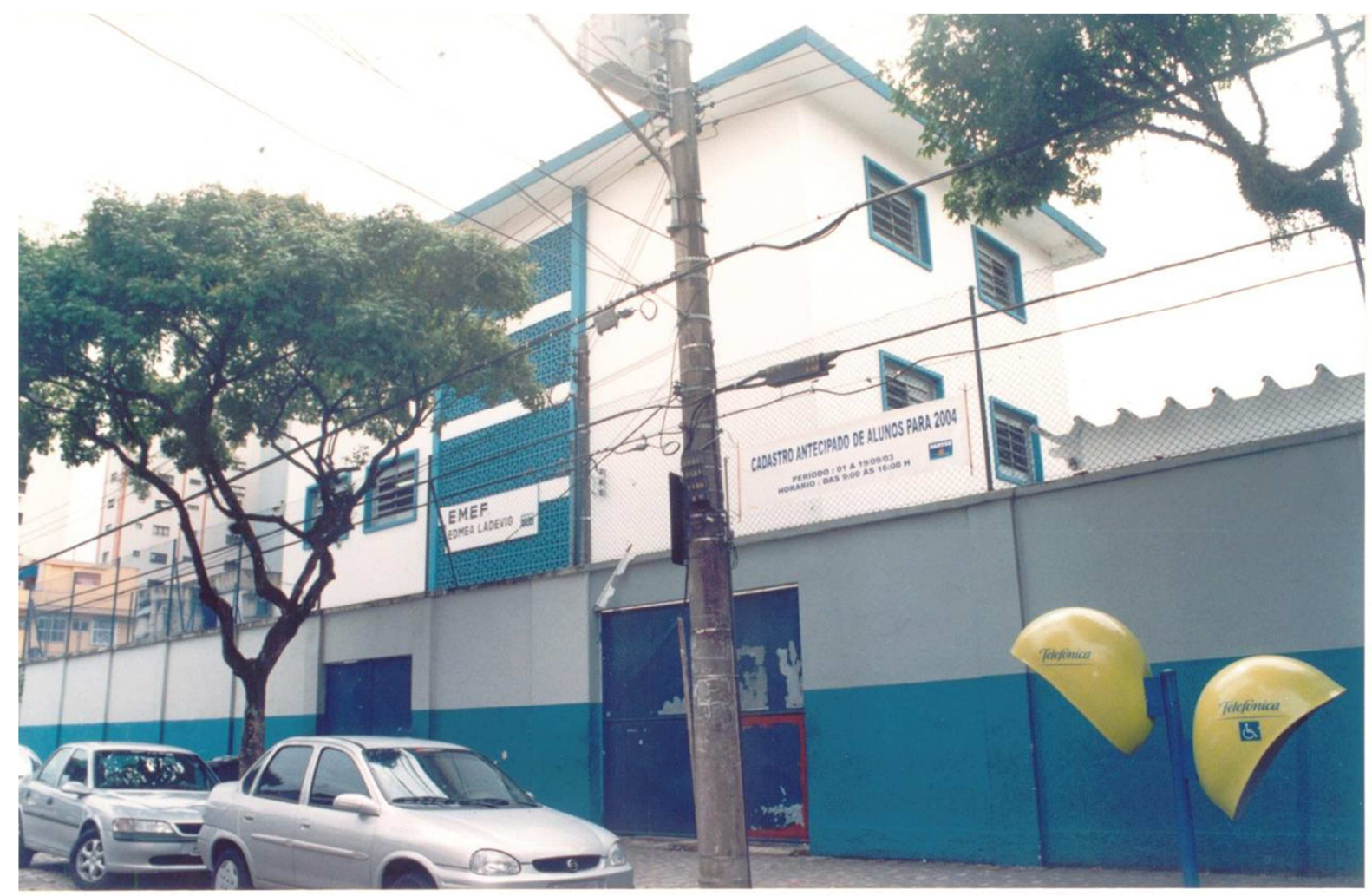

http://construtor.aprendebrasil.com.br/ui/50440001/2141520/t11_Foto.JPG

Anexo 2 - Liceu Santista

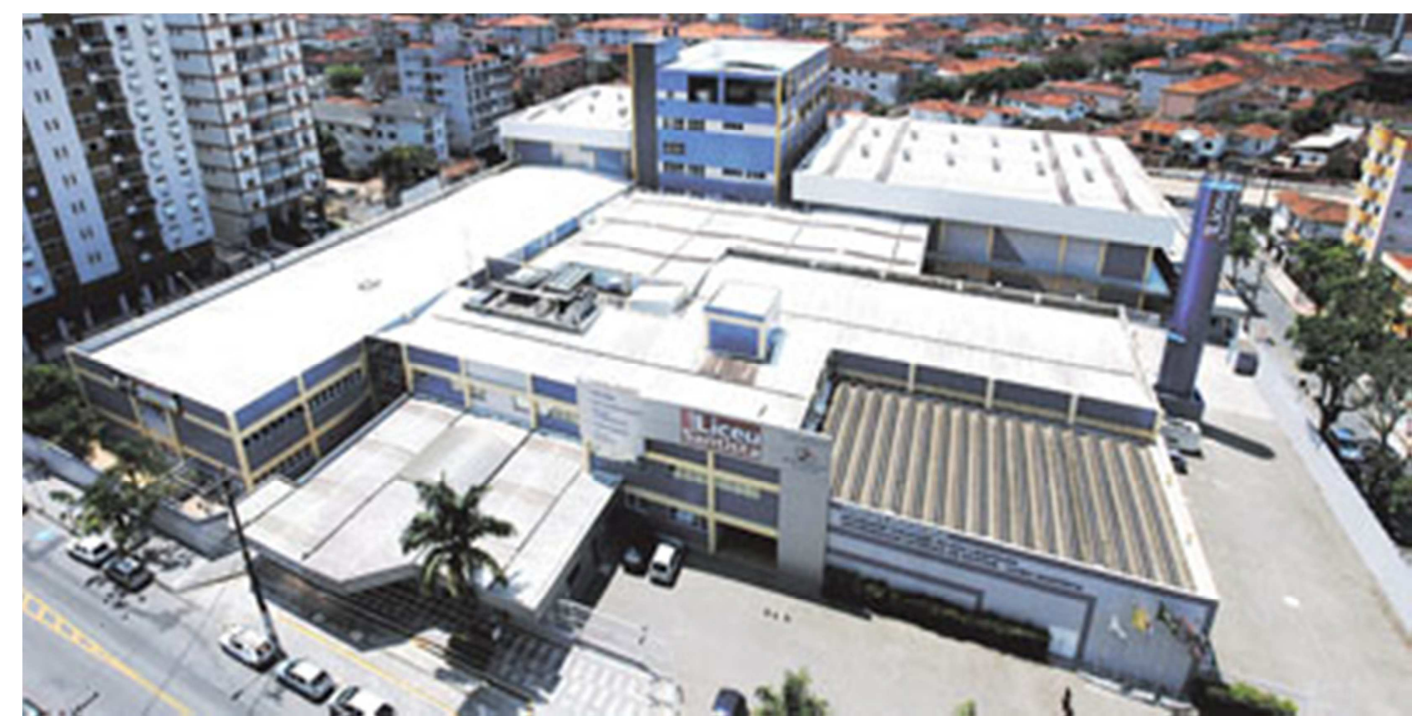

http://www.liceusantista.com.br/web/guest/12 
Anexo 3 - Ocorrências

\section{$6^{0}$ ano - Escola Particular}

\section{$\underline{\text { Redação } 1}$}

(01) Seu amigo pensou que João estava com raiva dele e [Seu amigo $]_{\mathrm{N} 0}$ falou para ele ${ }_{\mathrm{N} 2}$ no msn:

- Não sou mais seu amigo ${ }_{\mathrm{N} 1}$.

\section{$\underline{\text { Redação } 2}$}

(02) ...Jack era o melhor também na faculdade, mas ele era tão bom que [eles $]_{\mathrm{N} 0}$ ofereceram uma vaga ${ }_{\mathrm{N} 1}$ para ele $_{\mathrm{N} 2}$ na faculdade na Inglaterra

(03) Se passou uma semana e ele recebeu uma carta dizendo que Jack estava vivo mas com dores. Herry ${ }_{\mathrm{N} 0}$ pediu $[\theta]_{\mathrm{N} 2}$ o helicoptero imprestado $\mathrm{N}_{\mathrm{N} 1}$ e foi para a Inglaterra.

\section{$\underline{\text { Redação } 3}$}

(04) Depois eles notaram o cara e [eles $]_{\mathrm{N} 0}$ perguntaram $[\theta]_{\mathrm{N} 2}$ : - da onde você é ${ }_{\mathrm{N} 1}$ Você é do Haiti? Etc.

(05) $\operatorname{Over}_{\mathrm{N} 0}$ não respondeu $[\theta]_{\mathrm{N} 2} \operatorname{nada}_{\mathrm{N} 1}$

(06) ...ele $\mathrm{N}_{\mathrm{N} 0}$ só falou $[\theta]_{\mathrm{N} 2}$ : - a dimensão tem poder e o poder não tem dimensão.N1

(07) ...e eles saltaram e pousaram na cidade deles e $[\text { eles }]_{\mathrm{N} 0}$ falaram $[\theta]_{\mathrm{N} 2}$ : "-Doces ou travessuras" ${ }_{\mathrm{N} 1}$ cara pode crer.

\section{$\underline{\text { Redacão } 4}$}

(08) Na hora do almoço $[\text { elas }]_{\mathrm{N} 0}$ pediram $[\theta]_{\mathrm{N} 2}$ silencio $_{\mathrm{N} 1} \ldots$ 
(09) ...e todas juntas $_{\mathrm{N} 0}$ pediram $[\theta]_{\mathrm{N} 2}$ desculpas $_{\mathrm{N} 1}$ :

(10) - Gabrielle nos desculpe, nós nos sentimos muito tristes por te magoar e por desapontar os garotos $\operatorname{N} 1-\operatorname{disseram}[\theta]_{\mathrm{N} 2}$ todas as meninas ${ }_{\mathrm{N} 0}$.

(11) - Eu desculpo ${ }_{\mathrm{N} 1}$ - disse $[\theta]_{\mathrm{N} 2}$ Gabrielle $_{\mathrm{N} 0}$ abraçando as meninas emocionada

\section{$\underline{\text { Redação } 5}$}

(12) Clara foi até lá, com aqueles olhos castanhos e [ela $]_{\mathrm{N} 0}$ perguntou $[\theta]_{\mathrm{N} 2}$ :

- Posso brincar com você? 1

(13) $\quad-$ Pode $_{\mathrm{N} 1}$

Respondeu $[\theta]_{\mathrm{N} 2}$ ela $\mathrm{N}_{\mathrm{N} 0}$ com um sorriso tímido no rosto.

(14) Ela foi em direção das duas, com um andar metido e falou

- O que as duas mediocres estão fazendo no meu jardim

- O jardim não é seu, deixa agente em paz.N1

Respondeu $[\theta]_{\mathrm{N} 2}$ Clara $_{\mathrm{N} 0}$ firme:

(15) Clara não sabia o nome da menina e [ela $]_{\mathrm{N} 0}$ perguntou $[\theta]_{\mathrm{N} 2}$

- Qual é seu nome? $?_{\mathrm{N} 1}$

(16) - Que nome bonito! 1

Disse $[\theta]_{\mathrm{N} 2}$ Clara $_{\mathrm{N} 0}$ com um sorriso no rosto

(17) - É sério.N1

Respondeu $[\theta]_{\mathrm{N} 2}$ Clarissa $_{\mathrm{N} 0}$ feliz..

\section{Redaç̃o 6}

(18) Chegou perto e $[\text { ela }]_{\mathrm{N} 0}$ disse $[\theta]_{\mathrm{N} 2}$ :

- Oi, tudo bem? Qual o seu nome? 1 
(19) Laura $_{\mathrm{N} 0}$ disse $[\theta]_{\mathrm{N} 2}$ :

- Oi meu nome é Laura 1

(20) Peneloupe $\mathrm{N}_{\mathrm{N} 0} \operatorname{diz}[\theta]_{\mathrm{N} 2}$

- Oi o meu é Peneloupe 1

\section{$\underline{\text { Redação } 7}$}

(21) Um (dia) Vitória falto e Luciana $\mathrm{N}_{\mathrm{N} 0}$ pedio $[\theta]_{\mathrm{N} 1}$ desculpas $_{\mathrm{N} 2}$

\section{$\underline{\text { Redação } 8}$}

Não há

\section{Redaç̃o 9}

(22) ...derrepente João chega e [João $]_{\mathrm{N} 0}$ fala $[\theta]_{\mathrm{N} 2}$ "Jack eu vou te dizer uma cois, mas não sei se vai gostar! $!_{\mathrm{N} 1}$

(23) Seu amigo André está te traindo!!! e Jack $_{\mathrm{N} 0}$ fala $[\theta]_{\mathrm{N} 2}$ "é mentira ele nunca fará isso" ${ }_{\mathrm{N} 1}$

(24) ...depois de alguns dias teve uma briga com Jack e André nisso em briga André ${ }_{\mathrm{N} 0}$ fala $[\theta]_{\mathrm{N} 2}$ "É nunca gostei de você!"” ${ }_{\mathrm{N} 1}$ nisso acabou Jack nunca mais falou com André e João se tornou-se os melhores amigos.

\section{$\underline{\text { Redação } 10}$}

(25) ...cadê o passarinho e carolina começou a chorar e [ela $]_{\mathrm{N} 0}$ contou $[\theta]_{\mathrm{N} 2} \operatorname{tudo}_{\mathrm{N} 1}-$ mais manuela achou que ela estava a enganando...

(26) E começou a ouvir um pi pi pi e $[\mathrm{ela}]_{\mathrm{N} 0}$ falou $[\theta]_{\mathrm{N} 2}$ : O chuchu (passarinho) $)_{\mathrm{N} 1}$.

(27) E ouviu a conversa de Pedrita com ele, e viu que a Pedrita era má, e voltou para sua casa e [ela $]_{\mathrm{N} 0}$ falou para a carol ${ }_{\mathrm{N} 2}$ : Você é como uma irmã, te amo $_{\mathrm{N} 1}$. 


\section{$6^{0}$ ano - Escola Pública}

\section{$\underline{\text { Redacão 01 }}$}

(28) No meio do caminho Luís ${ }_{\mathrm{N} 0}$ pensou e disse ao motorista ${ }_{\mathrm{N} 2}$ ir mais devagar ${ }_{\mathrm{N} 1} \ldots$

(29) Desesperado no que $[\theta]_{\mathrm{N} 0}$ falar $[\theta]_{\mathrm{N} 1}$ ao taxista ${ }_{\mathrm{N} 2}$ parando o carro...

(30) Luís ${ }_{\mathrm{N} 0}$ teve a ideia de falar $[\theta]_{\mathrm{N} 2}$ que estava fazendo uma pesquisa da escola ${ }_{\mathrm{N} 1} \ldots$

\section{Redação 02}

Não há

\section{$\underline{\text { Redação } 03}$}

(31) qualdo estiver acabando o dinheiro, $[\theta]_{\mathrm{N} 0}$ peso para ele ${ }_{\mathrm{N} 2} \operatorname{voltar}_{\mathrm{N} 1} \ldots$

\section{Redação 04}

não há

\section{Redaç̃̃o 05}

(32) Já chegou ele ${ }_{\mathrm{N} 0}$ falou $[\theta]_{\mathrm{N} 2}$ que o cara não precisava esperar ${ }_{\mathrm{N} 1} \ldots$

(33) derrepente uma mão fria apertou o ombro e $[\theta]_{\mathrm{N} 0}$ fala $[\theta]_{\mathrm{N} 2}$ você está perdido ${ }_{\mathrm{N} 1}$

\section{Redação 06}

(34) Certo dia o Luís $\mathrm{N}_{\mathrm{N} 0}$ não aguento mas e falou $[\theta]_{\mathrm{N} 2}$, Eí garoto você $\hat{\mathrm{N}}_{1}$.

(35) o Otávio No não deu bola ${ }_{\mathrm{N} 1}$ para ele $_{\mathrm{N} 2}$

(36) Pagou o motorista com 19 reais e $[\theta]_{\mathrm{N} 0}$ falou $[\theta]_{\mathrm{N} 2}$ que levava o restante do dinheiro $\operatorname{amanhan}_{\mathrm{N} 2}$ 
(37) ...o Luís $\mathrm{N}_{\mathrm{N} 0}$ falou $[\theta]_{\mathrm{N} 2}$ como entrei tanto assustado ${ }_{\mathrm{N} 1} \ldots$

(38) Otávio ${ }_{\mathrm{N} 0}$ se aproximou e falou para o Luís ${ }_{\mathrm{N} 2}$, garoto temos que $\mathrm{ir}_{\mathrm{N} 1}$.

(39) Ele $_{\mathrm{N} 0}$ falou $[\theta]_{\mathrm{N} 1}$ para a mãe dele ${ }_{\mathrm{N} 2}$

\section{Redaç̃̃o 07.}

(40) de manhã vinha uma moça ${ }_{\mathrm{N} 0}$ trazer comida ${ }_{\mathrm{N} 1}$ para ele $_{\mathrm{N} 2}$.

(41) o menino ${ }_{\mathrm{N} 0}$ tinha 19 reais então deu $[\theta]_{\mathrm{N} 2}$ o dinheiro ${ }_{\mathrm{N} 1}$ que ele tinha

(42) e $[\theta]_{\mathrm{N} 0}$ falou para o taxista $[\theta]_{\mathrm{N} 2}$ que iria pagar outro dia ${ }_{\mathrm{N} 1}$

\section{$\underline{\text { Redação } 08}$}

(43) ...um menino chamado Otávio que como eu ${ }_{\mathrm{N} 0}$ disse $[\theta]_{\mathrm{N} 2}$ ou estava no telhado ou entrado em um perua ${ }_{N 1} \ldots$

(44) Ele $_{\mathrm{N} 0}$ pegou suas economias e pagou um taxi e disse pro motorista

- Siga essa piruá.N1

(45) $\mathrm{E}$ o homem $\mathrm{N}$ com uma cara desconfiada e sem dizer $[\theta]_{\mathrm{N} 2}$ nada $_{\mathrm{N} 1}$ deu a partida

OI anafórico de $3^{\mathrm{a}}$ pessoa nulo

(46) e o menino ${ }_{\mathrm{N} 0}$ disse ao motorista ${ }_{\mathrm{N} 2}$ :

- Amanhã eu lhe pago sem falta, ok ${ }_{\mathrm{N} 1}$

(47) ...e antes que o menino saise o homem No disse $[\theta]_{\mathrm{N} 2}$ :

- Cuidado menino ${ }_{N 1} \ldots$

(48) ...e o menino ${ }_{\mathrm{N} 0}$ disse $[\theta]_{\mathrm{N} 2}$ :

- Não se preocupe é um trabalho de escola 1 


\section{Redacão 09.}

Não há

\section{Redação 10.}

(49) Ao chegar em casa a mãe $\mathrm{N}_{\mathrm{N} 0}$ explicou $[\theta]_{\mathrm{N} 2}[\theta]_{\mathrm{N} 1}$

(50) ...e $[\theta]_{\mathrm{N} 0}$ disse $[\theta]_{\mathrm{N} 2}$ que o seu vizinho Otavio foi encontrado quando era um bebê $\hat{\mathrm{N}}_{1} \ldots$

\section{$7^{0}$ ano Escola Particular}

\section{$\underline{\text { Redação } 01}$}

(51) ...então o detetive foi até ele e [o detetive $]_{\mathrm{N} 0}$ perguntou $[\theta]_{\mathrm{N} 2}$ se ele sabia de algo sobre a morte do escritor...N1

(52) e ele gritou: "fui eu", então imediatamente ligou para polícia e [ele $]_{\mathrm{N} 0}$ disse $[\theta]_{\mathrm{N} 2}$ pela primeira vez: "Resolvi o caso".N1

\section{Redaç̃̃o 02}

Não tem

\section{Redação 03}

(53) ...tocou a campainha e um homem abriu a porta, que por acaso não tinha uma aparência boa. $[\mathrm{Eu}]_{\mathrm{N} 0}$ Disse $[\theta]_{\mathrm{N} 2}$ que eu era detetive e se podia fazer umas perguntas...N1

(54) $\ldots[\text { ele }]_{\mathrm{N} 0}$ respondeu $[\theta]_{\mathrm{N} 2}$ que $\operatorname{sim}_{\mathrm{N} 1}$, sentamos no sofá,

(55) $\quad . .[\mathrm{eu}]_{\mathrm{N} 0}$ perguntei a ele $\underline{\mathrm{N} 2}_{2}$ se esteve na casa do escritor falecido ${ }_{\mathrm{N} 1}$

(56) $\quad \ldots[\mathrm{eu}]_{\mathrm{N} 0}$ disse $[\theta]_{\mathrm{N} 2}$ que $\operatorname{sim}_{\mathrm{N} 1}$, me explicou que era amigo dele ...

\section{Redaç̃̃o 04}


(57) ..até que uma hora que o ladrão tocou no ombro do escritor e [o ladrão $]_{\mathrm{N} 0}$ disse $[\theta]_{\mathrm{N} 2}$ :

- Eu quero comer.N1

(58) ...então foram até o ladrão e [eles $]_{\mathrm{N} 0}$ disseram $[\theta]_{\mathrm{N} 2}$ :

- Acorde, você está preso! 1

\section{Redação 05}

(59) O escritor estava apavorado e [o escritor $]_{\mathrm{N} 0}$ não sabia o que dizer $[\theta]_{\mathrm{N} 2}$.

- Na...não faça nada comigo...N1

(60) ...po-por favor $_{\mathrm{N} 1}-$ Disse $[\theta]_{\mathrm{N} 2}$ o escritos eno $_{\mathrm{N} 0}$ tropeçando nas próprias palavras.

(61) - Eu quero comer! $!_{\mathrm{N} 1}-$ Disse $[\theta]_{\mathrm{N} 2}$ o homem ${ }_{\mathrm{N} 0}$ com mais firmeza na voz.

(62) Sem pensar mais um pouco, pegou o prato e $[\mathrm{ele}]_{\mathrm{N} 0}$ deu $[\theta]_{\mathrm{N} 1}$ ao homem ${ }_{\mathrm{N} 2}$ faminto, que devorou os sanduiches.

- Ainda estou com muita fome!

(63) - Minha nossa senhora! $!_{\mathrm{N} 1}-$ disse $[\theta]_{\mathrm{N} 2}$ o escritor ${ }_{\mathrm{N} 0}$ se arrependendo do que falou.

(64) - Espera que eu já venho! - Pegou sua cesta de frutas e [ele $]_{\mathrm{N} 0}$ entregou $[\theta]_{\mathrm{N} 1} \underline{\text { à ele }}_{\mathrm{N} 2}$.

(65) - É, dá pro gasto! $!_{\mathrm{N} 1}-[\text { Ele }]_{\mathrm{N} 0}$ Disse $[Q]_{\mathrm{N} 2}$ já colocando tudo na boca...

(66) ...e [ele $]_{\mathrm{N} 0}$ perguntou $[\theta]_{\mathrm{N} 2}-$ Bom, o que você estava fazendo, para tomar um susto tão grande? $?_{\mathrm{N} 1}$

\section{$\underline{\text { Redação } 06}$}

(67) ...quando acordou [ele $]_{\mathrm{N} 0}$ ficou falando para os médicos ${ }_{\mathrm{N} 2}$ que tinha visto o escritor.1

(68) E Jeff ${ }_{\mathrm{N} 0}$ contou $[\theta]_{\mathrm{N} 2}$ também que o escritor gritava com ele $\mathrm{N}_{\mathrm{N} 1} \ldots$ 


\section{$\underline{\text { Redacão } 07}$}

(69) O corpo foi mandado para o necrotério e lá os especialistas $\mathrm{N}_{\mathrm{N} 0}$ disseram $[\theta]_{\mathrm{N} 2}$ que o escritor não estava morto $\mathrm{N}_{1}$ só tinha levado um susto, e agora ele vai ser encaminhado para um hospital

\section{Redaç̃o 08}

Não há

\section{$\underline{\text { Redação } 09}$}

(70) Jeff Thomas relembrou da história que a empregada $a_{\mathrm{N} 0}$ contou $[\theta]_{\mathrm{N} 2}$, que seu patrão escrevia histórias de terror e tinha problema no coração ${ }_{\mathrm{N} 1}$.

(71) Atraz do vento entrou um mendigo em direção ao dono da casa e [o mendigo $]_{\mathrm{N} 0}$ disse $[\theta]_{\mathrm{N} 2}$ com a voz rouca:

$\mathrm{Eu}$ quero comer. ${ }_{\mathrm{N} 1}$

\section{Redacão 10}

(72) Depois do enterro do escritor Jeff com o relatório na mão leu outra vez a pequena história do escritor e lembrou que a empregada ${ }_{\mathrm{N} 0}$ disse $[\theta]_{\mathrm{N} 2}$ que tinha deixado um prato de sanduiches em cima da mesa...N1

\section{$7^{0}$ ano Escola Pública}

\section{$\underline{\text { Redação 01 }}$}

(73) Ele tem uma namorada chamada Mariana uma linda moça, mas Lucas ${ }_{N 0}$ não conseguia fala para ela ${ }_{\mathrm{N} 2}$ que ele ama ela $\mathrm{N}_{1}$.

(74) ...quando ele $\mathrm{N}_{\mathrm{N} 0}$ conseguia fala algun $\mathrm{N}_{\mathrm{N} 1}$ para ela $\mathrm{N}_{\mathrm{N} 2}$ so saião lagrimas.

(75) Mas Lucas não conseguia e não [Lucas] $]_{\mathrm{N} 0}$ queria falar para Mariana ${ }_{\mathrm{N} 2}$ que ele ia ir. .N1 
(76) e [ele $]_{\mathrm{N} 0}$ disse para o Normilsom ${ }_{\mathrm{N} 2}$ o seu irmão "cuida de tudo, agora tu e o hominho da casa".N1

(77) ...o homem ho $_{\mathrm{N} 0}$ perguntou para ele ${ }_{\mathrm{N} 2}$, o que você achava de São Paulo ${ }_{\mathrm{N} 1}$

(78) Lucas $_{\mathrm{N} 0}$ não sabia o que $\mathrm{N}_{\mathrm{N}}$ dizer a ele $\underline{\mathrm{N}}_{2}$

(79) ...sua mãe $e_{\mathrm{N} 0}$ falou $[\theta]_{\mathrm{N} 2}$ que ela queria o seu endereço $\mathrm{N}_{\mathrm{N} 1}$

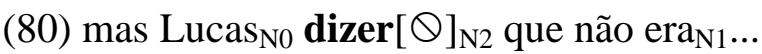

(81) ...não era para $[\theta]_{\mathrm{N} 0}$ dar o endereço ${ }_{\mathrm{N} 1}$ para ela ${ }_{\mathrm{N} 2}$

(82) $\quad \ldots$ ele $e_{\mathrm{N} 0}$ perguntou $[\theta]_{\mathrm{N} 2}$ o que você está fazendo aqui $i_{\mathrm{N} 1} \ldots$

(83) $\quad .$. ela $_{\mathrm{N} 0} \operatorname{dizer}[\theta]_{\mathrm{N} 2}$ :

- Eu vir atrás de você Lucas $_{\mathrm{N} 1}$

(84) Lucas $_{\mathrm{N} 0}$ conseguiu fala todo o que ele sentia ${ }_{\mathrm{N} 1}$ para Mariana ${ }_{\mathrm{N} 2}$

\section{Redacão 02}

(85) ...mas o jovem rapaz $\mathrm{N}_{\mathrm{N}}$ não conseguia falar sobre o discurso que preparou $\mathrm{N}_{1}$ para a namorada $\mathrm{N} 2$

(86) - Você quem é filho de José, Lucas? $?_{\mathrm{N} 1} \operatorname{Dizia}[\theta]_{\mathrm{N} 2}$ um homem estranho ${ }_{\mathrm{N} 0}$, chamado Tonhão

(87) E derrepente uma $\operatorname{voz}_{\mathrm{N} 0} \operatorname{diz}[\theta]_{\mathrm{N} 2}$ :

- Quanto tempo, te procuro.N1

(88) Mariana $_{\mathrm{N} 0}, \operatorname{contou}[\theta]_{\mathrm{N} 2}$ :

- Minha tia veio a São Paulo, e eu vim com ela ${ }_{\mathrm{N} 1}$. 


\section{$\underline{\text { Redação } 03}$}

(89) Quando Lucas $_{\mathrm{N} 0} \operatorname{contou}[\theta]_{\mathrm{N} 2}$ que teria que ir embora para São Paulo ${ }_{\mathrm{N} 1}$

(90) Lucas $_{\mathrm{N} 0}$ desconfortável com aquela situação disse $[\theta]_{\mathrm{N} 2}$ "adeus" ${ }_{\mathrm{N} 1}$ e foi embora.

(91) ...com um homem estranho, baixinho e gorducho ${ }_{\mathrm{N} 0}$, que $\underline{\text { lhe }}_{\mathrm{N} 2}$ perguntou se era filho de José $_{\mathrm{N} 1 \cdots}$

(92) e ele mexeu a cabeça e $[\text { ele }]_{\mathrm{N} 0}$ disse $[\theta]_{\mathrm{N} 2} \operatorname{sim}_{\mathrm{N} 1}$

(93) Ele $_{\mathrm{N} 0} \underline{\text { he }}_{\mathrm{N} 2}$ indicou o caminho ${ }_{\mathrm{N} 1}$ para sua mercearia...

(94) o senhor $_{\mathrm{N} 0}$ indicou $[\theta]_{\mathrm{N} 2}$ o quarto ${ }_{\mathrm{N} 1}$ onde seu pai estava

(95) Os dois se olharam, e logo depois José ${ }_{\mathrm{N} 0} \operatorname{disse}[\theta]_{\mathrm{N} 2}$ :

- Filho a vida tá difícil $1_{\mathrm{N} 1 \ldots}$

(96) ...por um salário medíocre, que [Lucas $]_{\mathrm{N} 0}$ mandava quase todo ${ }_{\mathrm{N} 1}$ para sua mãe ${ }_{\mathrm{N} 2}$.

(97) Tonhão ${ }_{\mathrm{N} 0}$ o explorava e ainda dizia $[\theta]_{\mathrm{N} 2}$ que não era malandro ${ }_{\mathrm{N} 1}$

(98) recebeu um telegrama de sua mãe ${ }_{\mathrm{N} 0}$ que dizia $[\theta]_{\mathrm{N} 2}$ que Mariana queria seu endereço $\mathrm{N} 1 \cdots$

(99) Mariana $\mathrm{N} 0_{0}$ queria seu endereço para $\underline{\text { he }}_{\mathrm{N} 2}$ escrever $[\theta]_{\mathrm{N} 1} \ldots$

(100) Tonhão $\mathrm{N}_{\mathrm{N} 0}$ tinha $\underline{\text { lhe }}_{\mathrm{N} 2}$ dado um bolo de dinheiro ${ }_{\mathrm{N} 1}$.

(101) ...a primeira coisa que $[\text { Mariana }]_{\mathrm{N} 0}$ disse $[\theta]_{\mathrm{N} 2}$ foi:

- Você não sabe o que eu fiz...N1

(102) Lucas olhou para ela chorando e $[\text { Lucas }]_{\mathrm{N} 0}$ falou $[\theta]_{\mathrm{N} 2}$ : 
- Mariana, eu te $a m o !_{\mathrm{N} 1}$

\section{Redação 04}

(103) Lucas $_{\mathrm{N} 0}$ não podia dizer $[\theta]_{\mathrm{N} 2}$ isso ${ }_{\mathrm{N} 1}$ com palavras...

(104) Lucas $_{\mathrm{N} 0}$ não conseguia dizer a Mariana o quanto a amava $\mathrm{N}_{\mathrm{N} 1}$.

(105) Lucas abriu seu coração e [Lucas $]_{\mathrm{N} 0}$ começou a falar a verdade $\mathrm{N}_{1} \underline{\text { a Mariana.N2 }}$

(106) ...logo mariana começou a ficar triste e $[\text { Mariana }]_{\mathrm{N} 0}$ começou a falar $[\theta]_{\mathrm{N} 2}$ : Então tu nunca gostou de $\operatorname{mim}_{\mathrm{N} 1}$.

(107) o homem gorducho que seu pai $i_{\mathrm{N} 0}$ havia dito $[\theta]_{\mathrm{N} 2}$ que era o patrão $\mathrm{N}_{\mathrm{N} 1}$.

(108) ...o patrão $\mathrm{N}_{\mathrm{N} 0}$ explicou[$[\Theta]_{\mathrm{N} 2}$ : o demônio havia botado tentação $\mathrm{N}_{\mathrm{N} 1} \ldots$

(109) O demônio ${ }_{\mathrm{N} 0}$ havia botado tentação $\mathrm{N}_{\mathrm{N} 1}$ para ele $_{\mathrm{N} 2}$

(110) O Pai de $\operatorname{Lucas}_{\mathrm{N} 0}$ havia explicado $[\theta]_{\mathrm{N} 2}$ que, por esse motivo não poderia trabalhar ${ }_{\mathrm{N} 1}$.

(111) ...e [o pai de Lucas $]_{\mathrm{N} 0}$ tinha que enviar dinheiro ${ }_{\mathrm{N} 1}$ para sua mulher ${ }_{\mathrm{N} 2}$.

(112) ...então [o pai $]_{\mathrm{N} 0}$ pediu para o filho ${ }_{\mathrm{N} 2}$ viajar até São Paulo ${ }_{\mathrm{N} 1} \ldots$

(113) ...e [Lucas] $]_{\mathrm{N} 0}$ perguntou a ela ${ }_{\mathrm{N} 2}$, o que você tá fazendo aqui, em São Paulo ${ }_{\mathrm{N} 1}$.

(114) ...e $\operatorname{Lucas}_{\mathrm{N} 0}$ finalmente disse $[\theta]_{\mathrm{N} 2}$ que a amava $a_{\mathrm{N} 1} \ldots$

(115) ...e ela $\mathrm{N}_{\mathrm{N} 0}$ disse $[\theta]_{\mathrm{N} 2}$ a mesma coisa ${ }_{\mathrm{N} 1} \ldots$

(116) ...[Lucas $]_{\mathrm{N} 0}$ deu adeus N1 $\underline{\text { ao pai }}_{\mathrm{N} 2 \ldots}$ 


\section{$\underline{\text { Redação } 05}$}

(117) ...ele tentou ficou ensaiando um discurso ${ }_{\mathrm{N} 1}$ para [Lucas $]_{\mathrm{N} 0}$ falar a ela $\underline{\mathrm{N}}_{2}$

(118) Lucas $_{\mathrm{N} 0}$ não queria falar $[\theta]_{\mathrm{N} 2}$ so isso $_{\mathrm{N} 1}$

(119) ...[Lucas $]_{\mathrm{N} 0}$ queria dizer $\underline{\text { a ela }}{ }_{\mathrm{N} 2}$ seu $\operatorname{amor}_{\mathrm{N} 1}$

(120) ...ele $e_{\mathrm{N} 0}$ fala para seu irmão mais novo Normilsom ${ }_{\mathrm{N} 2}$ "agora tu é o hominho da casa" ${ }_{\mathrm{N} 1} \ldots$.

(121) ...e lucas partiu sem mesmo [Lucas] $]_{\mathrm{N} 0}$ dizer tchau ${ }_{\mathrm{N} 1}$ ! ao amor da sua vida ${ }_{\mathrm{N} 2}$.

(122) Lucas encontra um cara gordo e baixu $\mathrm{N}_{\mathrm{N} 0}$ dizendo $[\theta]_{\mathrm{N} 2}$ : que era amigo de josé $e_{\mathrm{N} 1}$.

(123) $\mathrm{O}$ estranho $_{\mathrm{N} 0}$ deu $\underline{\text { he }}_{\mathrm{N} 2}$ uns tapinhas nas $\operatorname{costas}_{\mathrm{N} 1}$ de Lucas

\section{$\underline{\text { Redação } 06}$}

(124) ...certa vez ele encontrou Mariana na praça e [Lucas $]_{\mathrm{N} 0}$ disse a ela $\underline{\mathrm{N}}_{2}$ que o pai dele arrumou um emprego $\mathrm{N}_{\mathrm{N} 1} \ldots$

(125) ...o pai dele $\mathrm{N}_{\mathrm{N} 0}$ arrumou um emprego $\mathrm{O}_{\mathrm{N} 1}$ para ele $_{\mathrm{N} 2}$ em São Paulo.

(126) Mariana fica triste e [Mariana $]_{\mathrm{N} 0}$ pergunta para ele ${ }_{\mathrm{N} 2}$ se ele não a ama mais ${ }_{\mathrm{N} 1}$.

(127) $\operatorname{Luca}_{\mathrm{N} 0} \operatorname{diz}[\theta]_{\mathrm{N} 2}$ que não $\mathrm{N}_{1} \ldots$

\section{$\underline{\text { Redação } 07}$}

(128) ....mas [Lucas $]_{\mathrm{N} 0}$ não sabia como dizer isso ${ }_{\mathrm{N} 1} \underline{\text { a Mariana }}_{\mathrm{N} 2}$ (seu grande amor).

(129) ...porque $[\text { Lucas }]_{\mathrm{N} 0}$ não queria $\operatorname{dizer}[\theta]_{\mathrm{N} 2} \operatorname{adeus}_{\mathrm{N} 1}$. 
$(130) \ldots$... $[\text { Lucas }]_{\mathrm{N} 0}$ disse $[Q]_{\mathrm{N} 2}$ que ia embora pra São Paulo ${ }_{\mathrm{N} 1}$

(131) Mariana ${ }_{\mathrm{N} 0}$ falou $[\theta]_{\mathrm{N} 2}$ que ia sentir muito sua falta $\mathrm{N}_{\mathrm{N} 1}$.

(132) $\operatorname{Lucas}_{\mathrm{N} 0}$ queria dizer $[\theta]_{\mathrm{N} 2} \mathrm{o}$ amor que tinha por Mariana $\mathrm{N} 1_{1} \ldots$

(133) Ele $_{\mathrm{N} 0}$ disse $[\theta]_{\mathrm{N} 2}$ que ia para São Paulo ${ }_{\mathrm{N} 1}$

(134) ...e $[\text { Mariana }]_{\mathrm{N} 0}$ disse $[\theta]_{\mathrm{N} 2}$ que era injusto ${ }_{\mathrm{N} 1}$.

(135) Ele $_{\mathrm{N} 0} \underline{\text { lhe }}_{\mathrm{N} 2}$ indicou o caminho $\mathrm{N}_{1} \ldots$

(136) Tonhão $\mathrm{N}_{\mathrm{N} 0}$ falou para $\mathrm{LucaS}_{\mathrm{N} 2}$ que seu pai tinha levado um tiro em uma briga $\mathrm{N}_{\mathrm{N}}$.

(137) Tonhão ${ }_{\mathrm{N} 0}$ disse $[\theta]_{\mathrm{N} 2}$ que o pai dele tinha uma grande conta $\mathrm{N}_{\mathrm{N} 1}$

(138) então ela $\mathrm{N}_{\mathrm{N} 0}$ explica $[\theta]_{\mathrm{N} 2}$ que sua tia ia vi para São Paulo ${ }_{\mathrm{N} 1}$

\section{Redaç̃o 08}

(139) ...que quase não teve palavras para $[\text { Lucas }]_{\mathrm{N} 0}$ explicar $[\theta]_{\mathrm{N} 2}$ o porque partir para trabalhar numa cidade desconhecida $\mathrm{N}_{1}$.

(140) ...para sua mainha $\mathrm{p}_{\mathrm{N} 0} \underline{\text { lhe }}_{\mathrm{N} 2}$ dar o endereço de onde Lucas estava $\mathrm{N}_{1}$ e foi...

(141) $\ldots[\text { Lucas }]_{\mathrm{N} 0}$ dar- $\underline{\text { he }}_{\mathrm{N} 2}$ o seguinte recado ${ }_{\mathrm{N} 1}$.

\section{Redaç̃̃o 09}

(142) por ela [Lucas $]_{\mathrm{N} 0}$ começava a dizer $[\theta]_{\mathrm{N} 2}$ outras $\operatorname{coisas}_{\mathrm{N} 1}$

(143) $\operatorname{coisas}_{\mathrm{N} 1}$ que pela primeira vez [Lucas $]_{\mathrm{N} 0}$ conseguia dizer $[\theta]_{\mathrm{N} 2}$ sem medo de tropeçar OI anafórico de $3^{\mathrm{a}}$ pessoa nulo 
(144) então ele $e_{\mathrm{N} 0}$ começou a falar $[\theta]_{\mathrm{N} 2}$ que iria embora ${ }_{\mathrm{N} 1}$

(145) então [Mariana $]_{\mathrm{N} 0}$ perguntou para Lucas ${ }_{\mathrm{N} 2}$ que se ele ainda a a amava $\mathrm{N}_{\mathrm{N} 1}$

(146) ...o estranho $\mathrm{N}_{\mathrm{N} 0}$ deu $[\theta]_{\mathrm{N} 2}$ uns tapinhas nas $\operatorname{costas}_{\mathrm{N} 1}$

(147) ...e [o estranho $]_{\mathrm{N} 0}$ indicou[ $[\theta]_{\mathrm{N} 2}$ com o braço a direção de que Lucas deveria ir.

(148) ...o pai N0 $_{\text {perguntou para Tonhão }}$ N2 se tinha trabalhoN1

(149) Tonhão ${ }_{\mathrm{N} 0}$ perguntou para Lucas ${ }_{\mathrm{N} 2}$ se ele tinha sertidão de nascimento ${ }_{\mathrm{N} 1} \ldots$

\section{Redação 10}

(150) Mariana era a garota que ele amava $\mathrm{N}_{\mathrm{N} 1}$ mais $[\text { Lucas }]_{\mathrm{N} 0}$ não tinha coragem de $\operatorname{dizer}[\theta]_{\mathrm{N} 2}$.

(151) ...e $[\text { Lucas }]_{\mathrm{N} 0}$ disse $[Q]_{\mathrm{N} 2}$ que teria que $\operatorname{viajar}_{\mathrm{N} 1} \ldots$

(152) $\quad . .$. ele $_{\mathrm{N} 0}$ só conseguia dizer $[\theta]_{\mathrm{N} 2}$ um “Adeus” ${ }_{\mathrm{N} 1}$

(153) Mariana chorava porque ele $\mathrm{N}_{\mathrm{N} 0}$ não tinha coragem de dizer $[\theta]_{\mathrm{N} 2}$ um simples "Eu te amo" 1

(154) pagar as dispesas ${ }_{\mathrm{N} 1}$ que seu pai ${ }_{\mathrm{N} 0}$ deu pra Tonhão ${ }_{\mathrm{N} 2}$

(155) $[\text { Lucas }]_{\mathrm{N} 0}$ mandava $[\theta]_{\mathrm{N} 1}$ pra sua mãe

(156) ...quando caiu a fica $[\text { Lucas }]_{\mathrm{N} 0}$ começou a dizer $[\theta]_{\mathrm{N} 2}$ : "Eu te amo" ${ }_{\mathrm{N} 1}$

(157) Lucas resolveu ir embora pro Nordeste $[\text { Lucas }]_{\mathrm{N} 0} \operatorname{contou}[\theta]_{\mathrm{N} 1}$ para Tonhão ${ }_{\mathrm{N} 2}$

$(158)[\text { Lucas }]_{\mathrm{N} 0}$ disse $[\theta]_{\mathrm{N} 2}$ que era muito novo $_{\mathrm{N} 1}$ 


\section{$8^{\circ}$ ano Escola Particular}

\section{$\underline{\text { Redacão } 1}$}

(159) Desde a catástrofe, o imperador ${ }_{\mathrm{N} 0}$ ordenou aos seus súditos ${ }_{\mathrm{N} 2}$ que explorassem o infinito $_{\mathrm{N} 1} \cdots$

(160) Ela $_{\mathrm{N} 0}$ explicou $[\theta]_{\mathrm{N} 2}$ que se destruísse o planeta $\mathrm{N}_{\mathrm{N} 1}$ e o seu povo inútil poderia recomeçar a povoação do zero se tornaria a imperadora

(161) - Você sempre teve mania de grandeza 1

Disse $[\theta]_{\mathrm{N} 2}$ Melvin $_{\mathrm{N} 0}$

\section{$\underline{\text { Redaç̃o } 2}$}

(162) ...então ela $\mathrm{N}_{\mathrm{N} 0}$ falou para seus pais $\mathrm{N}_{\mathrm{N} 2}$ marcarem sua festa $\mathrm{N}_{\mathrm{N} 1}$

(163) e seu pai ${ }_{\mathrm{N} 0}$ disse $[\theta]_{\mathrm{N} 2}$ :

- Mas filha como você vai conseguir arrumar 15 casais na última hora ${ }_{\mathrm{N} 1}$

(164) No dia seguinte na escola, ela convidou suas amigas e elas ${ }_{\mathrm{N} 0}$ disseram $[\theta]_{\mathrm{N} 2}$ :

- Que dia vai ser Náthally? $?_{\mathrm{N} 1}$

(165) Quando ela chegou em casa avisou aos seus pais que seus amigos tinham aceitado o seu convite de aniversário e seus pais ficaram muito feliz.

(166) E em uma bela manhã de sábado, Náthally $y_{\mathrm{N} 0}$ acordou falando $[\theta]_{\mathrm{N} 2}$ :

- Mãe hoje é meu aniversário! ${ }_{\mathrm{N} 1}$

(167) No dia seguinte ela $\mathrm{N}_{\mathrm{N} 0}$ falou para seus pais ${ }_{\mathrm{N} 2}$ :

- Pai, mãe eu amei ontem e eu não vou esquecer este momento nunca! ${ }_{\mathrm{N} 1}$ 


\section{$\underline{\text { Redação } 3}$}

(168) As estranhas criaturas o avistaram e ficaram observando por pelo menos uns dois minutos, sem dizer nada, até que o velho ${ }_{\mathrm{N} 0}$ disse $[\theta]_{\mathrm{N} 2}$ com a voz trêmula "Oque vocês querem na minha casa? Saiam!”1

(169) Uma das criaturas ${ }_{\mathrm{N} 0}$ disse $[\theta]_{\mathrm{N} 2}$ traduzindo a estranha língua em que falavam " $\mathrm{E}$ tragas sua lamparina" ${ }_{\mathrm{N} 1}$

(170) A criatura ${ }_{\mathrm{N} 0}$ disse $[\theta]_{\mathrm{N} 2}$ com calma "Tem certeza"? ${ }_{\mathrm{N} 1}$ e o velho assentiu com a cabeça, nervoso.

(171) A criatura $\mathrm{N}_{\mathrm{N} 0}$ perguntou $[\theta]_{\mathrm{N} 2}$ então mais uma vez "O senhor sabe onde encontrar Lívia de Anges?"N1

(172) “Qual o seu nome completo?" ${ }_{\mathrm{N} 1}$ disse $[\theta]_{\mathrm{N} 2}$ a criatura ${ }_{\mathrm{N} 0}$ começando a ficar irritada...

(173) A outra criatura ${ }_{\mathrm{N} 0}$ deu o chapéu $\mathrm{N}_{\mathrm{N} 1}$ para o colega $\mathrm{N}_{2}$ que colocou-o na cabeça do velho aflito

\section{$\underline{\text { Redacão } 4}$}

Não há

\section{$\underline{\text { Redacão } 5}$}

(174) $\operatorname{Todos}_{\mathrm{N} 0}$ dizem $[\theta]_{\mathrm{N} 2}$ que alienígenas são mais evoluídos que o ser humano que possuem máquinas inexistentes na Terra e que um dia poderiam nos transformar em escravos.N1

(175) Relatos ${ }_{\mathrm{N} 0}$ contavam $[\theta]_{\mathrm{N} 2}$ que seres não codificados realizavam de madrugada...N1

(176) $[\mathrm{Eu}]_{\mathrm{N} 0}$ Entreguei $\underline{\text { eles}}_{\mathrm{N} 2}$ um graveto ${ }_{\mathrm{N} 1}$.

\section{$\underline{\text { Redação } 6}$}


Não há

\section{$\underline{\text { Redacão } 7}$}

(177) Ele $_{\mathrm{N} 0}$ contava a seguinte história ${ }_{\mathrm{N} 1}$ para sua neta ${ }_{\mathrm{N} 2}$ :

(178) “Não tenha medo, estamos aqui para pedir sua ajuda" ${ }_{\mathrm{N} 1}-\operatorname{eles}_{\mathrm{N} 0}$ falavam $[\Theta]_{\mathrm{N} 2}$ por meio de um tradutor em seus cintos, e a essa hora eu estava apavorado.

(179) Então eu $\mathrm{N}_{0}$ disse $[\theta]_{\mathrm{N} 2}$ "Sim” ${ }_{\mathrm{N} 1}$

(180) - Vovô, da próxima vez que você for o senhor me leva? ${ }_{\mathrm{N} 1}-$ disse $[\theta]_{\mathrm{N} 2}$ sua netinha.N0

(181) - Claro que sim! Agora está na hora de você dormir. Boa noite $\mathrm{N}_{1}-$ disse $[\theta]_{\mathrm{N} 2}$ Vicente $_{\mathrm{N} 0}$, dando um beijo em sua testa.

(182) - Boa noite $\mathrm{N} 1-$ ela $_{\mathrm{N} 0}$ respondeu $[\theta]_{\mathrm{N} 2}$

\section{$\underline{\text { Redação } 8}$}

(183) - Wow, claro! ${ }_{\mathrm{N} 1}-\mathrm{eu}_{\mathrm{N} 0}$ disse $[\theta]_{\mathrm{N} 2}$ abraçando aquele baixinho era como...um sonho realizado.

(184) - Bom, já sei de muita coisa, mais do que você imagina Hagrid! $!_{\mathrm{N} 1}-[\mathrm{Eu}]_{\mathrm{N} 0}$ disse $[Q]_{\mathrm{N} 2}$ com brilho nos olhos.

\section{$\underline{\text { Redacão } 9}$}

(185) Quer saber, eu não tenho nada a perder, $[\mathrm{eu}]_{\mathrm{N} 0}$ vou falar para aqueles alienígenas $\mathrm{N}_{2}$ me levarem ao planeta deles $\mathrm{N}_{\mathrm{N} 1} \ldots$

(186) Dito e feito, o velho chamou os alienígenas apelidados de Harry e Jack, que sempre ouvia o velho com suas histórias, e $[\mathrm{ele}]_{\mathrm{N} 0}$ pediu $[\theta]_{\mathrm{N} 2}$ para os mandarem para seu planeta.N1 


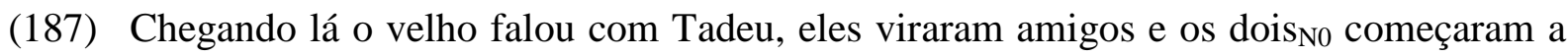
contar $[\theta]_{\mathrm{N} 2}$ suas histórias ${ }_{\mathrm{N} 1}$.

(188) $\operatorname{Tadeu}_{\mathrm{N} 0}$ contou $[\theta]_{\mathrm{N} 2}$ todas as dificuldades $\mathrm{N} 1_{\mathrm{N}}$ que passou,como fome.

(189) Ao final dessa confusão toda, o velho foi conversar com seus amigos Harry e Jack, que também [eles $]_{\mathrm{N} 0}$ contaram $[\theta]_{\mathrm{N} 2}$ sua história ${ }_{\mathrm{N} 1}$.

(190) Os gêmeos ${ }_{\mathrm{N} 0}$ perguntaram $[\theta]_{\mathrm{N} 2}$ o nome do velho ${ }_{\mathrm{N} 1}$,

(191) $\ldots$ e ele $e_{\mathrm{N} 0}$ respondeu $[\theta]_{\mathrm{N} 2}$, Valorização $\mathrm{N}_{\mathrm{N} 1}$.

\section{$8^{\circ}$ ano Escola Pública}

\section{$\underline{\text { Redação } 1}$}

(192) Na festa ofereceram droga a ela,

\section{Redação 2}

(193) Mas o fundo do poço dela foi quando ela pegou AIDS, mas ela $a_{\mathrm{N} 0}$ pediu $[\theta]_{\mathrm{N} 2}$ ajuda $_{\mathrm{N} 1}$ e foi para o hospital.

(194) Ela $_{\mathrm{N} 0}$ pediu ajuda ${ }_{\mathrm{N} 1}$ para sua enfermeira ${ }_{\mathrm{N} 2}$ e amiga Dani para escrever a carta.

(195) $\quad . . . e l a_{\mathrm{N} 0}$ pede $[\theta]_{\mathrm{N} 2}$ que nenhum jovem esperimente drogas $_{\mathrm{N} 1}$

\section{$\underline{\text { Redação } 3}$}

(196) ...fez novos amigos e $[\text { nós }]_{\mathrm{N} 0}$ vamos dizer $[\theta]_{\mathrm{N} 2}$ que amios né 1 ??

(197) Depois ela começa a se prostituir com os velhos ${ }_{\mathrm{N} 0}$ que dão $[\theta]_{\mathrm{N} 2}$ muito dinheiro ${ }_{\mathrm{N} 1}$ e aí ela pega o vírus da aids. 


\section{$\underline{\text { Redação } 4}$}

(198) Então $[\mathrm{eu}]_{\mathrm{N} 0}$ comecei a dizer $[\theta]_{\mathrm{N} 2}$ que tudo estava perdido $\mathrm{N}_{\mathrm{N} 1}$ e quando eu menos esperava algum

\section{$\underline{\text { Redacão } 5}$}

(199) Eu e meu irmão hoje estamos muito felizes, e [nós $]_{\mathrm{N} 0}$ demos o nome $\mathrm{N}_{1}$ para o nosso $\underline{\text { cachorro }}_{\mathrm{N} 2}$ de Lancelote

\section{$\underline{\text { Redação } 6}$}

(200) ...ela estava atrás de mim e me perguntou o que eu estava fazendo ali e eu $u_{\mathrm{N} 0}$ respondi $[Q]_{\mathrm{N} 2}$ que saímos mais cedo $\mathrm{N} 1_{\mathrm{N}} \ldots$

(201) e logo depois que eu $\mathrm{N}_{\mathrm{N} 0}$ tinha dito $[\theta]_{\mathrm{N} 2}$ isso ${ }_{\mathrm{N} 1}$ o sinal bateu e o portão abriu,

(202) ai ela foi falar com a inspetora e a inspetora ${ }_{\mathrm{N} 0}$ disse $[\theta]_{\mathrm{N} 2}$ que teve aula normal $\mathrm{N}_{\mathrm{N} 1}$.

\section{Redaç̃o 6}

Não há

\section{$\underline{\text { Redação } 7}$}

(203) Essa é a história de um leiteiro, que acordava de madrugada para [o leiteiro $]_{\mathrm{N} 0}$ entregar o leite $\mathrm{N}_{1}$ para toda uma cidade $\mathrm{N}_{2}$, até nos lugares mais perigosos.

\section{Redacão 8}

Não há

\section{Redação 9}

Não há 


\section{Redação 10}

(204) Quando chegou a vez de Nafisi, seu pai ${ }_{\mathrm{N} 0}$ falou $[\theta]_{\mathrm{N} 2}$ :

- Nafisi, vá sozinha, pois confio muito em você.N1

\section{$9^{\circ}$ ano - Escola Particular}

\section{Redação 01}

(205) ...ajudei pessoas, $[\mathrm{eu}]_{\mathrm{N} 0}$ doei meus bens $\mathrm{N}_{\mathrm{N} 1}$ para as pessoas ${ }_{\mathrm{N} 2}$

(206) Procurei um padre, e $[\mathrm{eu}]_{\mathrm{N} 0}$ perguntei a ele ${ }_{\mathrm{N} 2}$.

(207) Na mesma hora ele $\mathrm{N}_{\mathrm{N} 0}$ respondeu $[\theta]_{\mathrm{N} 2}$

- Sim, o sacrifício 1

(208) $\mathrm{E}[\mathrm{eu}]_{\mathrm{N} 0}$ falei para o homem $\mathrm{N}_{2}$

- Tire minha vida em vez da dela 1

\section{Redaç̃o 02}

Não há

\section{$\underline{\text { Redação } 03}$}

(209) A mulher de Matusa ${ }_{\mathrm{N} 0}$ contou tudo ${ }_{\mathrm{N} 1} \underline{\text { há ela }}_{\mathrm{N} 2}$

\section{Redação 04}

(210) Eu a perdoei, mas $[\mathrm{eu}]_{\mathrm{N} 0}$ pedi $[\theta]_{\mathrm{N} 2}$ meu divórcio ${ }_{\mathrm{N} 1}$.

\section{Redaç̃̃o 05}

(211) $[\mathrm{Eu}]_{\mathrm{N} 0}$ Dei $[\theta]_{\mathrm{N} 2} 2$ tiros $_{\mathrm{N} 1}$ em cada uma

(212) $[\mathrm{Eu}]_{\mathrm{N} 0}$ Dei $[\theta]_{\mathrm{N} 2}$ um tiro ${ }_{\mathrm{N} 1}$ em seu joelho 


\section{Redacão 06}

Não há

\section{$\underline{\text { Redação } 07}$}

(213) $[\mathrm{Eu}]_{\mathrm{N} 0}$ Deveria pedir perdão $\mathrm{N}_{\mathrm{N} 1}$ para todos que eu magoei ${ }_{\mathrm{N} 2}$

\section{$\underline{\text { Redacão } 08}$}

(214) Ainda nervoso $[\mathrm{eu}]_{\mathrm{N} 0}$ disse $[\theta]_{\mathrm{N} 2}$ com a voz baixa e hesitante

- Si-si-sim. Do que precisa ${ }_{\mathrm{N} 1}$

(215) Logo apertei o passo $[\mathrm{eu}]_{\mathrm{N} 0}$ dizendo $[\theta]_{\mathrm{N} 2}$ :

- Estou indo...N1

(216) $[\mathrm{Eu}]_{\mathrm{N} 0} \operatorname{Disse}[\theta]_{\mathrm{N} 2}$ um alto e claro:

$-\operatorname{Sim}_{N 1}$

(217) - Sim Sr. Steven - disse $[\theta]_{\mathrm{N} 2}$ o chofer $_{\mathrm{N} 0}$

(218) $[\mathrm{Eu}]_{\mathrm{N} 0}$ Não mostrei $[\theta]_{\mathrm{N} 2}$ reação alguma no caminho ${ }_{\mathrm{N} 1}$

(219) Ela era uma amiga incrível, então $[\mathrm{eu}]_{\mathrm{N} 0}$ dei $[\theta]_{\mathrm{N} 2}$ um abraço bem apertado ${ }_{\mathrm{N} 1}$ enquanto escorriam lágrimas em meu rosto.

(220) Logo depois de sua saída peguei o telefone para ligar para a polícia. [Eu $]_{\mathrm{N} 0}$ Expliquei $[Q]_{\mathrm{N} 2} \operatorname{tudo}_{\mathrm{N} 1} \ldots$

(221) $[\mathrm{Eu}]_{\mathrm{N} 0}$ disse $[\theta]_{\mathrm{N} 2}$ que horas e em que lugar eu estaria com o desgraçado ${ }_{\mathrm{N} 1}$, com o futuro assassino.

(222) $[\mathrm{Eu}]_{\mathrm{N} 0}$ Pedi $[\theta]_{\mathrm{N} 2}$ que não fossem com aqueles carros ${ }_{\mathrm{N} 1} \ldots$ 


\section{Redação 09}

(223) Eu tive que $[\mathrm{eu}]_{\mathrm{N} 0}$ dar dinheiro $\mathrm{N}_{\mathrm{N}}$ para ele $\mathrm{N}_{\mathrm{N} 2} \ldots$

\section{$\underline{\text { Redação } 10}$}

(224) ...mas eu não consegui e amanhã $[\mathrm{eu}]_{\mathrm{N} 0}$ irei entregar $[\theta]_{\mathrm{N} 2}$ a minha velha alma $\mathrm{N}_{\mathrm{N} 1}$.

\section{$9^{\circ}$ ano - Escola Pública}

\section{Redação 01}

Não há

\section{Redacão 02}

Não há

\section{Redação 03}

(225) $[\mathrm{Eu}]_{\mathrm{N} 0}$ Disse aos meus pais $\underline{\mathrm{N}}_{2}$ que haveria o teste $\mathrm{N} 1_{\mathrm{N} 1} \ldots$

(226) Comecei a levar os cachorros do meus vizinhos para passear, [eu $]_{\mathrm{N} 0}$ pedir dinheiro ${ }_{\mathrm{N} 1}$ $\underline{\text { aos meus familiares }}_{\mathrm{N} 2}$ e enfim consegui

\section{$\underline{\text { Redação 04 }}$}

(227) Ana $_{\mathrm{N} 0}$ pediu para que $\underline{\text { ele }}_{\mathrm{N} 2}$ subisse $_{\mathrm{N} 1}$

(228) ...todas as lindas palavras que um dia sonhava em $[\mathrm{ela}]_{\mathrm{N} 0} \operatorname{dizer}[\theta]_{\mathrm{N} 1}$ para a linda $\underline{\operatorname{moça}}_{\mathrm{N} 2}$,

(229) $[$ Ele $]$ disse $[\theta]_{\mathrm{N} 2}$ [as lindas palavras $]_{\mathrm{N} 1}$ naquele momento.

\section{Redação 05}

Não há

\section{$\underline{\text { Redação } 06}$}


(230) Claro fiquei muito preocupado, pois se fosse demitido talvez não conseguisse [eu $]_{\mathrm{N} 0}$ dar $\underline{a ~ m i n h a ~ e s p o s a ~}_{\mathrm{N} 2}$ a tal vida tranquila que ela sempre sonhou $\mathrm{N}_{\mathrm{N}}$.

(231) ...[eu $]_{\mathrm{N} 0}$ fui dar a boa notícia $\mathrm{N}_{\mathrm{N} 1}$ a minha esposa ${ }_{\mathrm{N} 2}$.

\section{Redaç̃o 07}

Não há

\section{$\underline{\text { Redação } 08}$}

(232) Comovida, Sophia ${ }_{\mathrm{N} 0} \operatorname{diz}[\theta]_{\mathrm{N} 2}$ :

- Nossa, desculpe mãe,,.. $\mathrm{N} 1$

(233) $\mathrm{Eu}_{\mathrm{N} 0}$ prometo $[\theta]_{\mathrm{N} 2}$ que de agora em diante eu me esforçarei mais na escola $\mathrm{N}_{\mathrm{N}} \ldots$

\section{$\underline{\text { Redação } 09}$}

(234) ...até que um dia ela olhou para Josep e $[\text { ela }]_{\mathrm{N} 0}$ disse $[\theta]_{\mathrm{N} 2}$ :

- Chega dessa vida! $!_{\mathrm{N} 1}$

\section{$\underline{\text { Redação } 10}$}

Não há 